CARLA LONGO DE FREITAS

\title{
PROPRIEDADES IMUNOMODULADORAS DE CÉLULAS TRONCO MESENQUIMAIS ESTROMAIS NO MODELO DE ENCEFALOMIELITE EXPERIMENTAL AUTOIMUNE
}

Tese apresentada ao Programa de
Pós-graduação em Imunologia do
Instituto de Ciências Biomédicas da
Universidade de São Paulo para
obtenção do Título de Doutor em
Ciências.

São Paulo 
CARLA LONGO DE FREITAS

\title{
PROPRIEDADES IMUNOMODULADORAS DE CÉLULAS TRONCO MESENQUIMAIS ESTROMAIS NO MODELO DE ENCEFALOMIELITE EXPERIMENTAL AUTOIMUNE
}

\author{
Tese apresentada ao Programa de \\ Pós-graduação em Imunologia do \\ Instituto de Ciências Biomédicas da \\ Universidade de São Paulo para \\ obtenção do Título de Doutor em \\ Ciências.
}

Área de Concentração: Imunologia.

Orientador: Prof. Dr. Jean Pierre Schatzmann Peron.

Versão Original. 


\section{CATALOGAÇÃO NA PUBLICAÇÃO (CIP) \\ Serviço de Biblioteca e informação Biomédica do Instituto de Ciências Biomédicas da Universidade de São Paulo}

Ficha Catalográfica elaborada pelo(a) autor(a)

de Freitas, Carla Longo

PROPRIEDADES IMUNOMODULADORAS DE CÉLULAS TRONCO MESENQUIMAIS ESTROMAIS NO MODELO DE ENCEFALOMIELITE EXPERIMENTAL AUTOIMUNE / Carla Longo de Freitas; orientador Jean Pierre Schatzmann Peron. -- São Paulo, 2019 .

$93 \mathrm{p}$.

Tese (Doutorado)) -- Universidade de são Paulo, Instituto de Ciências Biomédicas.

1. Células tronco. 2. Autoimunidade. 3. Imunomodulação. 4. Encefalomielite Experimental Autoimune. I. Schatzmann Peron, Jean Pierre, orientador. II. Título. 


\section{UNIVERSIDADE DE SÃO PAULO \\ INSTITUTO DE CIÊNCIAS BIOMÉDICAS}

Candidato (a): Carla Longo de Freitas

Titulo da Dissertação/Tese: Propriedades Imunomoduladoras de Células Tronco Mesenquimais Estromais no Modelo de Encefalomielite Experimental Autoimune.

Orientador: Prof. Dr. Jean Pierre Schatzmann Peron

A Comissão Julgadora dos trabalhos de Defesa da Tese de Doutorado, em sessão pública realizada a ............................., considerou o(a) candidato(a):

\section{( ) Aprovado(a) ( ) Reprovado(a)}

Examinador (a): Assinatura:

Nome:

Instituição:

Examinador (a): Assinatura:

Nome:

Instituição:

Examinador (a): Assinatura:

Nome:

Instituição:

Presidente: Assinatura:

Nome:

Instituição: 


\section{Certificado}

Certificamos que a solicitação de licença de uso de animais intitulada Estudo do Perfil de miRNAs de Células Mesenquimais Estromais e de sua Função Imunomoduladora no Modelo de Encefalomielite Experimental Auto-imune, registrada sob no 011 , nas fls. 28, do livro 03, foi analisada e aprovada pela COMISSÃo DE ÉTICA NO USO DE ANIMAIS (CEUA-ICB/USP) em 30 de abril de 2015.

Por esta licença, estão autorizados a manipular animais dentro dos limites do projeto proposto e no âmbito da Lei Federal no 11.794, o Dr. (Dra.) Jean Pierre Schatzmann Peron (Investigador Principal) e os membros da equipe Carla Longo de Freitas, Cristiano Rossato e Wesley Nogueira Brandão. Esta licença de uso de animais expira em 30 / 04 / 2019.

Havendo interesse na renovação da proposta, a solicitação deverá ser protocolada pela secretaria da CEUAICB/USP até o último dia de validade da atual proposta. Após essa data, uma nova proposta deverá ser encaminhada.

\section{Certificate}

We hereby certify that permission for the use of animals was granted to the research proposal Study of the miRNA profile in strommal mesenchymal cells and their immunomodulatory function in the autoimmune experimental encephalomyelitis model, registered as Number 011 , in pages 28 of book 03 , by the local ETHICS COMMITTEE ON THE USE OF ANIMALS (CEUA-ICB/USP) in 04 / 30 / 2015.

Under this license, Jean Pierre Schatzmann Peron (Principal Investigator) and team members Carla Longo de Freitas, Cristiano Rossato and Wesley Nogueira Brandão are authorized to make use of animals within the limits of the research proposal presented to this committee and of the Brazilian Federal Law no 11.794.

This license expires in $04 / 30$ / 2019. In case the investigators wish to renew this license, this must be presented to CEUA-ICB/USP before the last day of validity of the present license. After such date, a new research proposal must be presented.

São Paulo, 30 de abril de 2015.
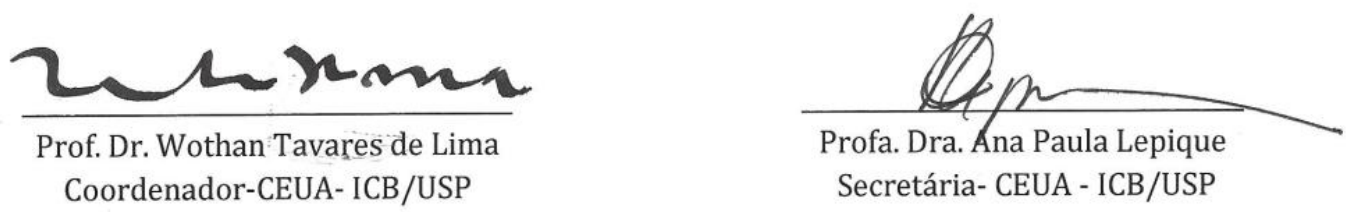


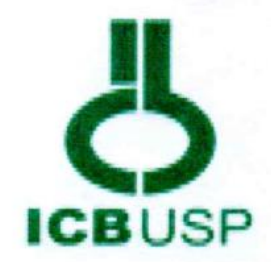

Cidade Universitária "Armando de Salles Oliveira", Butantă, São Paulo, SP - Av. Professor Lineu Prestes, 2415 - ICB III - 05508000 Comissăo de Ética no Uso de Animais - Telefone (11) 3091-7733 - e-mail: cep@icb.usp.br

Decl. CEUA.015.2019

\section{DECLARAÇÃo}

Em adendo ao Certificado 011/2015/CEUA, aprovado em 30/04/2015, e por solicitação do Prơf. Dr. Jean Pierre Schatzmann Peron, do departamento de Imunologia, informo que o título do projeto da aluna Carla Longo de Freitas foi alterado para "Propriedades Imonumoduladoras de Células Tronco Mesenquimais Estromais no Modelo de Encefalomielite Experimental Auto-imune" em decorrência de alterações no projeto, nas quais, a parte referente aos miRNAs não pode ser realizada.

São Paulo, 20 de fevereiro de 2019.

Luciane valéria Sita

Profa. Dra. Luciane Valéria Sita

Coordenadora CEUA-ICB/USP 
À Heloísa V. A. Caetano (in memorian) 


\section{AGRADECIMENTOS}

Agradeço imensamente ao meu orientador Prof. Jean Pierre Schatzmann Peron pela oportunidade de realizar meu doutorado e por ter me aceitado em seu grupo de pesquisa. $\mathrm{O}$ aprendizado e amadurecimento durante esses anos são imensuráveis.

Aos meus colegas de laboratório Wesley, Nagela, Lilian, Carolina e Claudinha por toda a ajuda na realização desse trabalho.

À Maria Eni e a todos os funcionários do ICB IV por todas as gentilezas.

Ao Dr. Danilo Candido por todo suporte científico.

À minha família querida e amada pelo suporte, apoio em todos os sentidos e, principalmente, pelo incentivo. Vocês são a minha base, minha fortaleza e meu porto seguro. Que sorte a minha ter vocês nessa jornada.

Ao Robert pelo companheirismo incondicional, por estar sempre ao meu lado me apoiando e pela família linda que iremos formar.

Aos queridos Eduardo e Angélica, por compartilharem e estarem presente no dia mais feliz da minha vida.

Às minhas grandes amigas Yuri, Bianca, Drica, Glauco, Soneca pela nossa amizade verdadeira que perdura há tantos anos e que perdure muito mais. Bons tempos de Unifesp!

Last but not least, I would like to thank Edgard, Marcelo, Sydney, Donna, Gareth, Stefan, Daniel, Alexander, Mydia, Audrey and Fabiano. I'm very glad for the crazy team we are. Thank you for trust me as an educator and the partnership so far.

Gratidão! 
"Nada é fixo, nada é permanente. A vida é isso, essa transitoriedade."

Cohen 


\section{RESUMO}

Freitas, C. L. Propriedades Imunomoduladoras de Células Tronco Mesenquimais Estromais no Modelo de Encefalomielite Experimental Autoimune. [Tese (Doutorado em Imunologia)]. São Paulo, Instituto de Ciências Biomédicas, Universidade de São Paulo; 2019.

A esclerose múltipla é uma doença degenerativa autoimune mediada por linfócitos $T$ auto-reativos a epítopos de mielina que se ativam inicialmente na periferia e infiltram o sistema nervoso central, levando à inflamação, e desmielinização. O modelo murino, Encefalomielite Experimental Autoimune, (EAE) tem sido usado para estudar os possíveis mecanismos envolvidos na esclerose múltipla. Células-tronco mesenquimais estromais são células multipotentes indiferenciadas que possuem propriedades imunomodulatórias. Tubas uterinas humanas denominadas htMSCs são uma fonte rica de células tronco mesenquimais estromais. Desta forma, como não há cura para a esclerose múltipla, nós propomos avaliar o efeito modulatório das htMSCs no modelo da EAE. Nossos resultados demonstram que o tratamento com htMSCs reduz a expressão das moléculas CD80, CD86 e MHC II no baço e linfonodo de células dendríticas dos animais tratados e aumenta a produção de IL-10. No pico da doença, os animais tratados apresentam score clínico reduzido. No sistema nervoso, observa-se diminuição de células infiltrantes e de microglia residente ativada. $\mathrm{O}$ tratamento com $h t M S C$ s reduziu a frequência e número absoluto das células Th1 (T CD4+IFN- $\left.\gamma^{+}\right)$e Th17 (T CD4+IL-17+) infiltrantes no cérebro. As medulas espinhais analisadas no pico e 30 dias pós-imunização apresentam expressão reduzida dos genes pró-inflamatórios Ifng, Tbx21, II-17, RorC e aumento na expressão de genes Bdnf e ldo. Coletivamente, nossos dados demonstram que as htMSCs exercem um papel imunomodulador no modelo da EAE. O efeito imunomodulador das htMSCs é promissor, podendo ser utilizado no futuro como estratégia de tratamento para doenças autoimunes ou neurodegenerativas.

Palavras chave: 1. Células tronco. 2. Autoimunidade. 3. Imunomodulação. 4. Encefalomielite Experimental Autoimune. 


\begin{abstract}
Freitas, C. L. Immunomodulatory Properties of Mesenchymal Stromal Stem Cells in Experimental Autoimmune Encephalomyelitis. [PhD thesis (Immunology)]. São Paulo, Instituto de Ciências Biomédicas, Universidade de São Paulo; 2019.
\end{abstract}

Multiple sclerosis is an autoimmune degenerative disease mediated by $\mathrm{T}$ lymphocytes auto-reactive to myelin epitopes that initially activate in the periphery and infiltrate the central nervous system, leading to inflammation and demyelination. The murine model, Experimental Autoimmune Encephalomyelitis (EAE) has been used to study the possible mechanisms involved in multiple sclerosis. Stromal mesenchymal stem cells are undifferentiated multipotent cells that have immunomodulatory properties. Human uterine tubes called htMSCs are a rich source of stromal mesenchymal stem cells. Thus, since there is no cure for multiple sclerosis, we propose to evaluate the modulatory effect of htMSCs in the EAE model. Our results demonstrate that treatment with htMSCs reduces the expression of CD80, CD86 and MHC II molecules in dendritic cells from spleen and lymph node of treated animals, and increases IL-10 production. At the disease's peak, treated animals showed a reduced clinical score. In the nervous system, there is a decrease in infiltrating cells and activated resident microglia. Treatment with htMSCs reduced the frequency and absolute number of infiltrating Th1 (T CD4 + IFN-Y +) and Th17 (T CD4 + IL-17 +) cells in the brain. Spinal cord analyzed at peak and 30 days post-immunization showed reduced expression of pro-inflammatory Ifng, Tbx21, II-17, RorC genes and increased expression of Bdnf and Ido genes. Collectively, our data demonstrate that htMSCs play an immunomodulatory role in the EAE model. The immunomodulatory effect of htMSCs is promising and may be used in the future as a treatment strategy for autoimmune or neurodegenerative diseases.

Keywords: 1. Stem cells. 2. Autoimmunity. 3. Imunnemodulation. 4. Experimental autoimmune encephalomyelitis. 


\section{LISTA DE ILUSTRAÇÕES E QUADROS}

Figura 1 - Esquema representativo da resposta imunológica na esclerose múltipla.

Figura 2 - Esquema representativo do efeito das MSCs em células do sistema imune. 26

Figura 3 - Estratégia de Gate utilizada para análise de população de linfócitos infiltrantes e ativação da microglia no cérebro de animais com EAE tratados ou não com htMSCs. 36

Figura 4 - Estratégia de Gate utilizada para análise da ativação das populações de macrófagos e células dendríticas no baço e linfonodo de animais com EAE tratados ou não com htMSCs.

Figura 5 - Estratégia de Gate utilizada para análise de expressão de linfócitos e de citocinas intracelulares no baço, linfonodo e cérebro de camundongos com EAE tratados ou não com $h t M S C s$. 39

Figura 6 - Isolamento, cultura e diferenciação de htMSCs. 45

Figura 7 - Caracterização fenotípica das $h t M S C s$ .46

Figura 8 - O tratamento com htMSCs reduz o score clínico da EAE in vivo, reduz a neuroinflamação e danos histopatológicos e modula a expressão gênica na medula espinhal. .50

Figura 9 - O tratamento com duas doses de $h t M S C s$ é mais efetivo em reduzir o score clínico da EAE in vivo.

Figura 10 - Perfil de células dendríticas e macrófagos no baço e linfonodos de animais com EAE 7 dias pós-imunização. 
Figura 11 - Expressão das moléculas CD86, CD80 e MHC II é reduzida em macrófagos $\left(\mathrm{F} 4 / 80^{+} \mathrm{CD} 11 \mathrm{~b}^{+}\right)$nos linfonodos de animais com EAE tratados com htMSCs.

Figura 12 - Expressão das moléculas CD86, CD80 e MHC II é reduzida em células dendríticas $\left(\mathrm{CD} 11 \mathrm{c}^{+} \mathrm{MHC} \mathrm{II}^{+}\right)$nos linfonodos de animais com EAE tratados com $h t M S C s$. .56

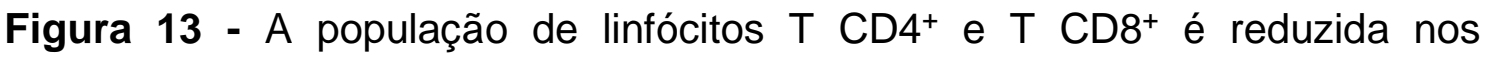
linfonodos de animais tratados com htMSCs nos estágios iniciais da EAE 58

Figura 14 - Perfil de citocinas do baço e linfonodos de animais tratados com htMSCs 7 dias pós-imunização e após re-estimulação in vitro com MOG .59

Figura 15 - $O$ tratamento com htMSCs reduz a progressão da EAE in vivo, mas não modula o perfil de células dendríticas e macrófagos no baço de animais com EAE 16 dias pós-imunização 61

Figura 16 - Expressão das moléculas CD86, CD80 é reduzida em células dendríticas (CD11 $\left.\mathrm{c}^{+} \mathrm{MHC} \mathrm{II}^{+}\right)$durante o pico da doença nos baços de animais com EAE tratados com htMSCs. 62

Figura 17 - A população de linfócitos $\mathrm{T} \mathrm{CD4}^{+}$e $\mathrm{T} C D 8^{+}$não é modulada no baço de animais tratados com $h t M S C s$ no pico da EAE 64

Figura 18 - Perfil de citocinas do baço de animais tratados com htMSCs 16 dias pós-imunização e após re-estimulação in vitro com MOG 65

Figura 19 - O tratamento com htMSCs reduz o infiltrado celular no SNC de animais com EAE

Figura 20 - O tratamento com $h t M S C s$ reduz o infiltrado de células Th1 e Th17 no SNC de animais com EAE 
Figura 21 - Perfil de citocinas de células mononucleares do cérebro de animais tratados com htMSCs 16 dias pós-imunização e após re-estimulação in vitro com MOG.

Figura 22 - O tratamento com $h t M S C$ s reduz a neuroinflamação e modula a expressão gênica na medula espinhal.

Figura 23 - $h$ tMSCs diminuem a expressão de genes de receptores e citocinas quimiotáticas. .74

Quadro 1 - Genes representados na placa Mouse Innate \& Adaptative Immune Responses PCR Array .42 


\section{LISTA DE TABELAS}

Tabela 1 - Dados numéricos de htMSCs positivas para os marcadores citados na figura 7 .

Tabela 2 - Média do score clínico de animais com EAE tratados com apenas uma dose de $h t M S C s$ no dia 0 .48

Tabela 3 - Média do score clínico de animais com EAE tratados com duas doses de $h$ tMSCs nos dias 0 e 10 pós-imunização. 49

Tabela 4 - Média do score clínico de animais com EAE tratados com apenas uma dose de $h t M S C s$ no dia 10 pós imunização .52 


\section{SUMÁRIO}

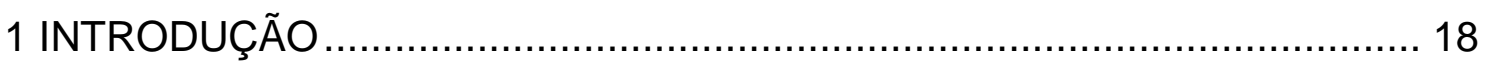

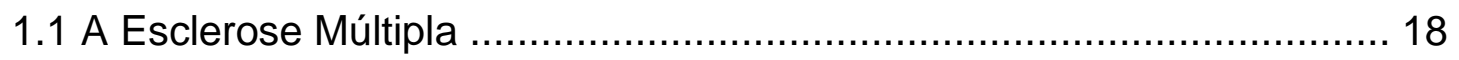

1.2 Células Tronco Mesenquimais Adultas (MSCs) .................................... 23

1.3 Efeitos modulatórios das MSCs na EAE ............................................ 25

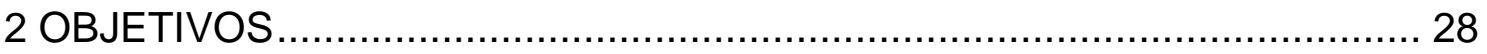

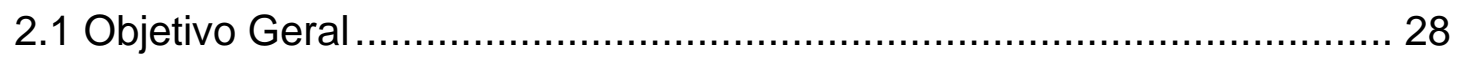

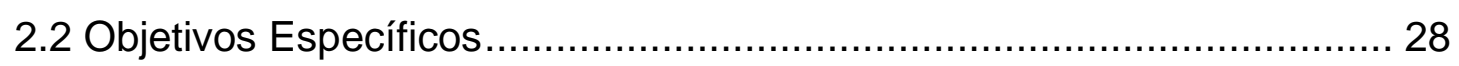

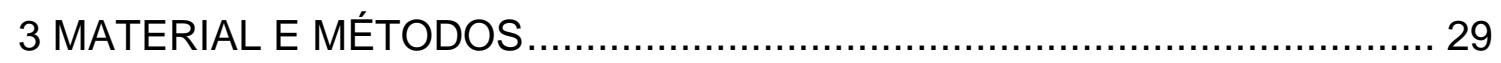

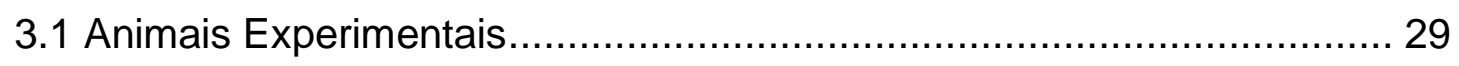

3.2 Obtenção de tubas uterinas, isolamento e cultura de $h t M S C s$............... 29

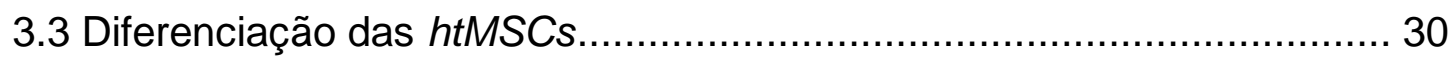

3.3.1 - Diferenciação Adipogênica ..................................................... 30

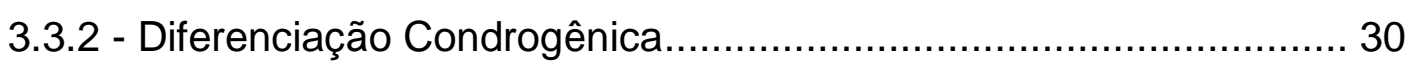

3.3.3 - Diferenciação Osteogênica........................................................ 30

3.4 Indução de EAE nos camundongos C57BL/6 ………........................ 31

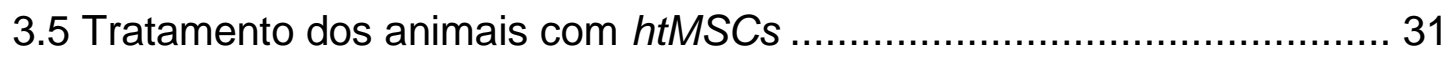

3.6 Extração de RNA e síntese de DNA complementar (cDNA) ................... 31

3.7 Quantificação por PCR em Tempo Real ............................................ 32

3.8 Obtenção de células mononucleares do sistema nervoso central .......... 33

3.9 Obtenção de células do baço e linfonodos ............................................. 34

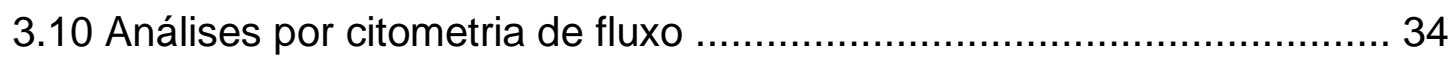

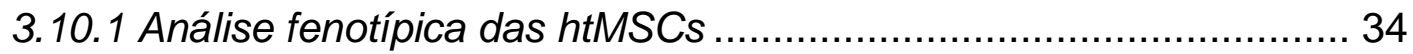

3.10.2 Avaliação de moléculas de ativação em células dendríticas,

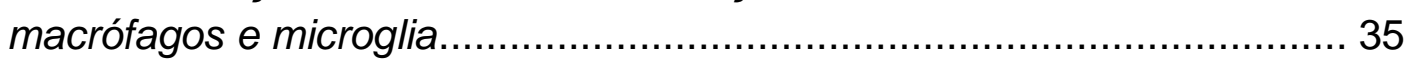

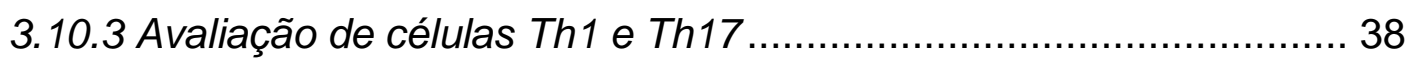

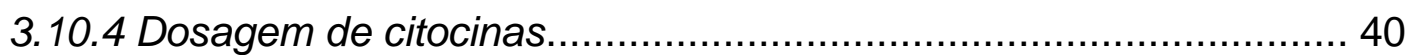

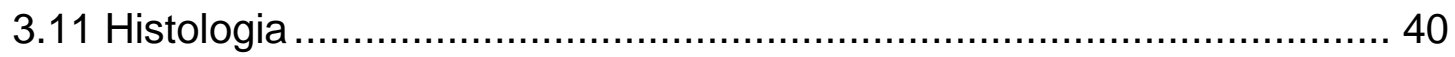

3.11.1 Coloração por Hematoxilina e Eosina ......................................... 40

3.11.2 Coloração por Luxol Fast Blue ........................................................ 41

3.12 Síntese de cDNA para PCR Array ...................................................... 41

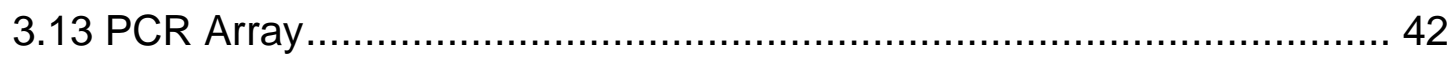

3.14 Análise dos dados obtidos por PCR Array ...................................... 43 
3.15 Análises estatísticas 43

4 RESULTADOS..

4.1 Isolamento, cultura e análise fenotípica das htMSCs

4.20 tratamento com htMSCs reduz o score da EAE in vivo a longo prazo 47

4.2.1 As htMSCs são capazes de reduzir a progressão da EAE.

4.2.2 O tratamento com htMSCs reduz a neuroinflamação e danos histopatológicos no cérebro e medula espinhal de animais com EAE. 48

4.2.3 As htMSCs inibem a transcrição de genes pró-inflamatórios dos linfócitos patogênicos e induzem a transcrição de genes imunomodulatórios

4.2.4 O tratamento com duas doses de htMSCs é mais efetivo em reduzir a progressão da EAE.

4.3 Avaliação da Imunomodulação das $h t M S C s$ durante o estabelecimento da EAE na periferia.

4.3.1 Perfil de macrófagos e células dendríticas no baço e linfonodo durante o estabelecimento da EAE na periferia.

4.3.2 htMSCs modulam a apresentação de antígenos e ativação de macrófagos e células dendríticas no linfonodo de animais no início da EAE

4.3.3 htMSCs reduzem a população de linfócitos $T C D 4^{+}$no linfonodo de animais no início da EAE.

4.4 Avaliação da Imunomodulação das htMSCs durante o pico da EAE na periferia.

4.4.1 Perfil de macrófagos e células dendríticas no baço durante o pico da

EAE na periferia 60

4.4.2 htMSCs não conseguem modular a população de linfócitos $T C D 4^{+}$no baço de animais durante o pico da EAE na periferia.

4.5 Imunomodulação das htMSCs no sistema nervoso central durante o pico da $E A E$

4.5.1 O tratamento com duas doses de htMSCs reduz a neuroinflamação impedindo células inflamatórias de se infiltrarem no cérebro e diminuindo a ativação das células da microglia 66

4.5.2 O tratamento com htMSCs reduz a infiltração de linfócitos patogênicos Th1 e Th17 no SNC.

4.5.3 O tratamento com htMSCs reduz a produção das citocinas IFN-y e IL17 no cérebro 68

4.6 Avaliação da medula espinhal no pico da doença em animais com EAE tratados com htMSCs 
4.6.1 As htMSCs inibem a transcrição dos genes pró-inflamatórios e induzem a transcrição de genes imunomodulatórios na medula espinhal durante o pico da doença

4.6.2 As htMSCs diminuem a expressão de receptores de quimiocinas e citocinas quimiotáticas na medula espinhal de camundongos EAE .......... 71

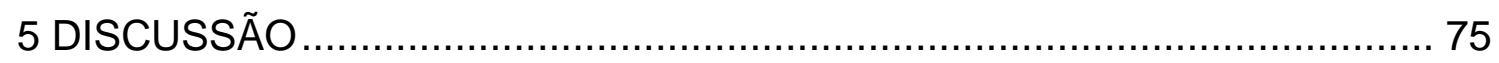

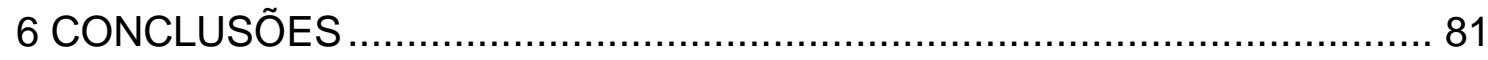

As htMSCs suprimem o estabelecimento dos sintomas e a progressão da doença em animais com EAE;

htMSCs modulam a transcrição gênica na medula espinhal inibindo a transcrição de genes relacionados aos perfis Th1 e Th17 e aumentando a expressão de genes imunomoduladores;

7 REFERÊNCIAS 82

Anexos. 90 


\section{INTRODUÇÃO}

\subsection{A Esclerose Múltipla}

A Esclerose Múltipla (EM) é a doença idiopática inflamatória desmielinizante do sistema nervoso central (SNC) mais prevalente. Dados emitidos pela Federação Internacional de Esclerose Múltipla (MSIF, Multiple Sclerosis International Federation) e pela Organização Mundial da Saúde (WHO, World Health Organizazion) relatam que, em 2008 estimava-se que cerca de 2,1 milhões de pessoas eram afetadas pela EM no mundo, sendo predominantemente jovens adultos na América do Norte e Europa, com prevalência de 140 e 108 casos a cada 100.000 habitantes, respectivamente (Hauser and Oksenberg 2006). Em 2013, esse número aumentou para 2,3 milhões de pessoas, na proporção de 2:1 mulheres para cada homem (MSFI, 2013).

No Brasil, calcula-se que a prevalência da doença seja de 15 a 18 casos para cada 100 mil habitantes, chegando a 27 na região sul do Brasil (Finkelsztejn, Lopes et al. 2014). Estudos feitos em diferentes regiões do país relatam que dentre a população brasileira, a maior prevalência reside na forma recorrente/remitente e em mulheres (MSIF, 2013). Além disso, observou-se uma menor relação entre indivíduos da raça negra, quando comparados aos indivíduos de raça branca e parda (Grzesiuk 2006).

Essa doença é caracterizada pelo dano axonal mediado pelo sistema imune, produzindo lesões desmielinizantes no cérebro e medula espinhal que rompem a sinalização neuronal de forma significativa (Charcot 1881). Clinicamente, os sintomas neurológicos em pacientes com EM variam de leve a grave e tipicamente incluem um ou mais dos seguintes sintomas: sintomas sensoriais $(40 \%)$, sintomas motores $(39 \%)$, e outros sintomas como sensibilidade ao calor, fadiga (30\%), alterações emocionais, alterações cognitivas (10\%) (Bronner, Elran et al. 2010). 
O curso da doença é altamente variável e imprevisível, sendo dividida em i) primária progressiva, ii) secundária progressiva, ou iii) remitente recorrente (Barkhof, Scheltens et al. 1992, Miller, Vanderlugt et al. 1997, Filippi, Rocca et al. 1998). No momento do diagnóstico, $85 \%$ das pessoas apresentam EM remitente recorrente. Estima-se que de 10 dessas pessoas, 8 irão desenvolver EM secundária progressiva. Cerca de 10\% das pessoas são diagnosticadas com EM primária progressiva e 5\% com EM progressiva recorrente (MSFI, 2013).

A EM é predominantemente mediada por linfócitos $T$ auto-reativos à epítopos de mielina que são inicialmente ativados nos tecidos linfáticos periféricos e, subseqüentemente, infiltram o SNC (Pettinelli and McFarlin 1981). Macrófagos (MO), células dendríticas (DC), linfócitos $T$ e $B$, e células da microglia já foram descritas como presentes nos locais de lesão (Ireland and Monson 2011, Chen, Chen et al. 2012, Olah, Amor et al. 2012). Após ativação e expansão clonal, tais células infiltram o SNC e, após serem ativadas in situ por células dendríticas residentes (Bailey, Schreiner et al. 2007) e células da micróglia (Ponomarev, Shriver et al. 2005), estas passam a secretar uma série de citocinas pró-inflamatórias que induzem ativação de astrócitos, células da microglia e células endoteliais, promovendo o processo inflamatório local e o estabelecimento das lesões (Figura 1).

Por outro lado, são os macrófagos e os linfócitos T CD8 citotóxicos (Goverman, Perchellet et al. 2005) que medeiam as lesões propriamente ditas, induzindo a morte de oligodendrócitos pela liberação de espécies reativas do oxigênio e de citocinas como o TNF- $\alpha$, além de granzima e perforina. Já os linfócitos $B$ são as células que mais chamam atenção durante a EM, pois atuam diretamente em várias etapas da resposta imune ao sistema nervoso. Dentre suas ações podemos citar a apresentação de antígenos, liberação de citocinas pró-infamatórias (TNF-a, IL-6, IL-12) e ativação da via clássica do sistema complemento através de auto-anticorpos. Tais ações influenciam diretamente a resposta de macrófagos e linfócitos aumentando a resposta próinflamatória e promovendo um aumento nas lesões do SNC (Krumbholz, Derfuss et al. 2012). 
Figura 1: Esquema representativo da resposta imunológica na esclerose múltipla.

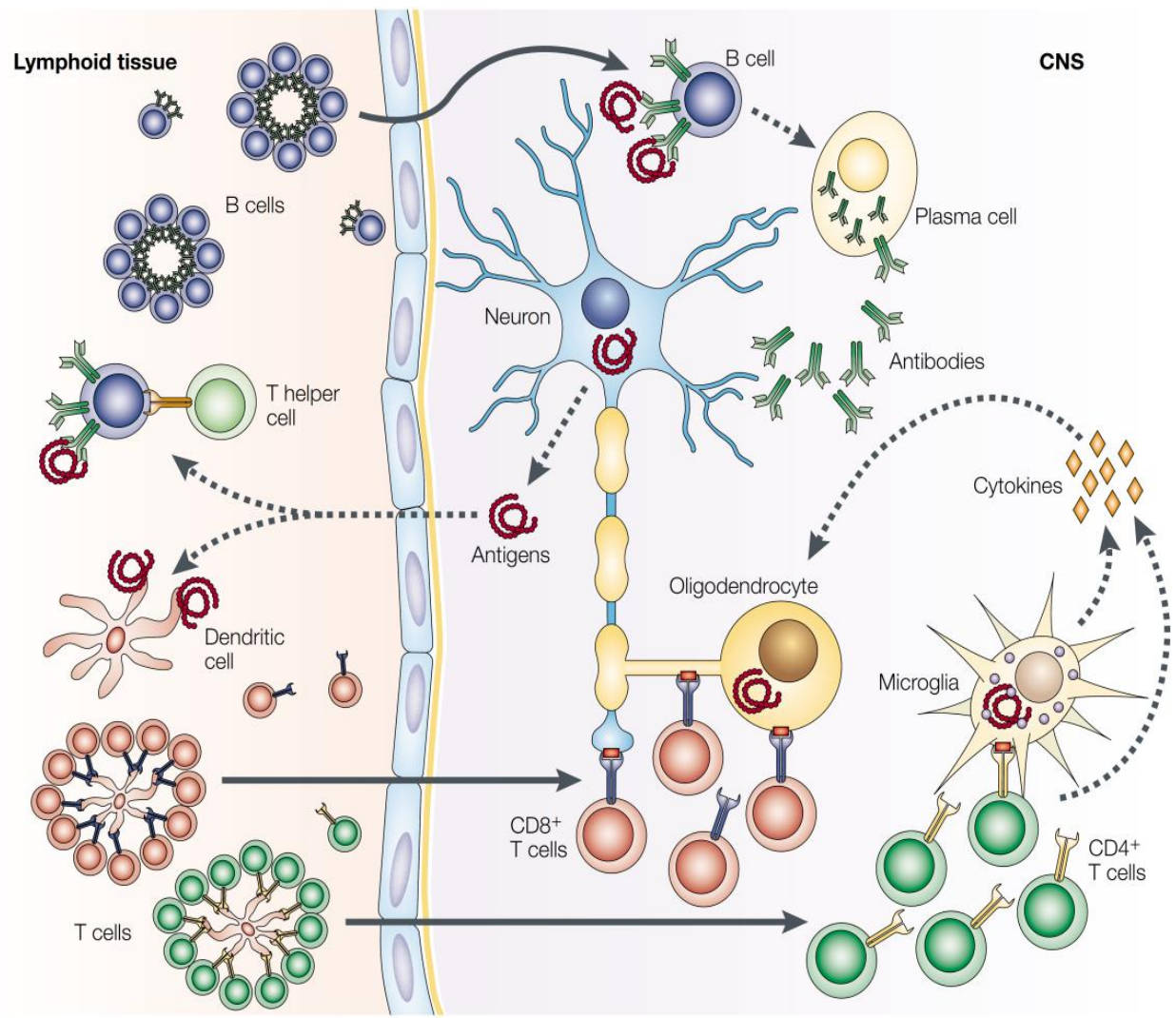

Fonte: Hemmer B. et al., 2002 - Nature Reviews Neuroscience.

A EAE (do inglês, Experimental Autoimmune Encephalomyelitis) é um modelo desenvolvido em roedores há 50 anos (Kabat, Wolf et al. 1947) que compartilha diversas similaridades com os episódios inflamatórios agudos da EM, tanto clinicamente, quanto histopatologicamente. A EAE tem sido um modelo fundamental para elucidar os potenciais mecanismos que levam aos eventos que ocorrem na EM e seu uso tem promovido o desenvolvimento de estratégias de tratamentos.

A indução da EAE se dá através da inoculação subcutânea de antígenos de mielina como $\mathrm{MOG}_{33-35}$ (do inglês, Myelin Oligodendrocyte Glycoprotein), MBP (do inglês, Myelin Basic Protein), e também PLP (do inglês, Proteolipoprotein) emulsificados em CFA (do inglês, Complete Freund Adjuvant). Tal procedimento leva a uma intensa ativação da resposta imune através da produção de citocinas pró-inflamatórias e quimiocinas, expansão de clones de linfócitos T CD4 e CD8 encefalitogênicos e o consequente 
rompimento da barreira hematoencefálica e ativação das células residentes, tais como células da microglia e astrócitos (Friese, Montalban et al. 2006).

Na periferia, linfócitos T CD4+ diferenciam-se em Th1 e Th17, os quais têm sido envolvidos na patogênese da EAE (Dardalhon, Korn et al. 2008). De fato, as citocinas IFN- $\gamma$ e IL-17 são conhecidas por serem importantes na neuroinflamação, uma vez que experimentos mostraram que camundongos IL17 knockouts são altamente resistentes à indução de EAE (Komiyama, Nakae et al. 2006) enquanto camundongos deficientes em IFN-y são mais suscetíveis, sugerindo que células Th17 podem ser mais relevantes do que as células Th1 nessa doença.

Em contrapartida, O'Connor et al., utilizando o método da EAE passiva, mostrou que preparações com células IFN- $\gamma^{+}$juntamente com células IL-17+ eram patogênicas; preparações apenas com células IFN- $\gamma^{+}$, eram também patogênicas; apenas com células $\mathrm{LL}_{-1} 17^{+}$, não eram capazes de induzir a doença nos animais. Com isso, o grupo concluiu que apenas as células Th1 são capazes de infiltrar o SNC não inflamado e, após a lesão ser estabelecida primeiramente pelas células Th1, as células Th17 aparecem no SNC (O'Connor, Prendergast et al. 2008).

As células Th17 são reguladas pela expressão de fator de transcrição RORyT (Ivanov, McKenzie et al. 2006) e pela secreção de IL-17A, IL-17F e IL23 (Kreymborg, Etzensperger et al. 2007) de uma maneira dependente de IL-6 + TGF $\beta$ (Zhou, Ivanov et al. 2007). Estudos com humanos reportaram que pacientes com EM, durante a doença ativa, possuiam níveis de mRNA de IL-6 e IL-17 elevados no sangue e fluido espinhal, e que células parenquimais do cérebro, como células da microglia, células endoteliais e astrócitos, expressam constitutivamente o receptor IL-17R (Das Sarma, Ciric et al. 2009).

Em um trabalho realizado com camundongos deficientes em Act1 e mastócitos, molécula adaptadora da sinalização de IL-17, demonstrou-se que a sinalização nessas células leva à secreção de outras moléculas inflamatórias como CXCL2, CXCL9, CXCL12, IL-6 e MMP-9 (Kang, Altuntas et al. 2010). 
Todas essas moléculas contribuem para o recrutamento de mais células inflamatórias e, assim, o perpetuamento das lesões.

Ainda, através do sistema Th17 reporter utilizando-se do camundongo 1117 Cre YFP $^{+}$, foi descrito que o destino de células Th17 difere em um ambiente de inflamação aguda de um ambiente de inflamação crônica in vivo. Durante o desenvolvimento da EAE, na medula espinhal, dirigido pela citocina IL-23, ocorre o swich das células Th17 para células chamadas "ex-Th17", as quais produzem IFN-y e outras citocinas pró-inflamatórias (Hirota, Duarte et al. 2011). Desse modo parece lógico que qualquer abordagem que consiga suprimir a geração e expansão de células Th17 poderia resultar na redução da severidade da doença.

Em relação à discussão acerca de qual população de linfócitos tem o papel crucial durante o processo inflamatório no SNC no modelo da EAE, foi descrito que essas populações infiltram o SNC por vias distintas. Enquanto os linfócitos Th1 infiltram o SNC por um mecanismo mediado pela integrina $\alpha 4$, particularmente VLA-4 ( $\alpha 4 \beta 1$ ); os linfócitos Th17 utilizam $\beta 2$ integrinas LFA-1 ( $\alpha \mathrm{L} \beta 2$ ), atingindo o tecido alvo de maneira a4 independente (Rothhammer, Heink et al. 2011).

Por fim, Prajeeth et al. comparou a resposta de micróglia e astrócitos entre animais selvagens e deficientes em integrina a4 nos linfócitos T CD4, nos quais o tráfego de células Th1 para o cérebro é afetado durante a EAE. Os camundongos deficientes em a4 apresentaram pouca ativação da microglia, porém, a ativação de astrócitos foi semelhante à de camundongos do tipo selvagem nas regiões do cérebro povoadas com infiltrados Th17, sugerindo que as células Th17 têm como alvo astrócitos e não microglia (Prajeeth, Dittrich-Breiholz et al. 2018). Esse e outros dados descritos acima sugerem que ambas as populações de linfócitos têm papel na patogenicidade da EAE, porém, podem atuar em momentos ou locais diferentes.

O tratamento atual é focado em terapias anti-inflamatórias e imunomodulatórias, as quais têm sido um tanto bem sucedidas no tratamento 
de episódios agudos de EM. Dentre as drogas mais utilizadas podemos citar o IFN- $\beta$ : Betainterferona 1a $\left(\right.$ Avonex $\left.^{\circledR}\right)$, Betainterferona 1b (Betaferon $\left.{ }^{\circledR}\right)$; e também Acetato de Glatirâmer (Copaxone $\left.{ }^{\circledR}\right)$; além de Cloridrato de fingolimode (Gilenya $\left.^{\mathrm{TM}}\right)$, Alentuzumabe (Lemtrada ${ }^{\circledR}$ ), Fumarato de dimetila (Tecfidera ${ }^{\mathrm{TM}}$ ) e Teriflunomida (Aubagio $^{\circledR}$ ) (Jacobs, Cookfair et al. 1996, Jacobs, Beck et al. 2000, Gold, Kappos et al. 2012, Sanchez-de la Rosa, Sabater et al. 2012, Freedman 2013, Ruck, Afzali et al. 2016, Link, Ramanujam et al. 2017, Pilote, Simard et al. 2017). Anticorpos monoclonais como o Natalizumab (Tysabri $\left.{ }^{\circledR}\right)$, anti-integrina a4; Rituximab (Rituxan ${ }^{\circledR}$ ) e Ocrelizumab (Ocrevus ${ }^{\circledR}$ ), anti-CD20, também são eventualmente utilizados (Moreno Torres and Garcia-Merino 2017), porém, foram relatados recentemente casos graves de efeitos adversos (Havla, Gerdes et al. 2011).

Infelizmente, não foi desenvolvido nenhum tratamento que iniba a progressão da doença em longo prazo ou sua cura por completo, uma vez que é necessária uma melhor compreensão da etiologia e da fisiopatogênese dessa doença. Nesse contexto, a busca por terapias alternativas, com menos reações adversas, é algo mandatório no caso de doenças crônicas.

\subsection{Células Tronco Mesenquimais Adultas (MSCs)}

Células tronco estromais adultas (do inglês, Mesenchymal Stromal Cells) são tipicamente definidas como células multipotentes não diferenciadas que possuem a capacidade de auto-renovação e o potencial de se diferenciar em linhagens celulares distintas (Dominici, Le Blanc et al. 2006). Tal população constitui um reservatório nos tecidos conjuntivos na maioria dos órgãos e estão envolvidas na manutenção e reparo durante a vida pós-natal de um indivíduo.

Apesar de serem funcionalmente heterogêneas, as populações de MSCs humanas ( $h M S C S$ ) isoladas de diferentes tecidos como medula óssea, músculo esquelético, tecido adiposo, polpa dentária, placenta e cordão umbilical apresentam um perfil similar de expressão de receptores de superfície (Bobis, Jarocha et al. 2006, Phinney and Prockop 2007, de Mendonca Costa, Bueno et al. 2008, Evangelista, Soncini et al. 2008, Secco, Zucconi et al. 2008, 
Valtieri and Sorrentino 2008, Warburton, Perin et al. 2008). Entretanto, sabe-se que células-tronco adultas são definidas mais por suas propriedades funcionais do que por marcadores fenotípicos (Zhang, Liu et al. 2009).

As tubas uterinas humanas (do inglês, Human Fallopian Tubes) têm a mesma origem embrionária do útero. Estas sofrem mudanças dinâmicas induzidas pelo sistema endócrino durante o ciclo menstrual, como o crescimento celular e regeneração a fim de prover o ambiente requerido para a manutenção da viabilidade dos gametas femininos e masculinos, fertilização, o desenvolvimento inicial do embrião e seu deslocamento para o útero (Lyons, Saridogan et al. 2006).

Tubas uterinas descartadas durante procedimentos de esterilização feminina ou histerectomia são fontes ricas de células mesenquimais (htMSCs Human Tubal Mesenchymal Stromal Cells) (Jazedje, Perin et al. 2009), as quais são responsáveis, em parte, pelo processo de regeneração deste tecido. De fato, a capacidade regenerativa extraordinária do endométrio humano após a menstruação, no período pós-parto, após procedimentos cirúrgicos (curetagem uterina e ablação endometrial) e mulheres na menopausa submetidas à terapia de reposição hormonal, sugere que nichos de htMSCs encontrados nesses tecidos seriam responsáveis por esses processos regenerativos (Gargett 2007). Sendo assim, essas células apresentam um potencial interessante nos estudos tanto de medicina regenerativa como por seu potencial imunomodulador.

Nosso grupo demonstrou que o tratamento de camundongos com EAE com células-tronco mesenquimais derivadas de endométrio humano (hedMSCs - Human Endometrial-derived Mesenchymal Stem Cells) diminuiu a inflamação do SNC e a progressão da doença devido à diminuição do infiltrado de células T encefalitogênicas no SNC (Peron, Jazedje et al. 2012). Os mecanismos sugeridos são derivados da análise de parâmetros anti-inflamatórios importantes, como aumento na expressão de Foxp3, IL-10, IL-27 e também de indoleamina-2,3-dioxigenase (IDO), uma enzima sabidamente supressora da proliferação de linfócitos T. Nesse contexto, assim como as hedMSCs, as 
htMSCs são também grandes candidatas para o estudo de estratégias terapêutica no tratamento da EM e outras doenças autoimunes.

\subsection{Efeitos modulatórios das MSCs na EAE}

Estudos demonstraram que MSCs podem suprimir a ativação e função de várias células do sistema imune inato e adaptativo, incluindo macrófagos, neutrófilos, células NK, células dendríticas, linfócitos T e B (Uccelli, Moretta et al. 2008, Le Blanc and Mougiakakos 2012, Shi, Su et al. 2012, de Girolamo, Lucarelli et al. 2013). Nas DCs, por exemplo, as MSCs têm capacidade de inibir a diferenciação de monócitos CD14+ para DCs maduras (Jiang, Zhang et al. 2005), inibir a expressão de MHC II, CD80, CD86, e produção de IL-1ß, IL-12 e TNF (Zhang, Ge et al. 2004, Beyth, Borovsky et al. 2005).

As MSCs exibem propriedades imunomodulatórias e capacidade de migração direcional através do contato direto célula-célula e através da liberação de fatores imunossupressores solúveis (Uccelli, Moretta et al. 2008). Os principais fatores moduladores relacionados são: TGF- $\beta$, IFN- $\gamma$, NO, IDO, TSG6, PGE2, HO-1, antagonistas do receptor IL-1, IL-10 e uma variante da quimiocina CCL2 (Locatelli, Maccario et al. 2007, Ortiz, Dutreil et al. 2007, DelaRosa, Lombardo et al. 2009, Lee, Pulin et al. 2009, Nemeth, Leelahavanichkul et al. 2009, Rafei, Campeau et al. 2009, Spaggiari, Abdelrazik et al. 2009, Nemeth, Keane-Myers et al. 2010, Shi, Su et al. 2012).Tamanha quantidade de fatores supressores são aparentemente responsáveis não só por sua capacidade imunomoduladora (Figura 2), mas também pelo fato de serem tolerantes alogenicamente.

De certo, as propriedades imunomodulatórias das MSCs são benéficas, no entanto, a capacidade imunossupressora não é um fenômeno constitutivo, e sim, ocorre em advento de um milieu inflamatório, ou seja, as citocinas presentes no ambiente inflamatório ativam a função imunossupressora das MSCs (Ren, Zhang et al. 2008). Dessa forma, MSCs não suprimem reações imunológicas a 
Figura 2 -Esquema representativo do efeito das MSCs em células do sistema imune

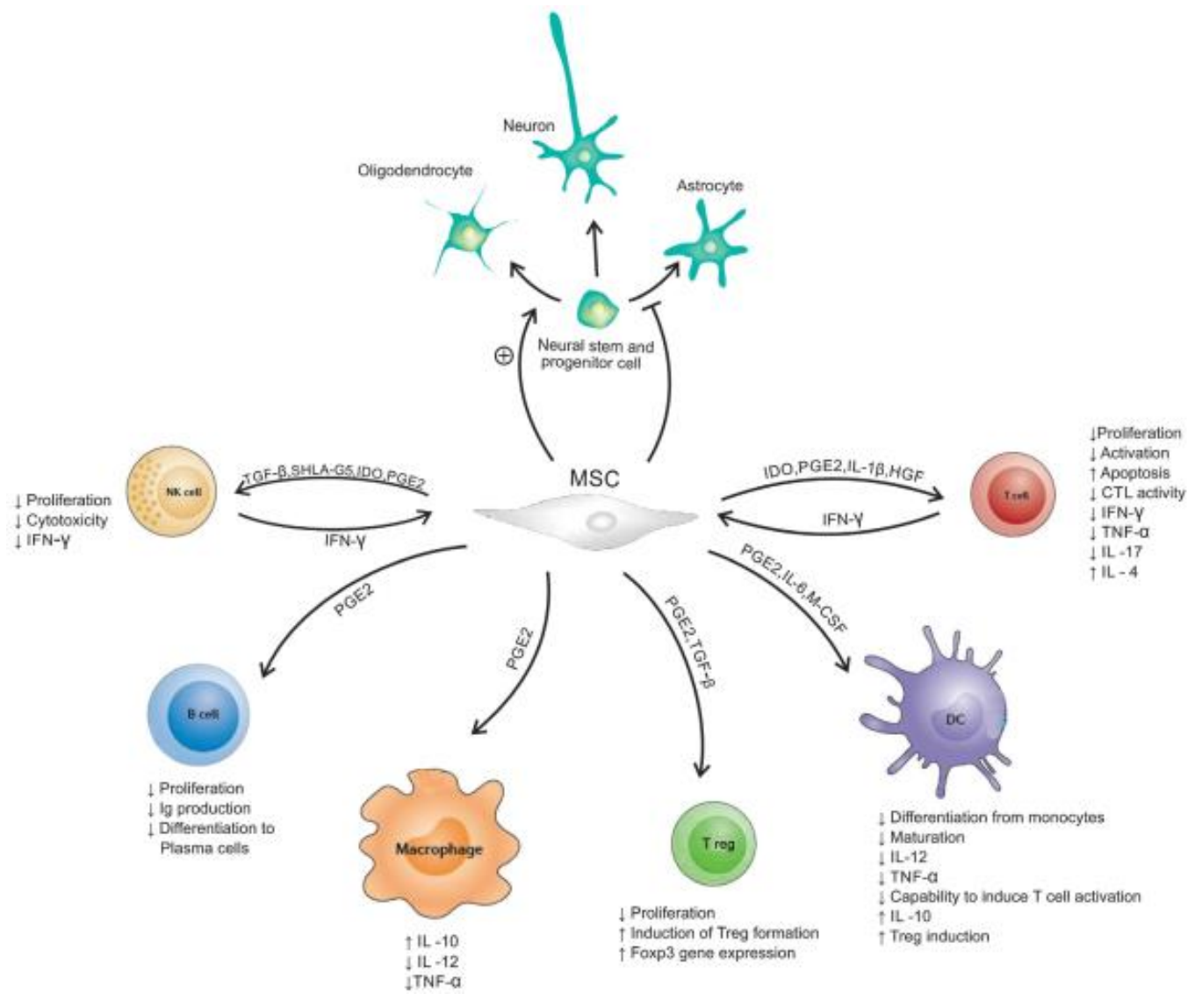

Fonte: Gharibi T. et al., 2015 - Cellular Immunology.

não ser que tenham sido previamente estimuladas por uma combinação de

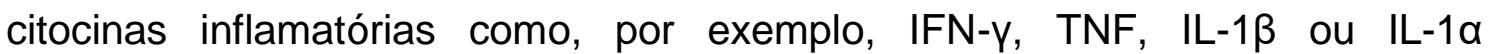
(Krampera, Cosmi et al. 2006, Ortiz, Dutreil et al. 2007, DelaRosa, Lombardo et al. 2009, Lee, Pulin et al. 2009, Nemeth, Leelahavanichkul et al. 2009, Rafei, Campeau et al. 2009, Spaggiari, Abdelrazik et al. 2009, Nemeth, Keane-Myers et al. 2010, Shi, Su et al. 2012). Por fim, X. Han et al demonstrou que as citocinas IFN-y e TNF- $\alpha$ agem sinergicamente no estímulo de MSCs e, o efeito imunossupressor é significativamente aumentado através da indução da expressão de iNOS nas MSCs, tanto in vitro quanto in vivo, quando a citocina inflamatória IL-17 é adicionada (Han, Yang et al. 2014).

No modelo de EAE, hMSCs de diferentes fontes já foram utilizadas: derivadas de tecido adiposo, medula óssea, polpa de dentes, geléia de Wharton, cordão umbilical, placenta (Wang, Kimbrel et al. 2014, Liao, Pham et 
al. 2016, Selim, Selim et al. 2016, Shalaby, Sabbah et al. 2016, Shimojima, Takeuchi et al. 2016, Anderson, Gonzalez-Rey et al. 2017, Giacoppo, Thangavelu et al. 2017, Torkaman, Ghollasi et al. 2017, Donders, Bogie et al. 2018). De um modo geral, as $h M S C s$ foram capazes de reduzir a expansão de células Th17 pró-inflamatórias antígeno-específicas (Shalaby, Sabbah et al. 2016), induzir supressão da produção de IFN-y e IL-17 (Donders, Vanheusden et al. 2015, Torkaman, Ghollasi et al. 2017), aumentar os níveis da citocina anti-inflamatória IL-10 (Hou, Ryu et al. 2013, Payne, Sun et al. 2013), diminuir o infiltrado inflamatório e atenuar a desmielinização (Liu, Zhang et al. 2013, Liao, Pham et al. 2016, Shimojima, Takeuchi et al. 2016)

Essas propriedades imunomodulatórias surpreendentes sugerem que MSCs tem um grande potencial para tratar distúrbios inflamatórios. Além do modelo da EAE, vale mencionar outros modelos nos quais as hMSCs humanas são utilizadas para o estudo de sua capacidade de modular células do sistema imune, como Lupus Eritematoso Sistêmico (Park, Kwok et al. 2015), Doença do enxerto contra o hospedeiro (GvHD) (Kim, Moon et al. 2015, Luz-Crawford, Torres et al. 2016), Colite ulcerativa (Fuenzalida, Kurte et al. 2016) e Uveíte (Lee, Ko et al. 2015). Todos esses trabalhos mostram a redução das populações de linfócitos Th1 e Th17 frente ao tratamento com hMSCs.

Para a realização plena desse potencial, os mecanismos exatos pelos quais as hMSCs medeiam a imunomodulação durante vários processos ainda precisam ser determinados e estão sob investigação. Para tanto, no presente projeto, visamos avaliar in vivo o potencial imunomodulador das htMSCs no modelo de EAE. 


\section{OBJETIVOS}

\subsection{Objetivo Geral}

Avaliar a capacidade imunomoduladora de células tronco estromais mesenquimais derivadas de tubas uterinas humanas ( $h t M S C s$ ) utilizadas como tratamento no modelo da encefalomielite experimental autoimune (EAE).

\subsection{Objetivos Específicos}

- Avaliar a progressão da EAE em animais tratados ou não com htMSCs com diferentes estratégias terapêuticas;

- Avaliar o fenótipo de macrófagos e células dendríticas no baço e linfonodos de animais com EAE tratados ou não com htMSCs;

- Avaliar as populações de linfócitos Th1 e Th17 no baço, linfonodos e sistema nervoso central de animais com EAE tratados ou não com htMSCs;

- Avaliar o padrão de citocinas secretadas por células do baço, linfonodos e sistema nervoso central de animais com EAE e tratados ou não com htMSCs;

- Avaliar células infiltrantes no SNC quanto às populações de linfócitos, macrófagos e ativação da micróglia;

- Avaliar o infiltrado inflamatório e desmielinização na medula espinhal de animais com EAE tratados ou não com htMSCs;

- Avaliar a expressão dos genes Bdnf, Ifng, Tbx21, ILL-17A, Rorc, Bdnf, II27 e Ido na medula espinhal de animais com EAE tratados ou não com htMSCs; 


\section{MATERIAL E MÉTODOS}

\subsection{Animais Experimentais}

Foram utilizados camundongos fêmeas da linhagem C57BL/6 selvagens (WT) de 2-3 meses de idade mantidos no Biotério do Departamento de Imunologia do Instituto de Ciências Biomédicas da Universidade de São Paulo (ICB-USP). Os animais foram mantidos em estantes ventiladas sob condições controladas de temperatura, umidade e iluminação (ciclo claro/escuro de 12 horas). Todos os protocolos foram submetidos à aprovação pelo Comitê de Ética em Pesquisa Animal desta mesma instituição.

3.2 Obtenção de tubas uterinas, isolamento e cultura de $h t M S C s$

As células $h t M S C s$ foram gentilmente cedidas por nossos colaboradores do Centro de Estudo do Genoma Humano (CEGH) do Instituto de Biociências da Universidade de São Paulo e isoladas a partir de amostras de tuba uterinas obtidas em parceria com as clínicas Célula Mater e Centro Especializado em Reprodução Humana (CEERH). As amostras de tuba uterina humanas ( $h F T s$ ) foram obtidas e cultivadas conforme descrito por Jazedje et al., $2009(n=3)$. Cada amostra foi coletada em meio HEPES-buffered Dulbeco Modified Eagle Medium/Hams F-12 (DMEM/F-12; Invitrogen) ou DMEM high glucose (DMEM/High; Invitrogen) suplementado com $10 \%$ de soro fetal bovino (SFB; HyClone, Logan), mantido a $4{ }^{\circ} \mathrm{C}$, e processado em um período de $24 \mathrm{~h}$. Todas hFTs foram lavadas duas vezes em tampão salino fosfato (PBS, Gibco, Invitrogen), cortadas com bisturi, colocadas em tubo falcon de 15 ou $50 \mathrm{~mL}$ e incubadas com $5 \mathrm{~mL}$ de TripLE Express (Invitrogen) por 30 minutos, a $37^{\circ} \mathrm{C}$, em banho-maria. Após o período de incubação, o sobrenadante foi coletado com uma pipeta Pasteur, lavado com $7 \mathrm{~mL}$ de DMEM/F-12 suplementado com $10 \%$ de SFB em um tubo falcon de $15 \mathrm{~mL}$ e centrifugado a $400 \mathrm{~g}$ por cinco minutos a temperatura ambiente. As células foram ressuspendidas em $5 \mathrm{~mL}$ de DMEM/F-12 suplementado com $10 \%$ de SFB, penicilina (100 IU $/ \mathrm{mL}$, Invitrogen) e estreptomicina (100 IU/mL, Invitrogen) e mantidas em garrafas de cultura (25 $\mathrm{cm}^{2}$ ) em um ambiente de $5 \%$ de $\mathrm{CO} 2$ e a $37^{\circ} \mathrm{C}$. O meio de cultura usado para 
a expansão foi trocado a cada $72 \mathrm{~h}$ e duas vezes por semanas subseqüentemente.

\subsection{Diferenciação das $h t M S C s$}

Para avaliar as propriedades de diferenciação das $h t M S C s$, as células aderidas foram submetidas a diferenciação adipogênica, condrogênica e osteogênica usando o kit Invitrogen Stem Pro Differentiation (A1007101, A1007001 e A1007201) conforme protocolo descrito pelo fabricante.

\subsection{1 - Diferenciação Adipogênica}

Células foram mantidas em cultura com o meio de diferenciação por duas semanas. Após a utilização do kit para diferenciação em adipócitos, as células foram obtidas ao dia 14 e avaliadas quanto à acumulação intracelular de vacúolos ricos em lipídios corados com oil red O (Sigma-Aldrich, St. Louis, MO). Para a coloração com oil red $O$, as células foram fixadas com paraformaldeído $4 \%$, por 30 minutos, lavadas e coradas com a solução de oil red $0,16 \%$ por 20 minutos.

\subsection{2 - Diferenciação Condrogênica}

Após duas semanas de cultivo em meio de diferenciação, as células em monocamada foram fixadas com paraformaldeído $4 \%$ por 10 minutos e coradas com Toluidine Blue para deteç̧ão de mucopolissacarídeos da matriz extracelular. O corante foi preparado pela adição de $1 \%$ de Toluidine Blue dissolvido em água destilada, contendo $1 \%$ de borato de sódio, e em seguida filtrado. O corante foi adicionado em cada poço da cultura por 2 minutos, lavados com água destilada e deixados para secagem natural.

\subsection{3 - Diferenciação Osteogênica}

A diferenciação osteogênica foi mostrada pela formação de áreas positivas para hidroxiapatita de cálcio no dia 21. Depois de duas lavagens com 
PBS e uma lavagem com água destilada, as células foram incubadas com 1\% nitrato de prata (Sigma-Aldrich, St. Louis, MO) sobre a luz ultravioleta (UV) por 45 minutos. As células foram incubadas com 3\% tiossulfato de sódio (SigmaAldrich, St. Louis, MO) por 5 minutos. A coloração foi finalizada com o corante Van Gieson. A acumulação de cálcio é indicada pela cor preta.

\subsection{Indução de EAE nos camundongos C57BL/6}

Os animais C57BL/6 WT foram imunizados por via subcutânea com 150 $\mu \mathrm{g}$ de $\mathrm{MOG}_{35-55}$ emulsificados em CFA (Complete Freund Adjuvant) (v/v) em $100 \mu \mathrm{g}$ de $M$. tuberculosis H37. Adicionalmente foram dadas nos períodos $0 \mathrm{e}$ 48 horas após imunização, $0,2 \mu \mathrm{g}$ de toxina de Bordetella pertussis por via intraperitoneal. Os animais foram acompanhados diariamente e o grau de doença foi atribuído da seguinte forma: 0 - sem doença, 1 - perda do tônus da cauda, 2 - patas traseiras parcialmente paralisadas, 3 - paralisia total das patas traseiras, 4 - paralisia total das patas traseiras com paralisia parcial das patas dianteiras, 5 - paralisia completa ou morte.

\subsection{Tratamento dos animais com htMSCs}

As $h t M S C s$ foram removidas das garrafas de culturas por tripsinização, lavadas e contadas na câmara de Neubauer. Em seguida, foram injetadas conforme as estratégias de tratamento utilizadas: 1) uma dose de $1 \times 10^{6}$ células via intra-peritoneal no dia da imunização (dia 0), 2) duas doses de $1 \mathrm{x}$ $10^{6}$ células via intra-peritoneal aos dias 0 e 10 pós-imunização e 3) uma dose de $1 \times 10^{6}$ células via intra-peritoneal no dia 10 pós imunização. Os animais foram então acompanhados diariamente para avaliação do score clínico conforme descrito em 3.4 .

3.6 Extração de RNA e síntese de DNA complementar (cDNA)

A medula espinhal de animais com EAE tratados ou não com as $h t M S C s$ foi dissociada (GentleMACS Dissociator, MyltenyiBiotec) e o mRNA da medula espinhal foi extraído pela adição de $1 \mathrm{~mL}$ do reagente Trizol (Invitrogen, EUA) 
durante 5 minutos a temperatura ambiente. A essa solução foram adicionados $500 \mu \mathrm{L}$ de clorofórmio, o qual promoveu a separação de RNA, DNA e proteínas, após centrifugação a 12000 rcf por 15 minutos. A porção superior (transparente, que contém RNA) foi cuidadosamente retirada e transferida para outro tubo onde foi adicionado $500 \mu \mathrm{L}$ de isopropanol. A mistura foi mantida a temperatura ambiente por 10 minutos. Em seguida, centrifugada a $12000 \mathrm{rcf}$ por 10 minutos e sobrenadante foi retirado cuidadosamente. Ao pellet obtido (nem sempre visível), foi adicionado $1 \mathrm{~mL}$ etanol $75 \%$ e centrifugado a $7600 \mathrm{rcf}$ por 5 minutos a $4{ }^{\circ} \mathrm{C}$ e repetiu esse processo 3 vezes. Após a última lavagem, o etanol foi retirado e o tubo mantido invertido sobre a bancada até a secagem total do pellet. Finalmente, $25 \mu \mathrm{L}$ de água ultrapura foram adicionados. A concentração do RNA total purificado foi determinada em espectrofotômetro a 260/280 nm (NanoDrop 2000, ThermoFisher). Para a síntese de cDNA, foi realizada uma reação de transcrição reversa a partir do RNA total purificado. Para tanto, $2 \mu \mathrm{g}$ de RNA diluídos em $5 \mu \mathrm{L}$ foram adicionados a $5 \mu \mathrm{L}$ de mix (2 $\mu \mathrm{L} R T$ buffer, $2 \mu \mathrm{L}$ de $\mathrm{RT}$ randomprimers, $1 \mu \mathrm{L}$ de multiscribe e $0,8 \mu \mathrm{L}$ de dNTPs e 4,2 $\mu \mathrm{L}$ de água ultrapura). A mistura foi levada ao termociclador Quant Studio, (Applied Biosystems) e submetida a três ciclos $\left(25^{\circ} \mathrm{C}\right.$ por $10^{\prime} ; 37^{\circ} \mathrm{C}$ por $120^{\prime}$; e $85^{\circ} \mathrm{C}$ por $\left.5^{\prime}\right)$. Decorridos os ciclos, foram adicionados $80 \mu \mathrm{L}$ de água ultrapura.

\subsection{Quantificação por PCR em Tempo Real}

A partir do cDNA obtido, foi avaliada a expressão de mRNA de moléculas envolvidas na inflamação e de células Th1, Th17 e Tregs por PCR em tempo real (qPCR). A cada reação de PCR foi adicionado $0,5 \mu \mathrm{L}$ de $20 x$ TaqMan $\AA$ gene expression assay, 4,5 $\mathrm{L}$ de $2 x$ TaqMan ${ }^{\circledR}$ gene expression assay mastermix, $5 \mu \mathrm{L}$ de amostra de cDNA. As soluções foram levadas ao aparelho Quant Studio3 (Applied Biosystems) e submetidas a diferentes estágios $\left(1,50{ }^{\circ} \mathrm{C}\right.$ por 2'; $2,95^{\circ} \mathrm{C}$ por 2'; $3,95^{\circ} \mathrm{C}$ por $15^{\prime \prime}$ e $60^{\circ} \mathrm{C}$ por 1 ' x 40 repetições). As curvas foram normalizadas pela expressão da $\beta$-actina. $A$ expressão gênica foi dada pela fórmula $2^{-\Delta \Delta \mathrm{Ct}}$, onde $\Delta \Delta \mathrm{Ct}=\Delta \mathrm{Ct}$ (amostra) $\Delta \mathrm{Ct}$ (calibrador), e $\Delta \mathrm{Ct}$ é $\mathrm{O} \mathrm{Ct}$ do gene alvo subtraído do $\mathrm{Ct}$ do gene 
constitutivo. Abaixo segue a lista dos primers $\operatorname{TaqMan} \AA$, que foram utilizados nos experimentos de PCR em tempo real:

\begin{tabular}{|c|l|}
\hline Ifng & Mm01168134_m1 \\
\hline Tbx21 & Mm00450960_m1 \\
\hline Il17a & Mn00439618_m1 \\
\hline Rorc & Mm01261022_m1 \\
\hline Foxp3 & Mm00475162_m1 \\
\hline Bdnf & Mm00446190_m1 \\
\hline II27 & Mm00461162_m1 \\
\hline Ido & Mm01218005_g1 \\
\hline Actb & Mm0073933_m1 \\
\hline
\end{tabular}

3.8 Obtenção de células mononucleares do sistema nervoso central

Os animais foram sacrificados em câmara de $\mathrm{CO}_{2}$ no pico da doença. $\mathrm{O}$ cérebro e a medula espinhal foram extraídos e colocados em tubo cônico de 50 $\mathrm{mL}$ estéreis e incubados com $2,5 \mathrm{mg} / \mathrm{mL}$ de colagenase $D$ em HBSS com cálcio e magnésio durante 45 minutos a $37^{\circ} \mathrm{C}$. Após esse período, a reação da enzimática foi parada com $15 \mathrm{~mL}$ de HBSS $1 \times$ sem cálcio e magnésio acrescido de $0,5 \mathrm{mM}$ de EDTA e, então, as amostras foram processadas em cellstrainers e centrifugadas a $400 \mathrm{~g}$ por 5 minutos a $4{ }^{\circ} \mathrm{C}$. O pellet foi ressuspendido em $6 \mathrm{~mL}$ de Percoll a $25 \%$. Essa suspensão foi adicionada lentamente sobre $2 \mathrm{~mL}$ de Percoll $75 \%$ em tubos de $15 \mathrm{~mL}$ e centrifugada por 20 minutos a $900 \mathrm{~g}$ a $22{ }^{\circ} \mathrm{C} \mathrm{com}$ freio desligado. O sobrenadante foi descartado e $\mathrm{o}$ anel contendo células mononucleares foi armazenado e lavado com $15 \mathrm{~mL}$ de HBSS 1 x sem cálcio e sem magnésio e centrifugado por 5 minutos, $400 \mathrm{~g} \mathrm{a}$ $4{ }^{\circ} \mathrm{C}$. O pellet foi ressuspendido em $1 \mathrm{~mL}$ de meio RPMI com $10 \%$ SFB e $1 \%$ de penicilina/estreptomicina, contado e plaqueado para CBA, citometria de fluxo com marcação de superfície e marcação intracelular. 


\subsection{Obtenção de células do baço e linfonodos}

Os animais foram sacrificados em câmara de $\mathrm{CO}_{2}$. O baço foi extraído no $7^{0}$ dia pós-imunização e no pico da doença e os linfonodos inguinais, subaxilares e periáorticos foram extraídos apenas no $7^{0}$ dia pós-imunização. Ambos foram processados em cellstrainer e centrifugados a $400 \mathrm{~g}$ por 5 minutos a $4{ }^{\circ} \mathrm{C}$. O pellet dos linfonodos foi ressuspendido em meio RPMI com $10 \%$ SFB e $1 \%$ de penicilina/estreptomicina e plaqueado para CBA $\left(1 \times 10^{6}\right.$ células/poço), citometria de fluxo com marcação intracelular $\left(2 \times 10^{6}\right.$ células/poço) e marcação de superfície $\left(1 \times 10^{6}\right.$ células/poço). Ao pellet dos esplenócitos totais foi adicionado $1 \mathrm{~mL}$ de tampão de lise de hemácias por 2 minutos, no gelo, e em seguida adicionado $15 \mathrm{~mL}$ de meio RPMl e centrifugados a $400 \mathrm{~g}$ por 5 minutos a $4^{\circ} \mathrm{C}$. Por fim, o pellet foi ressuspendido em meio RPMI com $10 \%$ SFB e $1 \%$ de penicilina/estreptomicina e plaqueado para CBA ( $1 \times 10^{6}$ células/poço), citometria de fluxo com marcação intracelular ( $2 \times 10^{6}$ células/poço) e marcação de superfície $\left(1 \times 10^{6}\right.$ células/poço).

\subsection{Análises por citometria de fluxo}

\subsubsection{Análise fenotípica das htMSCs}

As htMSCs foram removidas das placas por tripsinização, lavadas e bloqueadas durante 20 minutos com anticorpos monoclonais anti-CD16/32 da eBioscience ${ }^{\circledR}$ (Fcblock) a $4{ }^{\circ} \mathrm{C}$. Em seguida, foram lavadas e incubadas durante 20 minutos a $4{ }^{\circ} \mathrm{C}$ com anticorpos anti-human conjugados específicos para CD14 (PercP-Cy5.5), CD29 (PE), CD31 (Pacific blue), CD44 (FITC), CD45 (PercP), CD73 (PE-Cy7), CD90 (PercP-Cy5.5), HLA-DR (PE) e HLA-ABC (FITC). Em seguida, as células foram novamente lavadas, centrifugadas a 450 g a $4{ }^{\circ} \mathrm{C}$ por 5 minutos e ressuspendidas em $200 \mu \mathrm{L}$ de MACS buffer. A aquisição dessas células foi através do citômetro de fluxo BD Canto II ( $B D$ Biosciences) e analisadas no software FlowJo 10. 
3.10.2 Avaliação de moléculas de ativação em células dendríticas, macrófagos e microglia

As células dos baços e linfonodos extraídas no $7^{0}$ dia pós-imunização, e as células mononucleadas do SNC extraídas no pico da doença foram plaqueadas $1.10^{6}$ células/poço. Posteriormente, as células foram bloqueadas com anticorpos monoclonais anti-CD16/32 da eBioscience $\Theta$ (Fcblock). Após o bloqueio, as células do baço e linfonodo foram incubadas com anti-mouse F4/80 (BV421), CD11b (APC), CD11c (APC-Cy7), MHC II (PE), CD80 (PercPCy5.5), CD86 (FITC) durante 30 minutos a $4^{\circ} \mathrm{C}$.

As células mononucleares foram incubadas com anti-mouse CD45 (PercP), CD11b (APC), MHC II (FITC) CD80 (PE). Em seguida, as células foram lavadas, centrifugadas a $450 \mathrm{~g}$ a $4^{\circ} \mathrm{C}$ por 5 minutos e ressuspendidas em $200 \mu \mathrm{L}$ de paraformaldeído $1 \%$. A aquisição dessas células foi através do citômetro de fluxo BDLSR Fortessa X20 (BD Biosciences) e analisadas no software FlowJo 10. Como estratégia de gate para análise de moléculas de ativação na microglia (Fig. 3), iniciamos demarcando os singlets (Fig. 3A) e, em seguida, escolhendo as células mononucleadas para o SNC pelos parâmetros de tamanho por granulosidade (Fig. 3B). Dentro das células mononucleadas visualizamos: células negativas para CD11b e com alta expressão de CD45 (linfócitos CD45 high CD11b-); as células positivas para CD11b e com expressão baixa de CD45 (microglia ativada $C D 45^{\text {low }} C D 11 b^{+}$) e as células com alta expressão de CD45 (macrófagos infiltrantes CD45 high CD11+) (Fig. 3C). Dentro da população $C D 45^{\text {low }} C D 11 b^{+}$, observamos a expressão das moléculas CD80 (Fig. 3D) e MHC II (Fig. 3E).

Como estratégia de gate para análise de moléculas de ativação de macrófagos e células dendríticas do baço e linfonodos (Fig. 4) iniciamos demarcando os singlets (Fig. 4A) e, em seguida, escolhendo a população das células apresentadoras de antígenos (APCs) pelos parâmetros de tamanho por granulosidade (Fig. 4B). Dentro da população de APCs visualizamos as células positivas para $\mathrm{F} 4 / 80^{+} \mathrm{CD} 11 \mathrm{~b}^{+}$(Fig. $4 \mathrm{C}$ ) e $\mathrm{MHC} \mathrm{II}^{+} \mathrm{CD} 11 \mathrm{C}^{+}$(Fig. 4D). Dentro 
dessas populações, observamos a expressão das moléculas CD80, MHC II e CD86 (Fig. 4E, F e G).

Figura 3 - Estratégia de Gate utilizada para análise das populações de linfócitos infiltrantes e ativação da microglia no cérebro de animais com EAE tratados ou não com htMSCs. (A) Representa o gate em singlets; (B) Representa o gate na população de células mononucleares; (C) Representa o gate na população de linfócitos (CD45 high CD11b-), na população de macrófagos $\left(C D 45^{\text {high }} C D 11 b^{+}\right)$e na população de microglia $\left(C D 45^{\text {low } C D 11 b+) ; ~(D) ~}\right.$ Representa o gate da expressão da molécula CD80 na população de microglia CD45 ${ }^{\text {low } C D 11 b+C D 80+; ~(E) ~ R e p r e s e n t a ~ o ~ g a t e ~ d a ~ e x p r e s s a ̃ o ~ d a ~ m o l e ́ c u l a ~ d e ~}$ $\mathrm{MHC}$ II na população de microglia CD45 ${ }^{\text {low }} \mathrm{CD} 11 \mathrm{~b}^{+} \mathrm{MHC} \mathrm{II}^{+}$.

$\mathbf{A}$

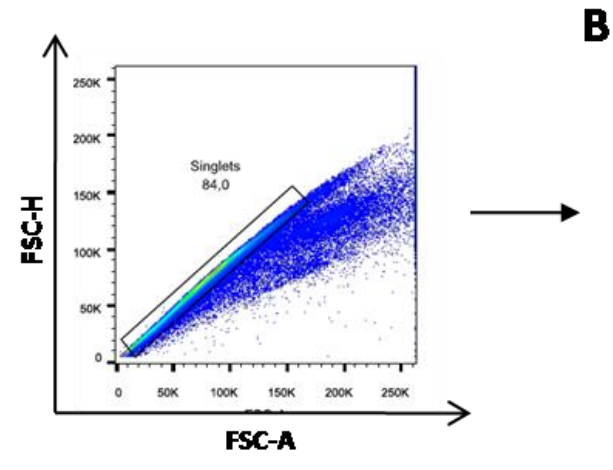

B

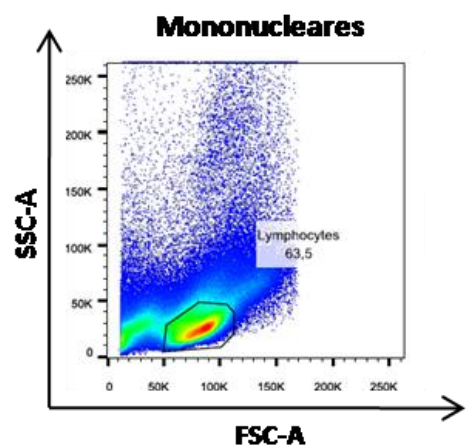

c

$\downarrow$

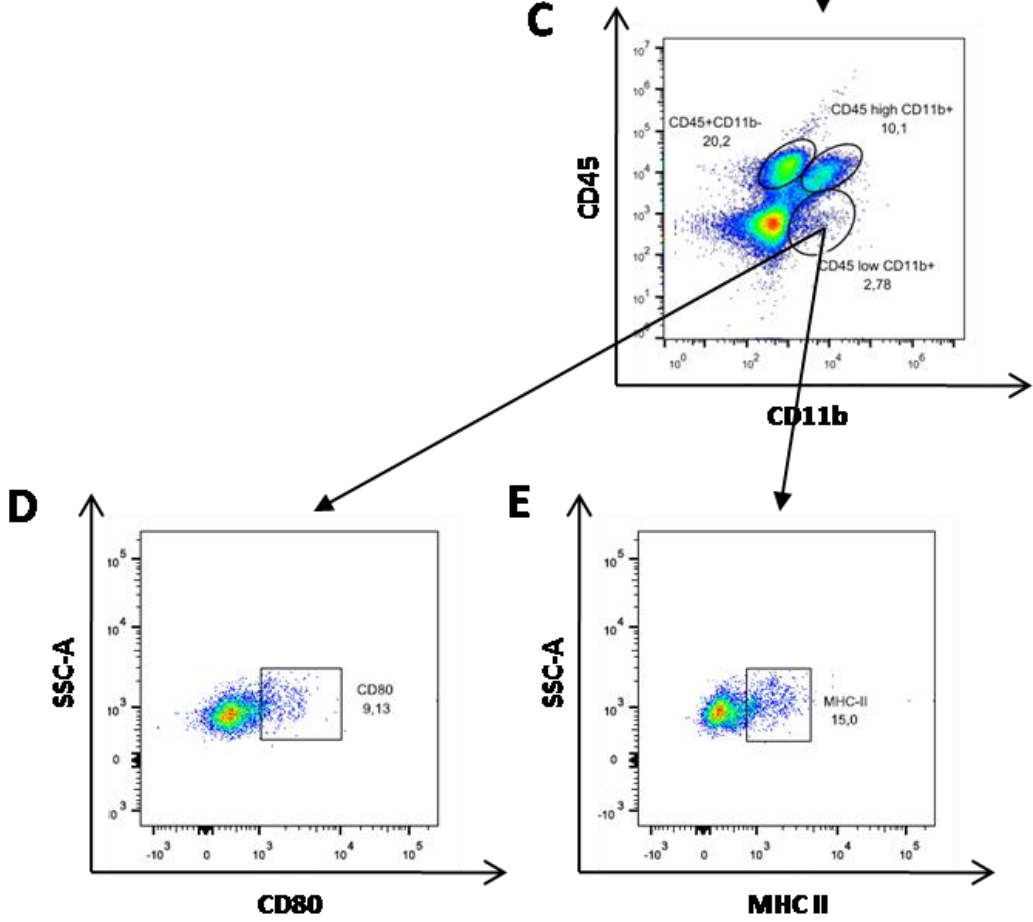


Figura 4 - Estratégia de Gate utilizada para análise da ativação das populações de macrófagos e células dendríticas no baço e linfonodo de animais com EAE tratados ou não com htMSCs. (A) Representa o gate em singlets; (B) Representa o gate na população de APCs; (C) Representa o gate

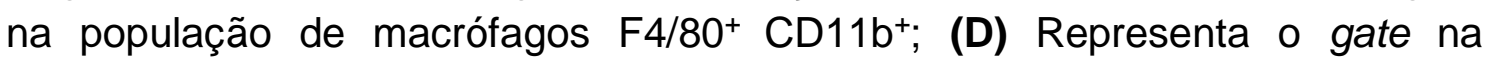
população de células dendríticas $\mathrm{CD} 11 \mathrm{c}^{+} \mathrm{MHC}$ II +; (E) Representa o gate da expressão da molécula CD80, (F) MHC ॥ e (G) CD86 nas populações de macrófagos e células dendríticas.

A

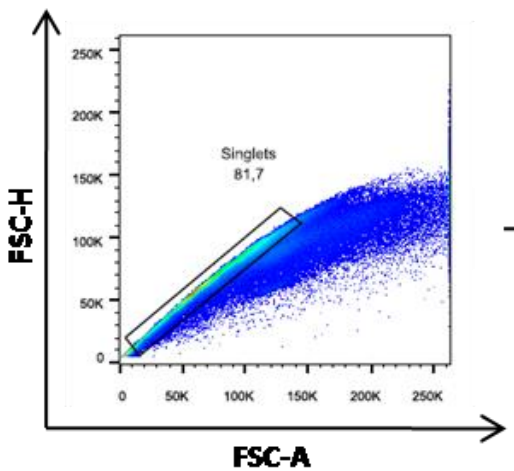

FSC-A
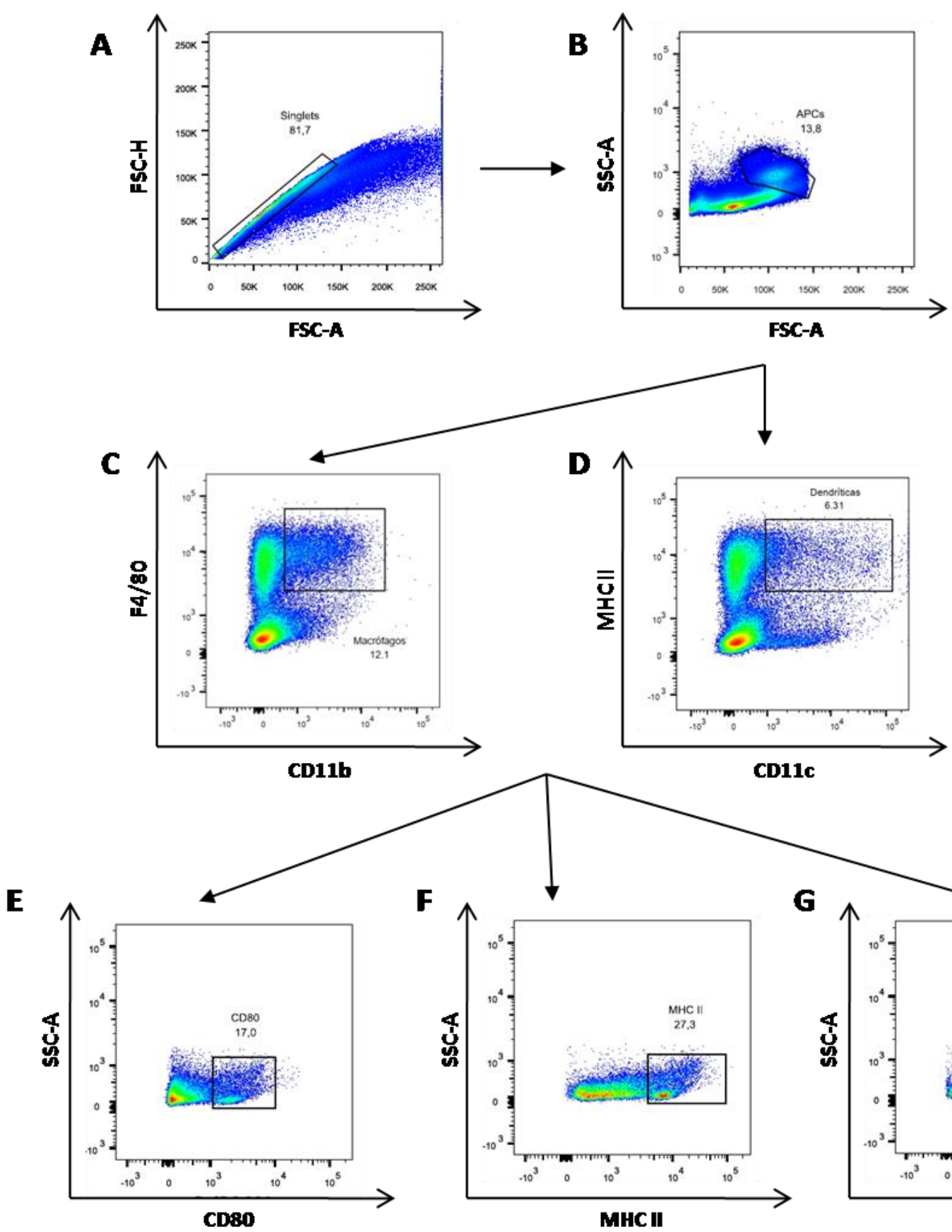

D
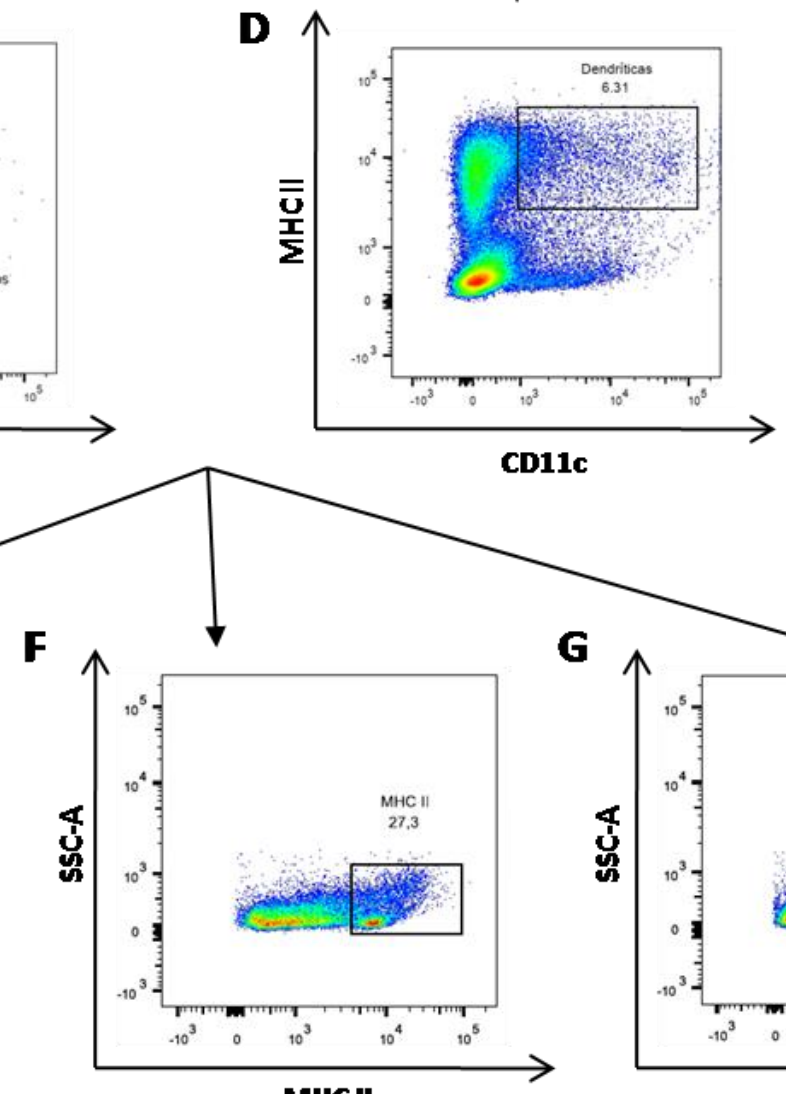

MHC II

G

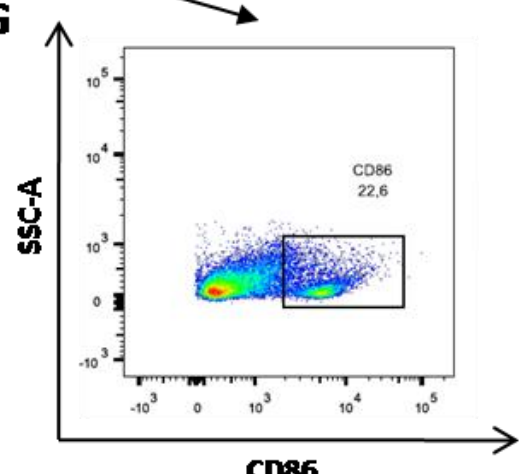


As células dos linfonodos extraídas no $7^{\circ}$ dia pós-imunização, os esplenócitos totais extraídos no $7^{\circ}$ dia pós-imunização e no pico da doença e as células mononucleadas do SNC extraídas no pico da doença foram plaqueadas $1.10^{6}$ células/poço e estimuladas ou não com $\mathrm{MOG}_{35-55}(50 \mu \mathrm{g})$ overnight. Após esse período, as células foram estimuladas ou não PMA (50 $\mathrm{ng} / \mathrm{mL})$ + lonomicina $(1 \mu \mathrm{g} / \mathrm{mL})$ e todas as células foram acrescidas de brefeldina $A(1 \mu \mathrm{g} / \mathrm{mL})$. Posteriormente, as células foram bloqueadas com anticorpos monoclonais anti-CD16/32 da eBioscience ${ }^{\circledR}$ (Fcblock), lavadas e incubadas com anti-mouse CD4 (FITC) e CD8 (PerCP) durante 30 minutos a $4^{\circ} \mathrm{C}$. Para a avaliação das citocinas intracelulares, com o objetivo de caracterizar as populações de linfócitos $T$, as células foram ressuspendidas em $100 \mu \mathrm{L}$ de Cytofix/Cytoperm kit (eBioscience®) e incubadas por 20 minutos a $4^{\circ} \mathrm{C}$. Em seguida, foram lavadas com $100 \mu \mathrm{L}$ de BD Perm/WashTM e centrifugadas a $450 \mathrm{~g}$ a $4^{\circ} \mathrm{C}$ por 5 minutos. Após este processo, as células foram incubadas com o coquetel de anticorpos anti-mouse IFN- y (APC), IL-17 $(P E)$ por 20 minutos. Em seguida, as células foram novamente lavadas, centrifugadas a $450 \mathrm{~g}$ a $4{ }^{\circ} \mathrm{C}$ por 5 minutos e ressuspendidas em $200 \mu \mathrm{L}$ de MACS buffer. A aquisição dessas células foi através do citômetro de fluxo BDLSRFortessa (BD Biosciences) e analisadas no software FlowJo 10.

Como estratégia de gate na marcação intracelular para análise de linfócitos, iniciamos demarcando os singlets (Fig 5A) e, em seguida escolhendo as células mononucleadas para o SNC e linfócitos para baço e linfonodos pelos parâmetros de tamanho por granulosidade (Fig. 5B). Dentro das células mononucleadas ou dos linfócitos visualizamos as células positivas para CD8 e CD4 (Fig. 5C). Dentro de CD4, observamos a população CD4+IL-17A+ (Fig. 5D) e CD4+IFN- $\gamma^{+}$(Fig. 5E). 
Figura 5 - Estratégia de Gate utilizada para análise de expressão de linfócitos e de citocinas intracelulares no baço, linfonodo e cérebro de camundongos com EAE tratados ou não com htMSCs. (A) Representa 0 gate em singlets; (B) Representa o gate em linfócitos/mononucleares; (C) Representa o gate na população de linfócitos T CD8 ${ }^{+}$e linfócitos $\mathrm{T} \mathrm{CD4} 4^{+}$; (D) Representa o gate na população de linfocitos T CD4+ IL-17+; (E) Representa 0 gate na população de linfócitos T CD4+ IFN- $\gamma^{+}$.
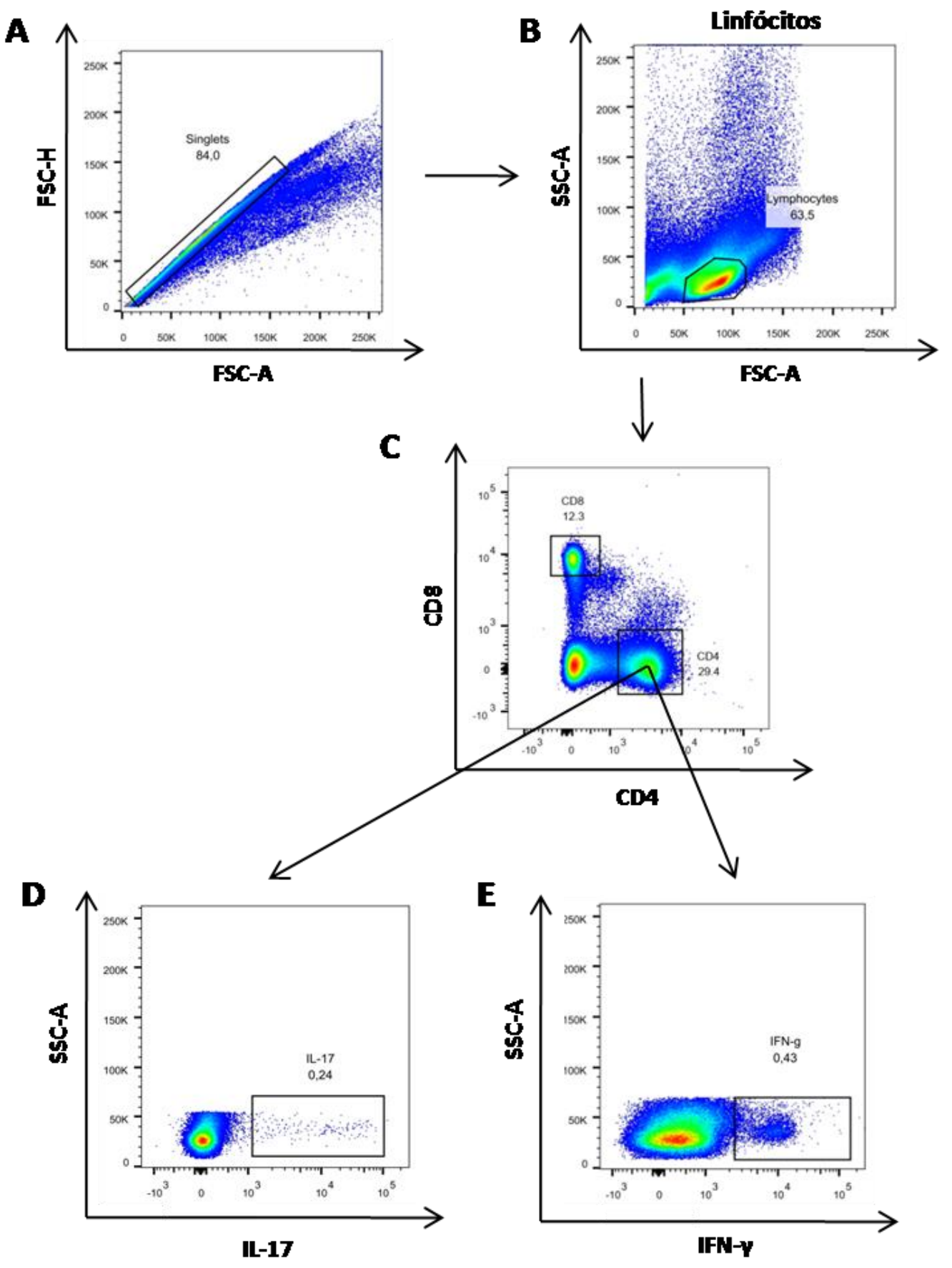


\subsubsection{Dosagem de citocinas}

Os esplenócitos totais, as células dos linfonodos obtidos no $7^{\circ}$ dia e no pico da doença, e as células mononucleadas do SNC foram plaqueadas $1.10^{6}$ células/poço e estimuladas ou não com MOG $35-55$ (50 $\mu \mathrm{g})$; $\alpha$-CD3 $(1 \mu \mathrm{g} / \mathrm{mL})$. Após 72 horas de cultivo o sobrenadante foi coletado para análise do perfil de citocinas através da técnica de CBA. Para a quantificação das citocinas IL-2, IL-4, IL-6, IFN- - , TNF- $\alpha$, IL-17A e IL-10 foi utilizado o CBA Mouse Th1/Th2/Th17 Cytokine Kit da (BD Pharmingen®) conforme instruções do fabricante. As amostras foram adquiridas no aparelho de citometria de fluxo FACS Accuri $B D \otimes$ sendo adquiridos 2100 eventos de acordo com protocolo do fabricante.

\subsection{Histologia}

Realizamos a análise histológica nas medulas espinhais dos animais com EAE tratados ou não com as $h t M S C s(\mathrm{n}=5)$. Os órgãos foram fixados em paraformaldeído $4 \%$ (Sigma-Aldrich) durante 72 horas a $4{ }^{\circ} \mathrm{C}$. Em seguida, foram lavados em água corrente por 10 minutos e a desidratação foi realizada pela imersão dos órgãos em concentrações crescentes de álcool etanol durante 1 hora cada, iniciando pela concentração de $70 \%, 80 \%$, 90\% e por último, duas vezes em etanol 100\%. A partir disso, os órgãos foram imersos em xilol duas vezes durante 1 hora cada e os tecidos foram incluídos em parafina líquida a $60{ }^{\circ} \mathrm{C}$ (Histotec - Merck Chemicals) durante 16 horas. Após polimerização da parafina, os órgãos foram cortados em aproximadamente 5 $\mu \mathrm{m}$ em micrótomo automático Leica RM2165 (leica, Welzear, Alemanha). Os cortes foram assentados em lâminas histológicas e deixadas a $60^{\circ} \mathrm{C}$ por 16 horas para melhor fixação das amostras e evaporação da parafina.

\subsubsection{Coloração por Hematoxilina e Eosina}

As lâminas histológicas foram desparafinizadas com imersão em xilol duas vezes durante 1 hora cada, seguido da hidratação do tecido, iniciando pela imersão em álcool etanol $100 \%, 95 \%$ e $70 \%$ por 10 minutos cada e por 
uma imersão em água destilada durante 5 minutos. A coloração iniciou-se com a Hematoxilina de Harris (Sigma - Aldrich) por 1 minuto seguido de 10 minutos de água corrente, assim removendo o excesso de corante. Em seguida, as lâminas foram coradas com Eosina (Sigma - Aldrich) por 3 minutos e desidratadas com etanol $95 \%$ e duas imersões de 5 minutos cada de etanol $100 \%$. As fotos foram tiradas em aumento de 20x em microscópio de varredura (Leo 435 VP - Zeiss, Oberkochen, Germany).

\subsubsection{Coloração por Luxol Fast Blue}

As lâminas foram desparafinizadas com imersão em xilol duas vezes durante 1 hora cada, seguido da hidratação do tecido, iniciando pela imersão em álcool etanol 100\%, 95\% e 70\% por 10 minutos cada e por uma imersão em água destilada durante 5 minutos. A coloração iniciou-se com solução Luxol Fast Blue (MBS - 0,1 g em etanol 95\%) overnight em estufa a $56^{\circ} \mathrm{C}$. O excesso de corante foi retirado com álcool 95\% no dia seguinte e, posteriormente, as lâminas foram lavadas em água destilada e diferenciadas em solução de carbonato de lítio a $0,05 \%$ por 30 segundos. As fotos foram tiradas em aumento de 4x, 10x, e 20x em microscópio de varredura (Leo 435 VP - Zeiss, Oberkochen, Germany).

\subsection{Síntese de cDNA para PCR Array}

Para a síntese de cDNA foi utilizado o kit $R T^{2}$ First Strand (Qiagen). Para cada amostra, $2 \mu \mathrm{g}$ de RNA foi adicionado a $2 \mu$ de tampão $5 x$ de eliminação de DNA genômico e água livre de RNase para um volume final de $10 \mu \mathrm{l}$. A reação foi incubada a $42^{\circ} \mathrm{C}$ por $10 \mathrm{~min}$, e em seguida colocada rapidamente no gelo por pelo menos 1 minuto. A mistura de transcrição reversa foi preparada com $4 \mu \mathrm{l}$ de tampão (5x Buffer BC3), $2 \mu \mathrm{l}$ da mistura da enzima (RE3 Reverse Transcriptase Mix), $1 \mu \mathrm{l}$ de controle para primer (Control P2) e $3 \mu \mathrm{l}$ de água livre de RNase. Esta mistura foi adicionada aos $10 \mu$ da reação para eliminação de DNA genômico e incubado a $42^{\circ} \mathrm{C}$ por $15 \mathrm{~min}$. Em seguida foi incubado a $95^{\circ} \mathrm{C}$ por 5 min para bloqueio da reação. Após a incubação, foram adicionados $91 \mu \mathrm{l}$ de água livre de RNase e a mistura foi estocada a $-20^{\circ} \mathrm{C}$ até 
ser realizado o PCR array. Todo o protocolo foi seguido conforme as instruções do fabricante.

\subsection{PCR Array}

Para a realização da $R T^{2} P C R$ Array (Qiagen) foi realizada previamente a transcrição reversa para a síntese de cDNA. O $R T^{2}$ Profiler PCR Array (Qiagen) é uma combinação da técnica de reação em cadeia de polimerase em tempo real (qPCR) e microarranjo que analisam vários genes simultaneamente. Para este trabalho foi utilizada a placa Mouse Innate \& Adaptive Immune Responses (PAM-052ZA, Qiagen) representada no Quadro 1.

Quadro 1 - Genes representados na placa Mouse Innate \& Adaptative Immune Responses PCR Array.

\begin{tabular}{|c|c|c|c|c|c|c|c|c|c|c|c|}
\hline $\begin{array}{c}\mathrm{A} 1 \\
\text { Apcs }\end{array}$ & $\begin{array}{l}\text { A2 } \\
\text { C3 }\end{array}$ & $\begin{array}{c}\text { A3 } \\
\text { C5ar1 }\end{array}$ & $\begin{array}{c}\text { A4 } \\
\text { Casp1 }\end{array}$ & $\begin{array}{c}\text { A5 } \\
\text { Ccl12 }\end{array}$ & $\begin{array}{c}\text { A6 } \\
\text { Ccl5 }\end{array}$ & $\begin{array}{c}\text { A7 } \\
\text { Ccr4 }\end{array}$ & $\begin{array}{c}\text { A8 } \\
\text { Ccr5 }\end{array}$ & $\begin{array}{c}\text { A9 } \\
\text { Ccr6 }\end{array}$ & $\begin{array}{l}\text { A10 } \\
\text { Ccr8 }\end{array}$ & $\begin{array}{l}\text { A11 } \\
\text { Cd14 }\end{array}$ & $\begin{array}{l}\mathrm{A} 12 \\
\mathrm{Cd4}\end{array}$ \\
\hline B1 & B2 & B3 & B4 & B5 & B6 & B7 & B8 & B9 & B10 & B11 & B12 \\
\hline $\mathrm{Cd} 40$ & Cd4Olg & Cd80 & Cd86 & Cd8a & Crp & Csf2 & Cxcl10 & Cxr3 & $D d x r 8$ & Fasl & Foxp3 \\
\hline $\mathrm{C} 1$ & $\mathrm{C} 2$ & $\mathrm{C} 3$ & $\mathrm{C} 4$ & C5 & $\mathrm{C} 6$ & $\mathrm{C} 7$ & $\mathrm{C} 8$ & $\mathrm{C9}$ & $\mathrm{C} 10$ & $\mathrm{C} 11$ & C12 \\
\hline Gata3 & $H 2-Q 10$ & H2-T23 & Icam1 & Ifna2 & Ifnar1 & Ifnb1 & Ifng & Ifngr1 & 1110 & $1 / 13$ & $/ / 17 a$ \\
\hline $\mathrm{D} 1$ & D2 & D3 & D4 & D5 & D6 & D7 & D8 & D9 & D10 & D11 & D12 \\
\hline I/18 & $1 / 1 a$ & $/ / 1 b$ & $\| / 1 r 1$ & 112 & II23a & $\| 4$ & 115 & 116 & Irak1 & Irf3 & Irf7 \\
\hline $\mathrm{E} 1$ & E2 & E3 & $\mathrm{E} 4$ & E5 & E6 & E7 & E8 & E9 & E10 & E11 & $\mathrm{E} 1$ \\
\hline Itgam & Jak2 & Ly96 & Lyz2 & Mapk1 & Mapk8 & Mbl2 & Mpo & $M \times 1$ & Myd88 & Nfkb1 & Nfkbia \\
\hline $\mathrm{F} 1$ & F2 & F3 & F4 & F5 & F6 & F7 & F8 & F9 & F10 & $\mathrm{F} 11$ & $\mathrm{~F} 12$ \\
\hline Nlrp3 & Nod1 & Nod2 & Rag1 & Rorc & Slc11a & Stat1 & Stat 1 & Stat 3 & Stat6 & TBx21 & Ticam 1 \\
\hline G1 & G2 & G3 & G4 & G5 & G6 & G7 & G8 & G9 & G10 & G11 & G12 \\
\hline Tlr1 & Tlr2 & TIr3 & TIr4 & Tlr5 & TIr6 & TIr7 & TIr8 & Tlr9 & Tnf & Traf6 & Tyk2 \\
\hline $\mathrm{H} 1$ & $\mathrm{H} 2$ & $\mathrm{H} 3$ & $\mathrm{H} 4$ & $\mathrm{H} 5$ & $\mathrm{H} 6$ & $\mathrm{H} 7$ & $\mathrm{H} 8$ & H9 & $\mathrm{H} 10$ & $\mathrm{H} 11$ & $\mathrm{H} 12$ \\
\hline Actb & $\mathrm{B} 2 \mathrm{~m}$ & Gapdh & Gusb & Hsp90a & MGDC & RTC & RTC & RTC & PPC & PPC & PPC \\
\hline
\end{tabular}

Nesta placa estão incluídos 84 genes envolvidos em vias do sistema imune inato e adaptativo, cinco controles endógenos, um controle de eliminação de DNA genômico, três controles de transcrição reversa, três controles positivos da PCR. Para a realização do PCR Array foi utilizado o kit 
$R T^{2}$ SYBR Green Mastermix do próprio fabricante da placa de PCR Array (Qiagen). O reagente para detecção utilizado foi o $S Y B R$ Green, que é um corante composto por uma molécula que emite fluorescência ao intercalar com DNA de dupla fita. Para preparar a mistura da reação de qRT PCR foram utilizados $1350 \mu \mathrm{l}$ do "2x $R T^{2}$ SYBR Green Mastermix", $102 \mu \mathrm{l}$ da síntese de cDNA e $1248 \mu$ de água livre de RNase. Foi utilizada a placa de 96 poços, e em cada poço foram adicionados $25 \mu \mathrm{l}$ da mistura.O equipamento utilizado para detectar a expressão gênica foi o Quant Studio3 (Applied Biosystems) e as condições dos ciclos foram: um ciclo a $95^{\circ} \mathrm{C}$ por 10 minutos, 40 ciclos a $95^{\circ} \mathrm{C}$ por 15 segundos e $60^{\circ} \mathrm{C}$ por 1 minuto. Cada placa detecta a expressão gênica de uma amostra a ser analisada. As reações foram realizadas com um pool de 10 animais para o grupo controle e 5 animais tratados com htMSCs.

\subsection{Análise dos dados obtidos por PCR Array}

A partir dos resultados obtidos da placa de PCR Array, para comparar a expressão de cada gene foi utilizado o GeneGlobe Data Analysis Center (https://www.qiagen.com/br/shop/genes-and-pathways/data-analysis-center-

overview-page/). A plataforma avaliou os dados e a expressão de cada gene foi calculada em relação aos controles endógenos gliceraldeído 3-fosfato desidrogenase (Gapdh) e proteína de choque térmico (Hsp90ab1). O cálculo da expressão gênica foi realizado pela fórmula $2^{\wedge}(-\Delta \Delta C t)$ que fornece os valores de fold change, ou seja, quantas vezes um gene de um camundongo com EAE tratado com htMSCs é mais ou menos expresso em comparação ao grupo controle.

\subsection{Análises estatísticas}

Todas as análises estatísticas foram realizadas com o auxílio do software Graphpad Prism (Graphpad Software Incorporation) versão 6. As diferenças entre as médias dos resultados que foram obtidos nos experimentos foram determinadas pelo Unpaired $t$ test Student ou análise de variância (ANOVA), dependendo do número de variáveis. T testou ANOVA * $p<0,05 ;{ }^{* *} p$ $<0,01 ;{ }^{* * *} p<0,001 ;{ }^{* * *} p<0,0001$. 


\section{RESULTADOS}

4.1 Isolamento, cultura e análise fenotípica das $h t M S C s$

As amostras de tuba uterina foram obtidas e cultivadas conforme descrito por Jazedje et al., 2009. Após o processamento das amostras, também descrito nos materiais e métodos (3.2), a partir de três dias em cultura, quando é realizada a primeira troca do meio de cultivo, é possível identificar os primeiros nichos de htMSCs (Fig. 6A). Seis dias após o processamento (Fig. $6 \mathrm{~B})$, a cultura torna-se confluente e dá-se início então, a expansão das células.

Para melhor caracterizar essas células e avaliar o potencial multipotente de nossas amostras, ou seja, a capacidade de se diferenciar em outros tecidos, submetemos a cultura primária de htMSCs a diferenciação adipogênica, condrogênica e osteogênica. Na diferenciação adipogênica, podemos observar acúmulo de vesículas ricas em lipídeo (Fig. 6 D e E). A diferenciação condrogênica é caracterizada pela presença da matriz extracelular mucopolissacarídica em roxo (Fig. 6 G) e, por fim, a diferenciação osteogênica é evidenciada pelo acúmulo de cálcio demonstrado pela coloração mais escura.

Além da diferenciação multilinhagem, caracterizamos as htMSCs pela expressão de diferentes marcadores de superfície. Como demonstrado na figura 7 e Tabela 1, as células mostram um fenótipo característico de MSC, apresentando alta expressão dos marcadores CD29, CD44, CD73, CD90 e HLA-ABC, e baixa expressão dos marcadores CD14, CD31, CD45 e HLA-DR. Dessa forma, concluímos que as $h t M S C s$ constituem uma população fenotípica característica de MSC para ser utilizada em nossos experimentos. 
Figura 6 - Isolamento, cultura e diferenciação de htMSCs. Amostras de tuba uterina foram processadas para obtenção e isolamento de $h t M S C s$ in vitro. htMSCs cultivadas (A) 3 dias e (B) 6 dias após processamento foram submetidas a diferenciação (C,D e E) Adipogênica, (F e G) Condrogênica e (H e I) Osteogênica. $\mathbf{C}, \mathbf{F}$ e $\mathbf{H}$ representam os controles. Diferenciação Adipogênica (C,D e E) coloração Oil Red; acúmulo de vesículas ricas em lipídeo pode ser observada em vermelho. Diferenciação Condrogênica $(\mathbf{F}$ e G) Azul de Toluidina; observa-se matriz extracelular mucopolissacarídica em roxo. Diferenciação Osteogênica - coloração Alizarin Red; o acúmulo de cálcio é demonstrado pela coloração mais escura (setas).

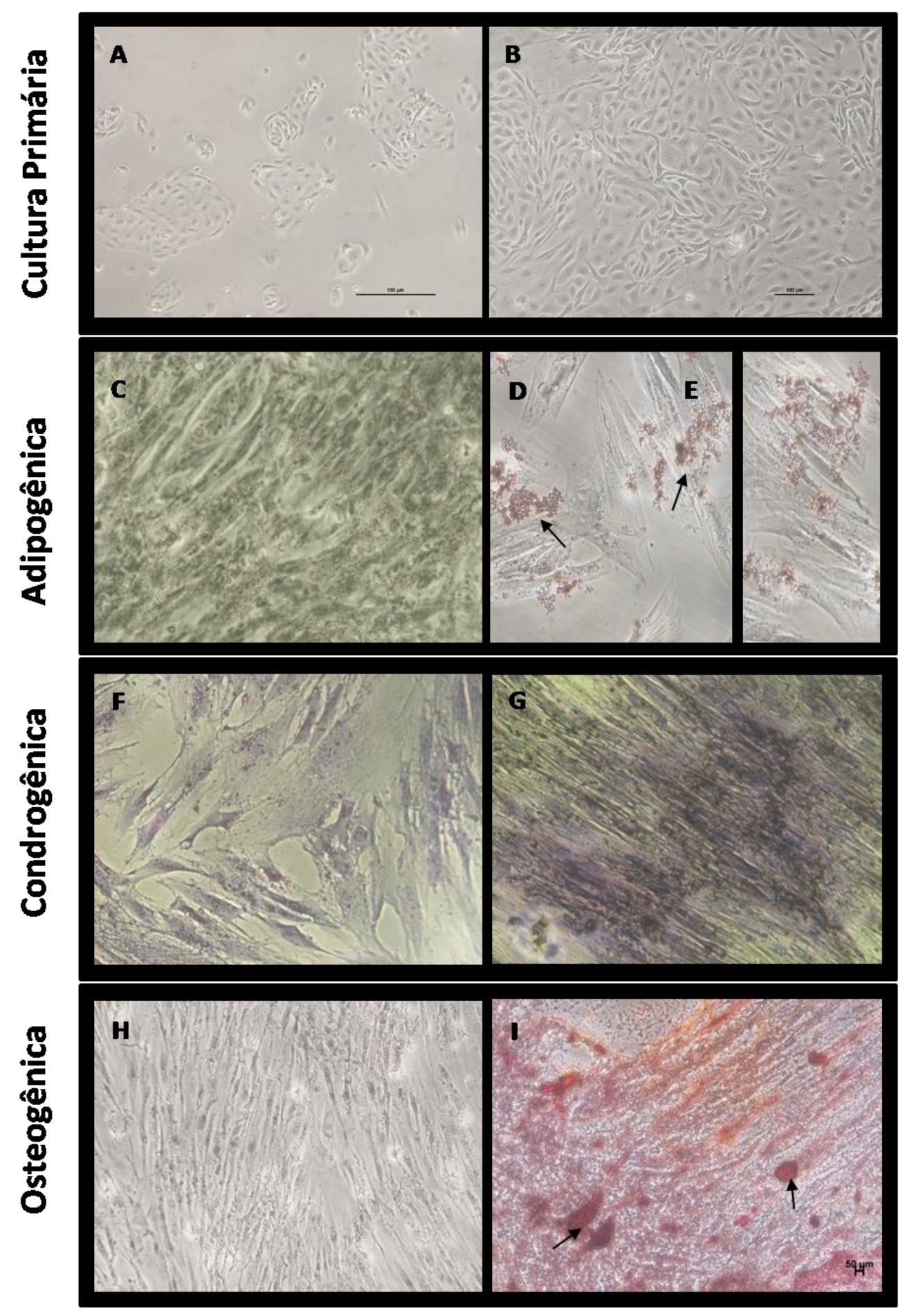


Figura 7 - Caracterização fenotípica das htMSCs. htMSCs obtidas e cultivadas conforme descrito em materiais e métodos foram submetidas a análise por citometria de fluxo para a expressão de CD14, CD29, CD31, CD44, CD45, CD73, CD90, HLA-ABC e HLA-DR. O controle não marcado é representado em vermelho.
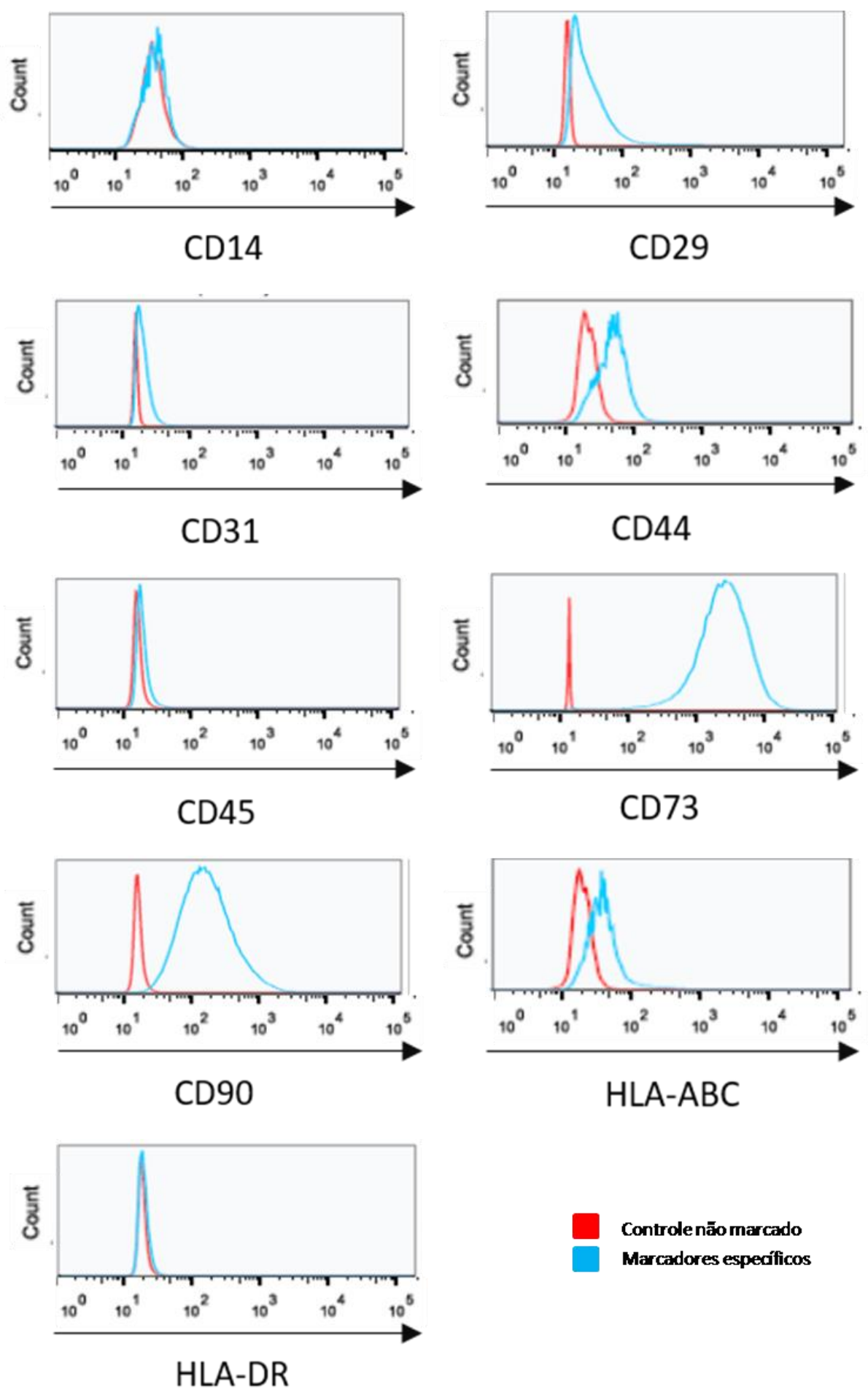

Controlenāo marcado

Marcadores específicos

HLA-DR 
Tabela 1 - Dados numéricos de htMSCs positivas para os marcadores citados na figura 7.

\begin{tabular}{ccc}
\hline Marcadores & Especificidade & \% de células marcadas \\
\hline CD14 & Marcador de monócito & 0,89 \\
CD29 & Marcador específico de MSC/Aderência & 95,47 \\
CD31 & Marcador Endotelial & 3,95 \\
CD44 & Marcador específico de MSC/ Aderência & 94,95 \\
CD45 & Marcador de células tronco hematopoiéticas & 1,68 \\
CD73 & Marcador específico de MSC & 99,69 \\
CD90 & Marcador específico de MSC/Aderência & 98,42 \\
HLA-ABC & MHC de classe I & 94,15 \\
HLA-DR & MHC de classe II & 1,83 \\
\hline
\end{tabular}

4.2 O tratamento com htMSCs reduz o score da EAE in vivo a longo prazo

\subsubsection{As htMSCs são capazes de reduzir a progressão da $E A E$}

Uma vez caracterizadas, nosso próximo passo foi avaliar o efeito modulatório in vivo das htMSCs. Nosso grupo demonstrou que hedMSCs possuem um potente efeito imunomodulatório in vivo (Peron, Jazedje et al. 2012). Para investigar o potencial das $h t M S C s$ de modularem a progressão da EAE in vivo, camundongos C57BL/6 imunizados com MOG $35-55$, conforme descrito em material e métodos (3.4), receberam uma dose de htMSC no mesmo dia da imunização (dia 0 ). Os animais foram acompanhados diariamente e o score clínico foi avaliado até o dia 30.

A figura $8 \mathrm{~A}$ e $\mathrm{B}$ demonstra que os camundongos que receberam $\mathrm{O}$ tratamento com htMSCs apresentaram uma redução bastante significativa no score clínico da EAE durante todo o período. Na tabela 2, podemos observar que o score clínico do grupo tratado é menor do que o do grupo controle na fase inicial do surgimento dos sintomas (dias 10 ao dia 13), no pico da doença (dias 14 a 18) e na fase de remissão (dias 20 a 30), indicando que a as htMSCs foram capazes de diminuir a progressão da doença in vivo. 
Tabela 2 - Média do score clínico de animais com EAE tratados com apenas uma dose de htMSCs no dia 0.

\begin{tabular}{ccc}
\hline Média de Score & Controle & htMSCs \\
\hline Fase Inicial & $1.02 \pm 0,95$ & $0,25 \pm 0,44$ \\
Pico & $3,60 \pm 0,45$ & $2,15 \pm 1,18$ \\
Remissão & $2,80 \pm 0,30$ & $1,12 \pm 0,69$ \\
\hline
\end{tabular}

4.2.2 O tratamento com htMSCs reduz a neuroinflamação e danos histopatológicos no cérebro e medula espinhal de animais com EAE

As medulas espinhais dos animais tratados ou não com $h t M S C s$ foram submetidas aos protocolos de coloração para HE e Luxol Fast blue para análise de infiltrado inflamatório e desmielinização, respectivamente, uma vez que esses achados são característicos do desenvolvimento da EAE. Podemos observar que houve diminuição no infiltrado inflamatório na medula espinhal (Fig. $8 \mathrm{C}$ ) de animais tratados com htMSCs. O mesmo ocorreu quanto à desmielinização, onde observa-se que os animais tratados apresentaram uma menor desmielinização na medula espinhal (Fig. 8 C).

4.2.3 As htMSCs inibem a transcrição de genes pró-inflamatórios dos linfócitos patogênicos e induzem a transcrição de genes imunomodulatórios

Ainda, no 30 dia pós-imunização, as medulas espinhais dos animais tratados ou não com $h t M S C s$ foram obtidas e analisadas quanto à expressão de diversos genes. Observamos que o tratamento com htMSCs diminuiu a expressão dos genes Ifng e $1 / 17$ (Fig. 8 D e F), os quais são relacionados às citocinas produzidas pelas populações de linfócitos $T$ patogênicos Th1 e Th17 na EAE, respectivamente. A expressão dos genes Tbx21 (Fig. 8 E), fator de transcrição das células Th1, e RorC (Fig. $8 \mathrm{G}$ ), fator de transcrição das células Th17 também foram diminuídos.

Observamos também que não houve um aumento significativo na expressão do gene do fator de transcrição de células T reguladoras Foxp3 (Fig. 
$8 \mathrm{H}$ ), na expressão do gene Bdnf (Fig $8 \mathrm{l}$ ), fator neurotrófico envolvido no desenvolvimento e função das células nervosas e do gene II27 (Fig. $8 \mathrm{~J}$ ), fator de transcrição da citocina IL 27, a qual foi descrita recentemente como inibidora de linfócitos Th17. Ainda, o tratamento aumentou a expressão do gene da enzima indoleamina 2,3-dioxigenase (IDO), conhecida por sua função imunomoduladora por limitar a função de células T (Fig 8. K). Com esses resultados, concluímos que as htMSCs possuem um efeito imunomodulatório in vivo na EAE e, que esse efeito ocorre de forma duradoura.

4.2.4 O tratamento com duas doses de htMSCs é mais efetivo em reduzir a progressão da EAE.

A fim de tentar aumentar o efeito imunomodulador observado nas htMSCs, testamos uma estratégia terapêutica na qual os animais receberam a primeira dose de células tronco no dia da imunização (dia 0) e, uma segunda dose, ambas por via intra-peritoneal, no 10ํ dia pós-imunização. De fato, a segunda dose contribuiu para uma maior inibição da progressão da doença (Fig 9 A, B), uma vez que a média do score dos animais tratados com duas doses de htMSCs no pico da doença é menor que a média dos animais tratados com apenas uma dose (Tabela 3).

Tabela 3 - Média do score clínico de animais com EAE tratados com duas doses de $h t M S C s$ nos dias 0 e 10 pós-imunização.

\begin{tabular}{ccc}
\hline Média de Score & Controle & htMSCs \\
\hline Fase Inicial & $1,36 \pm 1,14$ & $0,20 \pm 0,35$ \\
Pico & $3,60 \pm 0,43$ & $1,82 \pm 1,33$ \\
Remissão & $2,82 \pm 0,33$ & $1,45 \pm 0,88$ \\
\hline
\end{tabular}

Finalmente, para avaliarmos se o tratamento teria efeito inibitório se realizado na fase inicial do surgimento dos sintomas, realizamos o tratamento com htMSCs apenas no 10ํ dia pós-imunização. Curiosamente, observamos uma redução não significativa no score dos animais tratados (Fig. 9 C, D) durante todo o percurso da doença (Tabela 4). 
Figura 8 - 0 tratamento com htMSCs reduz o score clínico da EAE in vivo, reduz a neuroinflamação e danos histopatológicos e modula a expressão gênica na medula espinhal. Camundongos $\mathrm{C}$ (BL/6 que receberam MOG 35 $55(150 \mu \mathrm{g} /$ animal) emulsificado em CFA (v/v), contendo M. tuberculosis H37

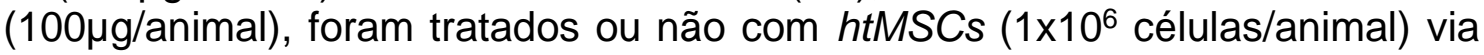
intra-peritoneal no dia 0 . (A) Os animais ( $\mathrm{n}=8$ por grupo) foram analisados em relação ao score clínico da doença diariamente até o dia 30. (B) mostra o valor da área sob a curva do grupo tratado e não tratado. No dia 30 , a medula espinhal foi obtida e corada com (C) HE para analisar células infiltrantes e Luxol fast blue para analisar desmielinização. O mRNA total da da parte distal da medula espinhal foi obtido e analisado por RT-PCR em relação a expressão dos genes (D) Ifng, (E) Tbx21, (F) IIL-17a, (G) Rorc, (H) Foxp3, (I) Bdnb, (J) $1 / 27$ e (K) Ido. Os dados foram normalizados com o gene da $\beta$-actina e comparados ao grupo Controle. Dados representativos de dois experimentos independentes. Análise Estatística T test e Two way ANOVA, ${ }^{*} p<0,05 ;{ }^{* *} p<$ 0,$01 ;{ }^{* * *} p<0,001 e^{* * * *} p<0,0001$ em relação ao controle.

A

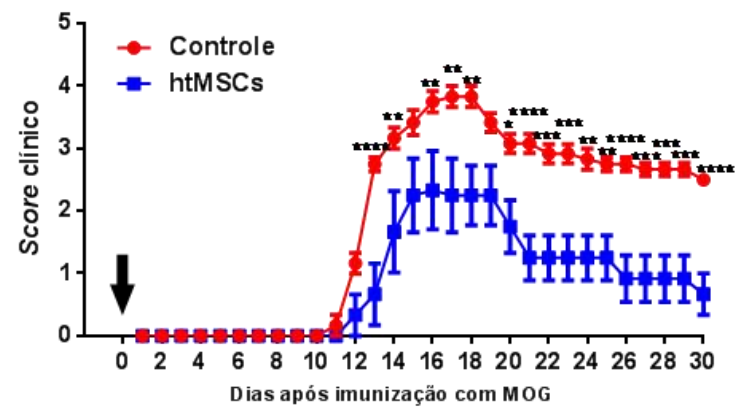

C

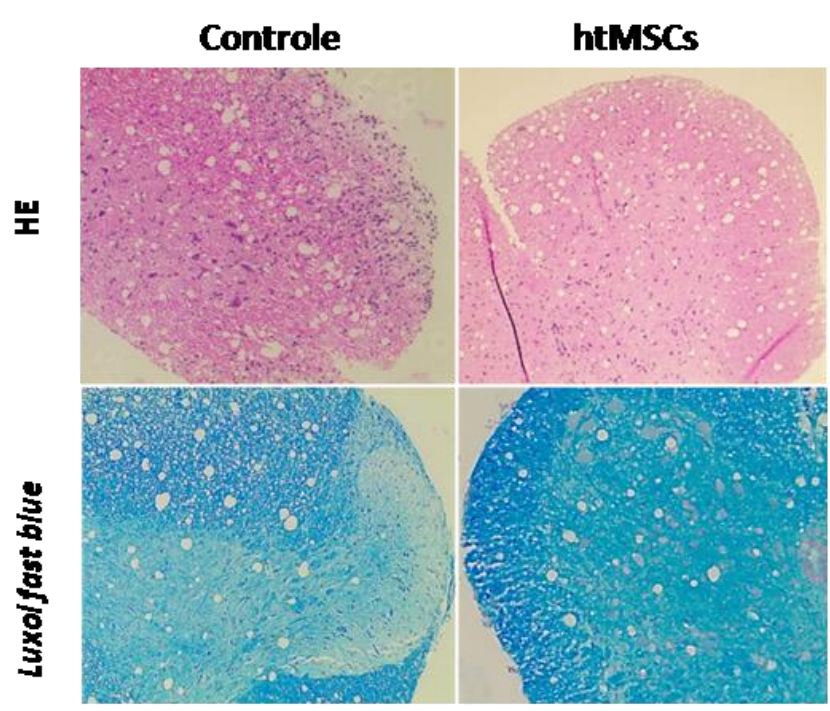

B

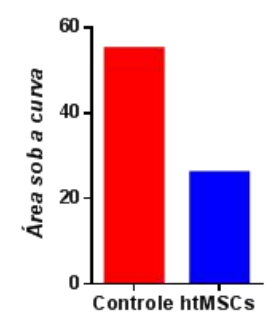

D

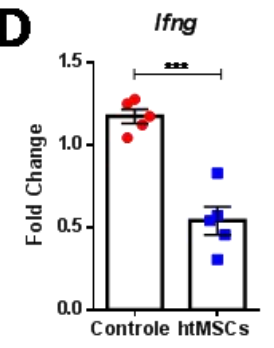

$\mathbf{E}$

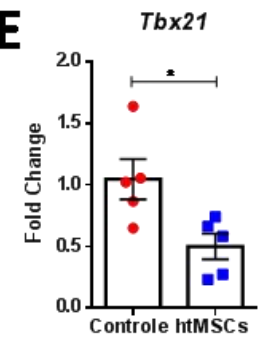

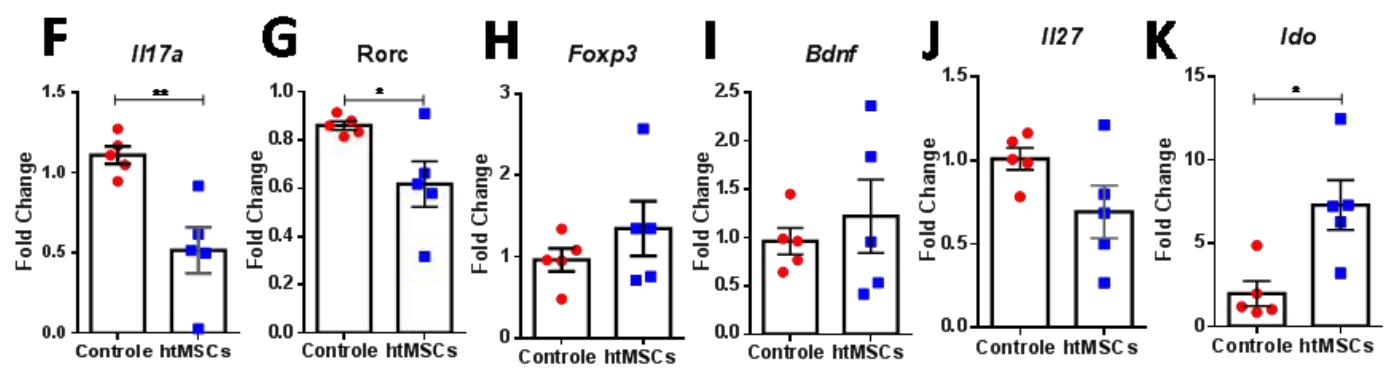


Figura 9 - 0 tratamento com duas doses de $h t M S C s$ é mais efetivo em reduzir o score clínico da EAE in vivo. Camundongos C57BL/6 que

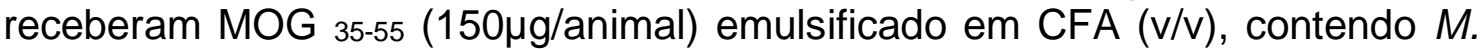

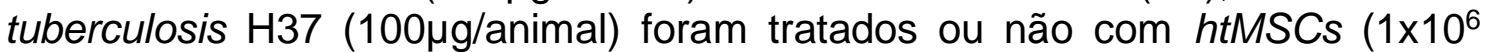
células/animal) via intra-peritoneal no dia 0 e dia 10, ou somente no dia 10. (A, C) Os animais ( $n=10$ por grupo) foram analisados em relação ao score clínico da doença diariamente até o dia 30. (B, D) Mostra o valor da área sob a curva do grupo tratado e não tratado. Dados representativos de dois experimentos independentes. Análise Estatística Two way ANOVA, ${ }^{*} p<0,05 ;{ }^{* *} p<0,01$; $* * *$ $p<0,001 e^{* * * *} p<0,0001$ em relação ao controle.

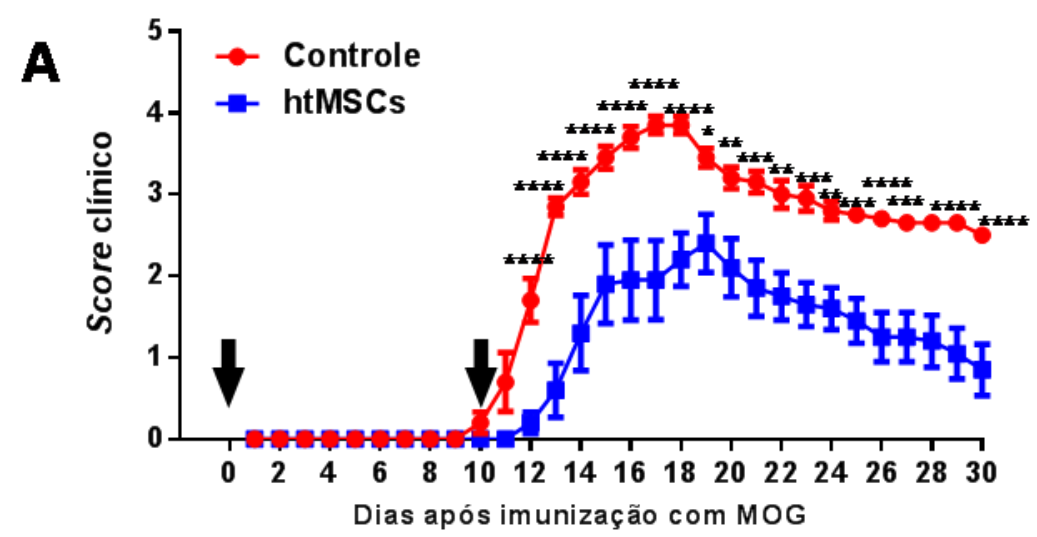

B

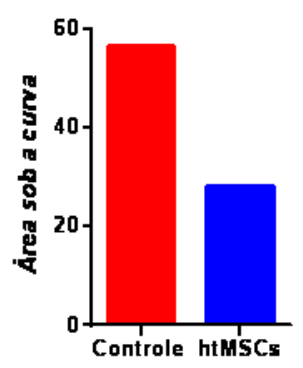

C

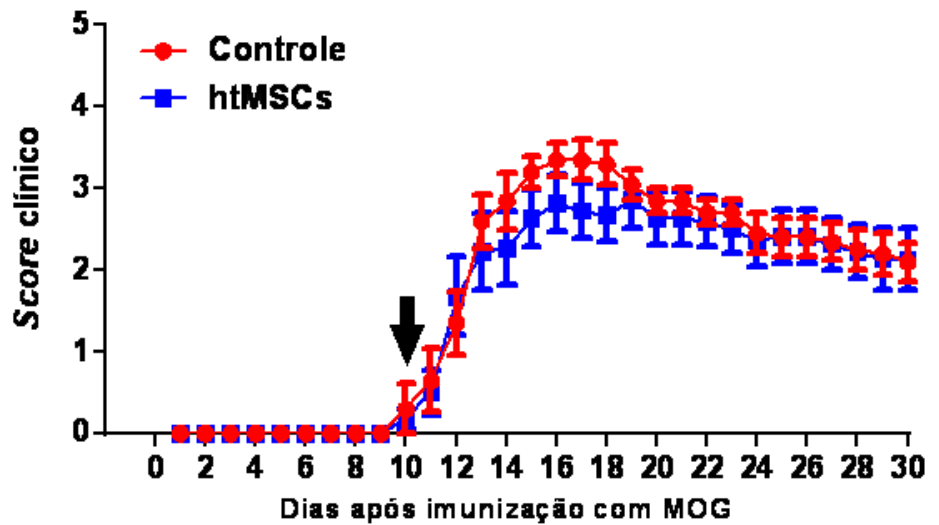

D

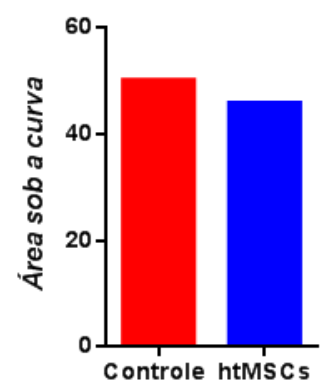


Tabela 4 - Média do score clínico de animais com EAE tratados com apenas uma dose de $h t M S C s$ no dia 10 pós imunização.

\begin{tabular}{ccc}
\hline Média de Score & Controle & $\boldsymbol{h t M S C \boldsymbol { s }}$ \\
\hline Fase Inicial & $1,53 \pm 1,24$ & $1,47 \pm 1,39$ \\
Pico & $3,21 \pm 0,65$ & $2,63 \pm 0,87$ \\
Remissão & $2,48 \pm 0,44$ & $2,40 \pm 0,82$ \\
\hline
\end{tabular}

4.3 Avaliação da Imunomodulação das htMSCs durante o estabelecimento da EAE na periferia

\subsubsection{Perfil de macrófagos e células dendríticas no baço e linfonodo durante o estabelecimento da EAE na periferia}

O desenvolvimento da EM e da EAE ocorre inicialmente por linfócitos T auto-reativos aos epítopos de mielina que são ativados nos tecidos linfáticos periféricos e que, subseqüentemente, infiltram o SNC (Pettinelli and McFarlin 1981). Sendo assim, tivemos interesse em buscar o papel imunomodulatório das htMSCs nos estágios iniciais do estabelecimento da doença na periferia. Para isso, C57BL/6 imunizados com $\mathrm{MOG}_{35-55}$, receberam uma dose de htMSCs no mesmo dia da imunização.

No sétimo dia pós-imunização, foram obtidos os baços e linfonodos inguinais e periaórtico desses animais, os quais foram analisados por citometria de fluxo quanto à frequência e número absoluto das populações de macrófagos $\left(\mathrm{F} 4 / 80^{+} \mathrm{CD} 11 \mathrm{~b}^{+}\right)$e células dendríticas $\left(\mathrm{CD} 11 \mathrm{c}^{+} \mathrm{MHC} \mathrm{II}^{+}\right)$presentes no baço e linfonodos (Fig. 10). No baço, pudemos observar um aumento do tamanho (Fig. 10 A), da massa do órgão (Fig. 10 B) e do número de células totais no baço de animais do grupo tratado (Fig. $10 \mathrm{C}$ ). Quanto às populações das células apresentadoras de antígenos, houve um aumento significativo na frequência de células dendríticas (Fig. 10 E) e macrófagos (Fig. 10 G) no baço dos animais que receberam htMSCs. No linfonodo, por outro lado, não observamos diferença no número de células totais $($ Fig.10 H) ou no número total e frequência de células dendríticas (Fig. $10 \mathrm{I}$ e J) e macrófagos (Fig. $10 \mathrm{~K} \mathrm{e} \mathrm{L).}$ 
Figura 10 - Perfil de células dendríticas e macrófagos no baço e linfonodos de animais com EAE 7 dias pós-imunização. (A) Comparação do tamanho e (B) massa do baço entre o grupo controle e tratado. Células totais do baço (C) e linfonodos inguinais e periaórticos (H) foram obtidas de animais com EAE tratados ou não com $h t M S C s$ no $7^{0}$ dia pós-imunização $(\mathrm{n}=5$ por grupo) e foram submetidas a análise por citometria de fluxo quanto a frequência e número absoluto das populações de células dendríticas $\left(\mathrm{CD} 11 \mathrm{c}^{+}\right.$ $\left.\mathrm{MHC} \mathrm{II}^{+}\right)\left(\mathrm{D}, \mathbf{E}, \mathbf{I}\right.$ e J) e macrófagos $\left(\mathrm{F} 4 / 80^{+} \mathrm{CD} 11 \mathrm{~b}^{+}\right)$(F, G, K e L). Dados representativos de dois experimentos independentes. Análise Estatística $T$ test, ${ }^{*} p<0,05 e^{* * * *} p<0,0001$ em relação ao controle.

\section{Baço}

$\mathbf{A}$

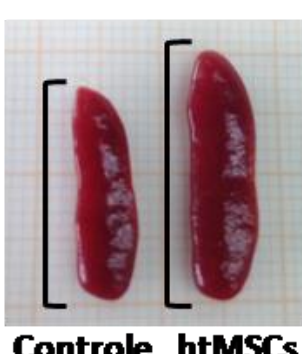

B

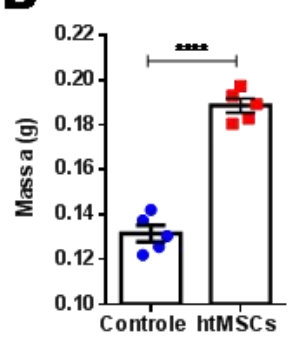

C Células totais do Baço

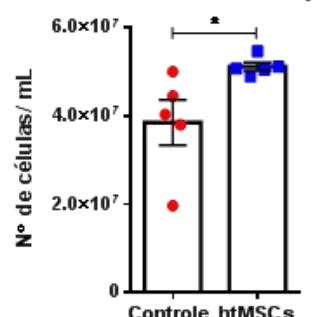

\section{D}

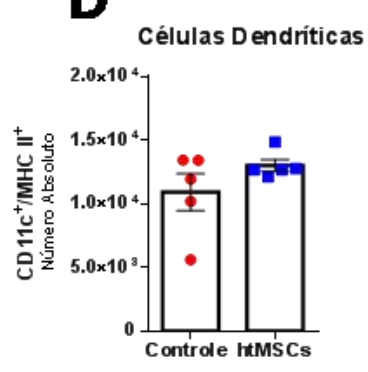

E

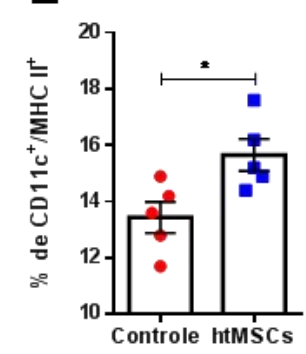

F

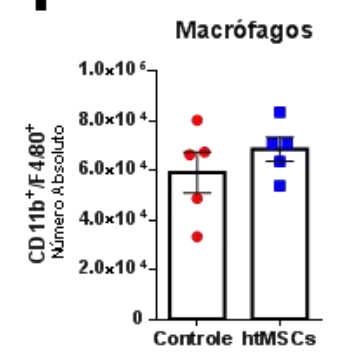

G

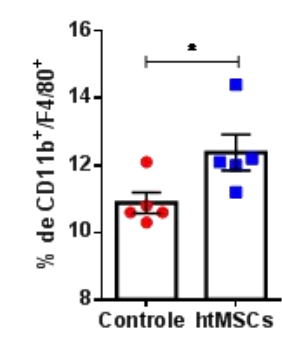

\section{Linfonodo}

H
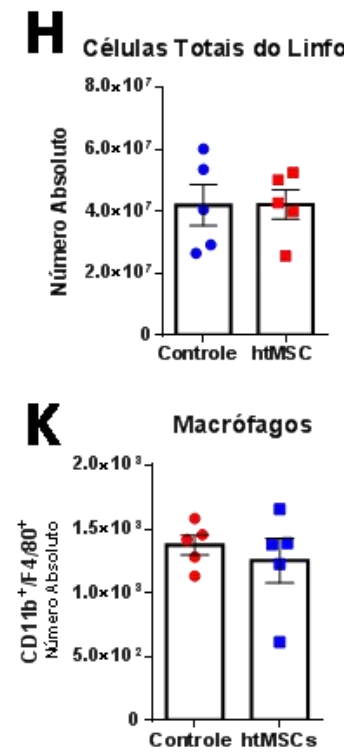

J

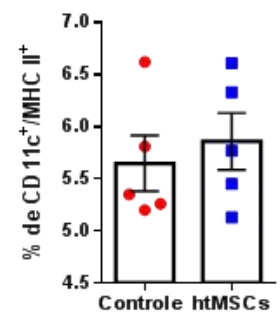

L

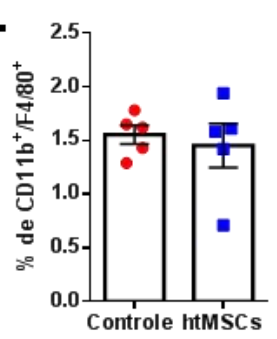


4.3.2 htMSCs modulam a apresentação de antígenos e ativação de macrófagos e células dendríticas no linfonodo de animais no início da EAE

As células apresentadoras de antígenos são imprescindíveis para o início da resposta imune, sendo assim, com o objetivo de verificar se as htMSCs conseguiriam modular a ativação de macrófagos e células dendríticas durante o início da EAE na periferia, analisamos a expressão da molécula de MHC II e das moléculas coestimuladoras CD80 e CD86 dessas células no baço e linfonodo dos animais tratados e não tratados 7 dias pós-imunização.

Nos macrófagos do baço, não observamos modulação na expressão das moléculas CD86 (Fig. 11 A), CD80 (Fig. 11 B) e MHC II (Fig. 11 C). Nos linfonodos, porém, apesar de não alterar a freqüência e número absoluto da população de macrófagos, o tratamento com as $h t M S C s$ foi capaz de modular a expressão de CD86 (Fig. 11 D), CD80 (Fig. 11 E) e MHC II (Fig. 11 F), reduzindo a expressão das mesmas nos animais tratados.

Nas células dendríticas, observamos um efeito maior da modulação das htMSCs, uma vez que tanto as populações de células dendríticas do baço quanto do linfonodo tiveram a expressão das moléculas CD86 (Fig.12 A e D), CD80 (Fig. 12 B e E) e MHC II (Fig. 12 C e F) diminuída no grupo de animais tratados. Podemos concluir, assim, que o tratamento com htMSCs consegue, de alguma forma, modular a apresentação de antígeno e a ativação de células dendríticas no baço e linfonodo dos animais tratados.

4.3.3 htMSCs reduzem a população de linfócitos $T C D 4^{+}$no linfonodo de animais no início da $E A E$

Além de macrófagos e células dentríticas, nos interessamos em analisar as populações de linfócitos $\mathrm{T} \mathrm{CD}^{+}$e $\mathrm{T} \mathrm{CD}^{+}$no baço e linfonodos dos camundongos tratados com htMSCs durante o estabelecimento da EAE. Para isso, os esplenócitos totais e células totais do linfonodo extraídos no $7^{\circ}$ dia pósimunização foram re-estimuladas ou não in vitro com $\mathrm{MOG}_{35-55}$ conforme material e métodos (3.10.3) e analisados por citometria de fluxo em relação a 
Figura 11 - Expressão das moléculas CD86, CD80 e MHC II é reduzida em macrófagos $\left(\mathrm{F} 4 / 80^{+} \mathrm{CD} 11 \mathrm{~b}^{+}\right)$nos linfonodos de animais com $\mathrm{EAE}$ tratados com htMSCs. Células do baço e linfonodos inguinais e periaórticos foram obtidas de animais com EAE tratados ou não com htMSCs no 70 dia pósimunização ( $n=5$ por grupo) e foram submetidas a análise por citometria de fluxo da expressão das moléculas de superfície celular (A, D) CD86, (B, E) CD80 e (C, F) MHC II na população de macrófagos. Dados representativos de dois experimentos independentes. Análise estatística T test ${ }^{*} p<0,05 ;{ }^{* *} p$ $<0,01 ;{ }^{* * *} p<0,001$ em relação ao controle.

\section{Macrófagos Baço}

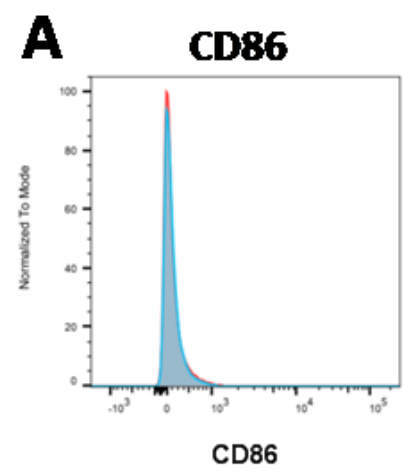

B

CD80

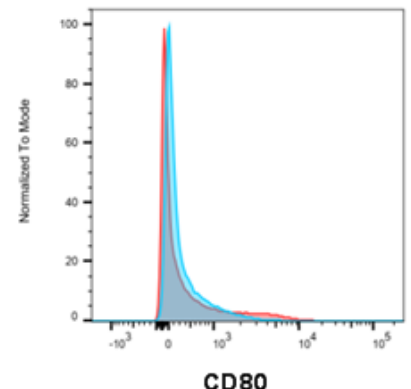

CD80
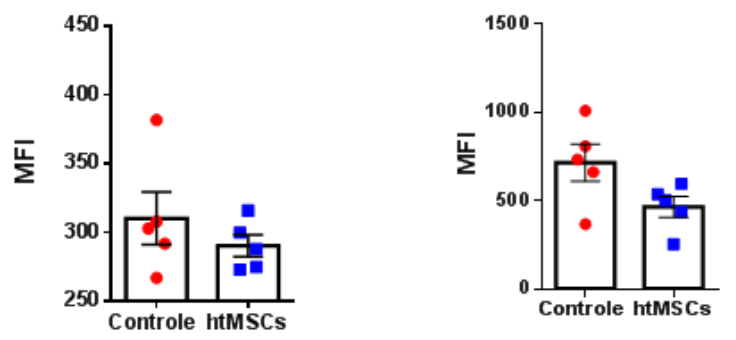

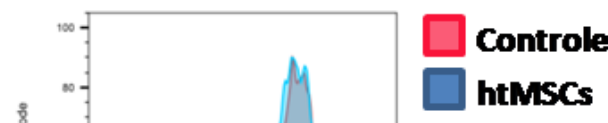

C

MHC II

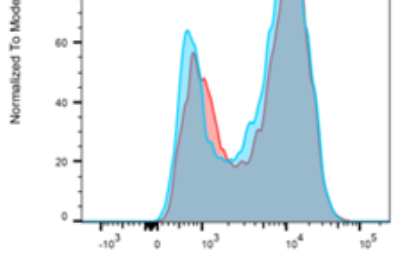

MHC II

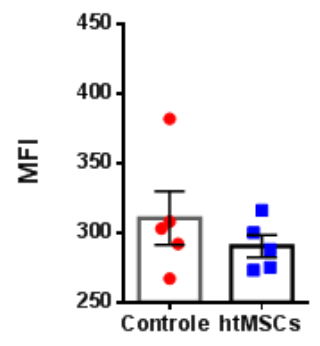

\section{Macrófagos Linfonodo}
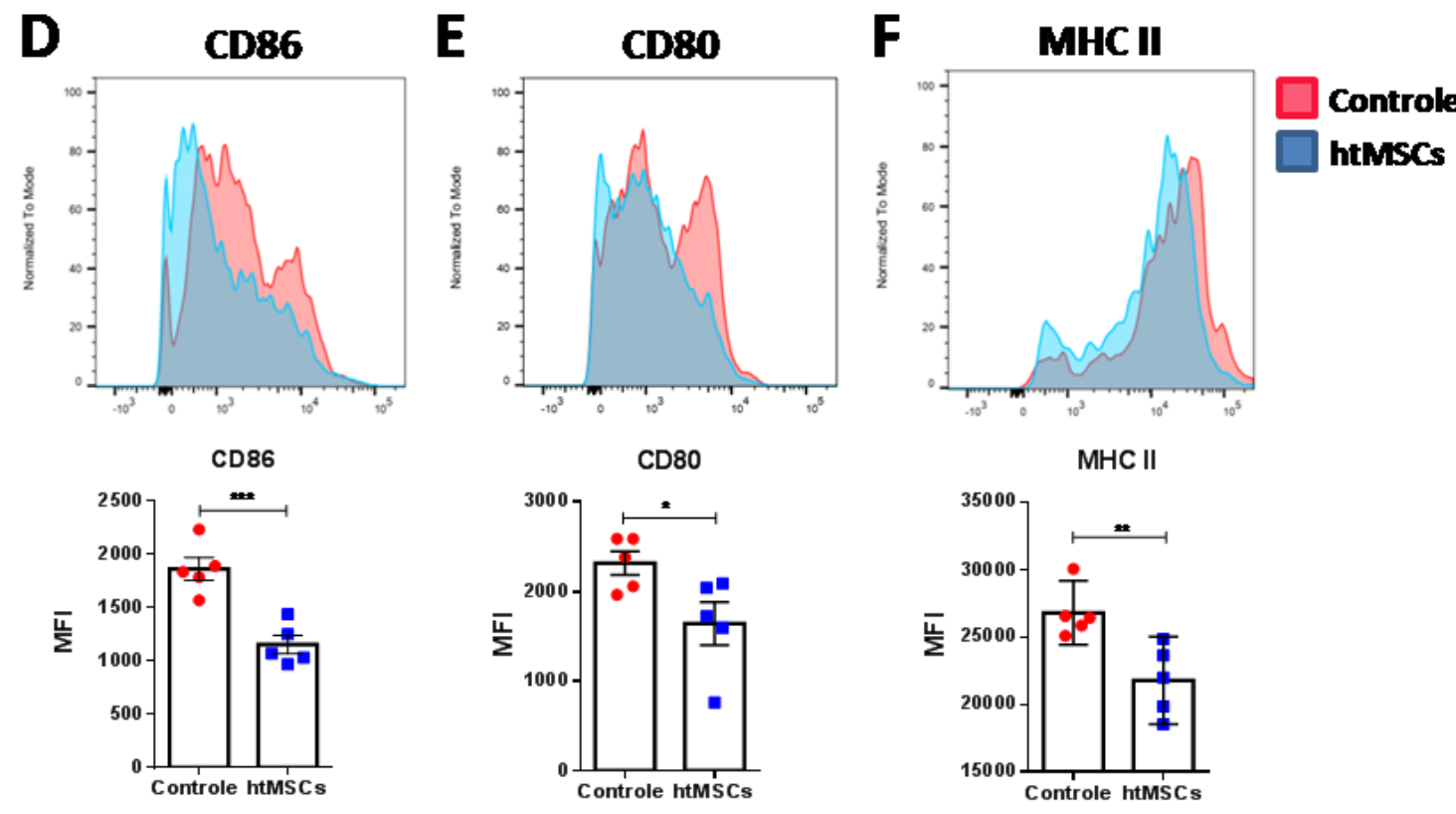
Figura 12 - Expressão das moléculas CD86, CD80 e MHC II é reduzida em células dendríticas (CD11 $\mathrm{c}^{+} \mathrm{MHC} \mathrm{II}^{+}$) nos linfonodos de animais com EAE tratados com htMSCs. Células do baço e linfonodos inguinais e periaórticos foram obtidas de animais com EAE tratados ou não com htMSCs no 70 dia pósimunização ( $n=5$ por grupo) e foram submetidas a análise por citometria de fluxo da expressão das moléculas de superfície celular (A, D) CD86, (B, E) CD80 e (C, F) MHC II na população de células dendríticas. Dados representativos de dois experimentos independentes. Análise estatítica $T$ test * $p<0,05 ;{ }^{* *} p<0,01$ em relação ao controle.

\section{Dendríticas Baço}

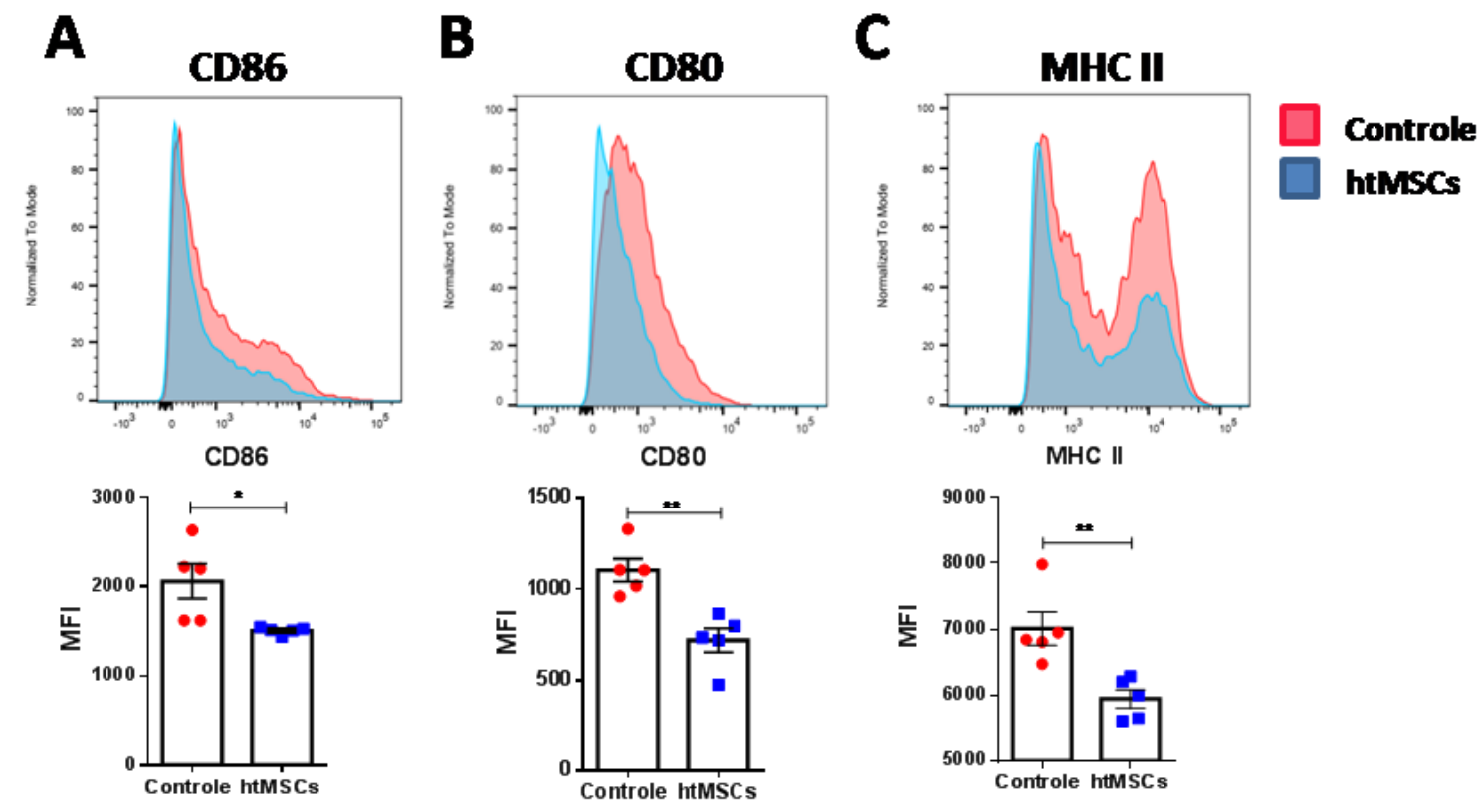

\section{Dendríticas Linfonodo}
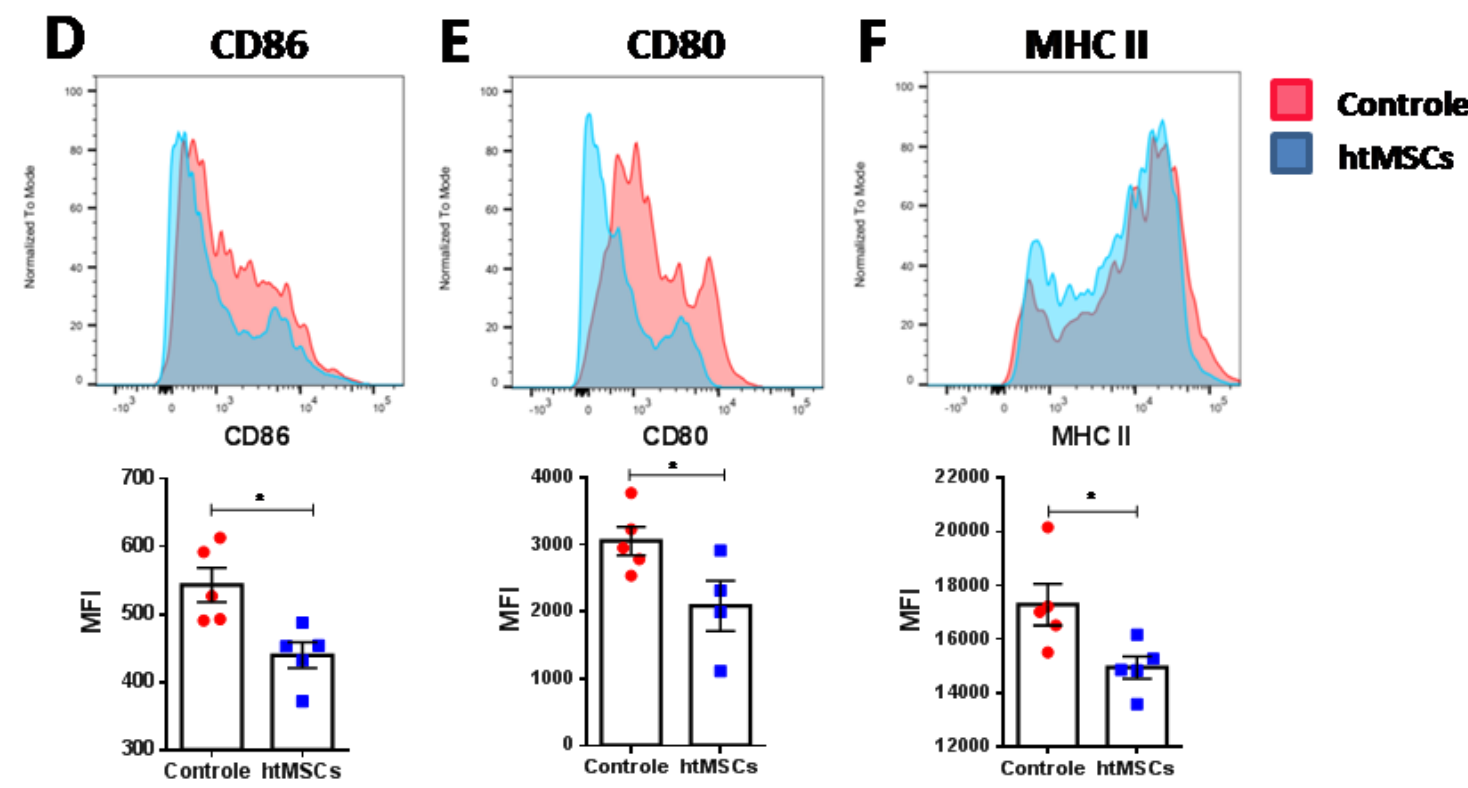

htMscs 
expressão de CD4 e CD8.

A Figura 13 mostra um pequeno aumento na frequência de linfócitos $T$ $\mathrm{CD}^{+}$no baço dos animais tratados com $h t M S C s$ (Fig. $13 \mathrm{~B}$ ), enquanto não ouve alteração na frequência ou número absoluto (Fig. $13 \mathrm{C}, \mathrm{D}$ ) de linfócitos $\mathrm{T}$ $\mathrm{CD}^{+}$. Nos linfonodos, por outro lado, observamos uma redução do número absoluto e da frequência de linfócitos $\mathrm{T} \mathrm{CD}^{+}$(Fig. $13 \mathrm{E}$, F) e T CD8 ${ }^{+}$(Fig $13 \mathrm{G}$, H) no grupo tratado.

Sendo linfócitos Th1 e Th17 as principais subpopulações da patologia da $\mathrm{EAE}$, as quais são caracterizadas pela produção das citocinas IFN-y e IL-17, respectivamente, o próximo passo foi analisar o perfi de citocinas dos grupos tratado e não tratado. Para isso, os esplenócitos totais e células totais do linfonodo extraídos no $7^{\circ}$ dia pós-imunização foram re-estimuladas ou não in vitro com $\mathrm{MOG}_{35-55}$ e a-CD3. Após 72 horas de cultivo o sobrenadante foi coletado para análise do perfil de citocinas por citometria de acordo com materiais e métodos (3.10.4).

No baço, apesar de conseguir modular a produção da citocina IFN- $\gamma$ (Fig. 14 A), não houve modulação das citocinas inflamatórias IL-17, IL-6 e TNF (Fig. $14 \mathrm{C}, \mathrm{G}, \mathrm{I}$ ). No linfonodo, o tratamento com as htMSCs, além de modular o perfil de linfócitos T CD4+ conforme visto no resultado anterior (Fig. $13 \mathrm{E}, \mathrm{F}$ ), foi capaz de modular a produção das citocinas IFN-y e IL-17 (Fig. 14 B, D), características das subpopulações dos linfócitos Th1 e Th17, respectivamente, porém, não observamos modulação nas citocinas inflamatórias IL-6 e TNF (Fig. $14 \mathrm{H}, \mathrm{J})$. Por fim, surpreendentemente, o re-estímulo com MOG $35-55$ elevou os níveis de secreção da citocina anti-inflamatória IL-10 nos animais tratados em relação aos controles no baço (Fig. 14 E) e linfonodo (Fig. 14 F).

Dessa forma, podemos concluir que o tratamento com htMSCs é capaz de reduzir linfócitos Th1 e Th17 nos linfonodos de animais tratados e causar o aumento da produção da citocina anti-inflamatória IL-10 no baço e linfonodo dos animais tratados em relação ao grupo controle, porém, não foi o suficiente 
Figura 13 - A população de linfócitos $T \mathrm{CD}^{+}$e $\mathrm{T} \mathrm{CD8}{ }^{+}$é reduzida nos linfonodos de animais tratados com htMSCs nos estágios iniciais da EAE. Células do baço e linfonodos inguinais e periaórticos foram obtidas de animais com EAE tratados ou não com $h t M S C s$ no 70 dia pós-imunização $(\mathrm{n}=5$ por grupo) e foram e re-estimuladas in vitro com $\mathrm{MOG}_{35-55}(1 \mu \mathrm{g} / \mathrm{mL})$ por $12 \mathrm{~h}$ e PMA $(50 \mathrm{ng} / \mathrm{mL})+$ lonomicina $(1 \mu \mathrm{g} / \mathrm{mL}) 4 \mathrm{~h}$. As células foram submetidas a análise por citometria de fluxo das moléculas de superfície celular (A e B, E e F) $\mathrm{CD}^{+}$e (C e D, G e H) $\mathrm{CD}^{+}$. Dados representativos de dois experimentos independentes. Análise Estatística Two way ANOVA, ${ }^{*} p<0,05$; ${ }^{* *} p<0,01 ;{ }^{* * *}$ $p<0,001 e^{* * * *} p<0,0001$ em relação ao controle.

\section{Baço}

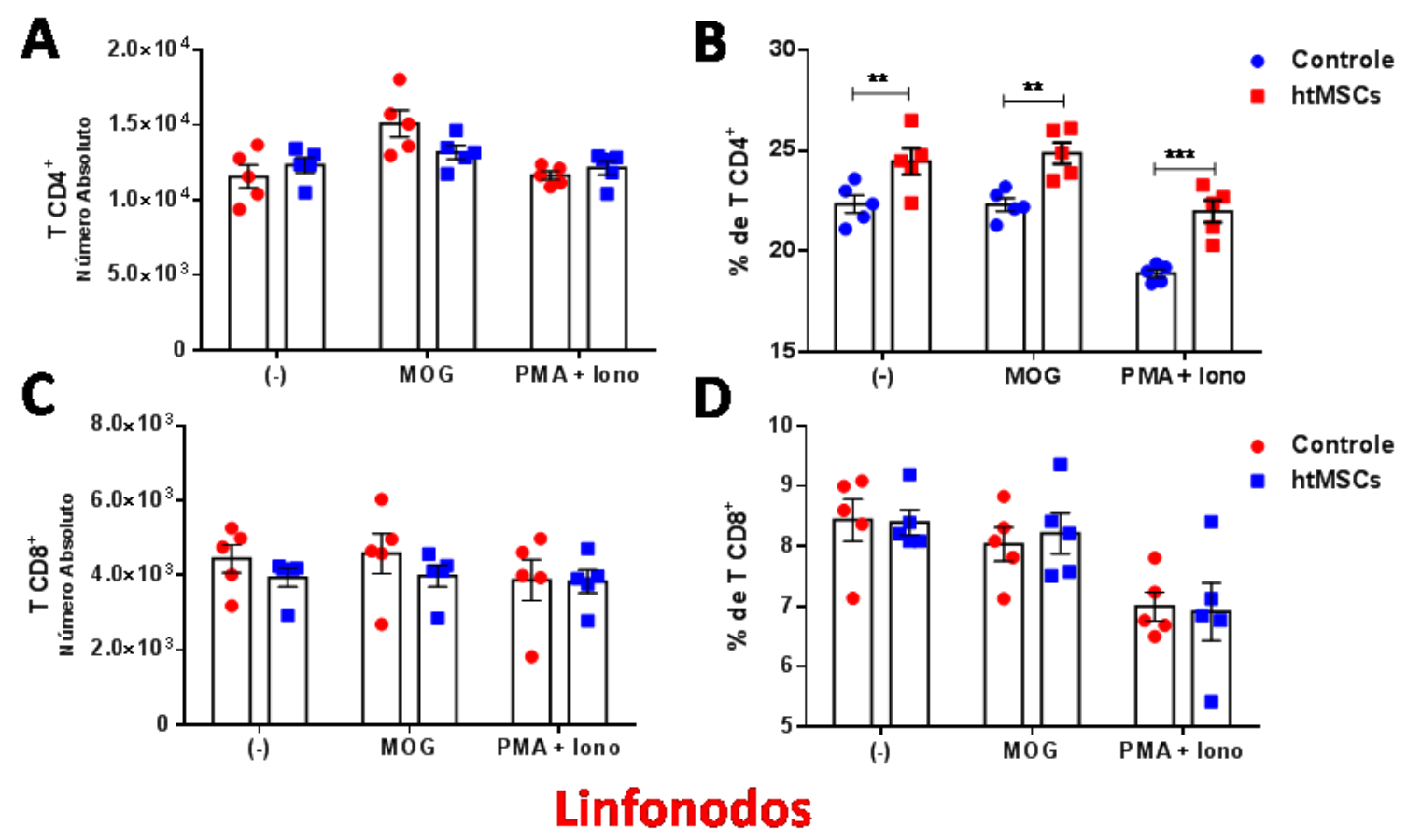

E
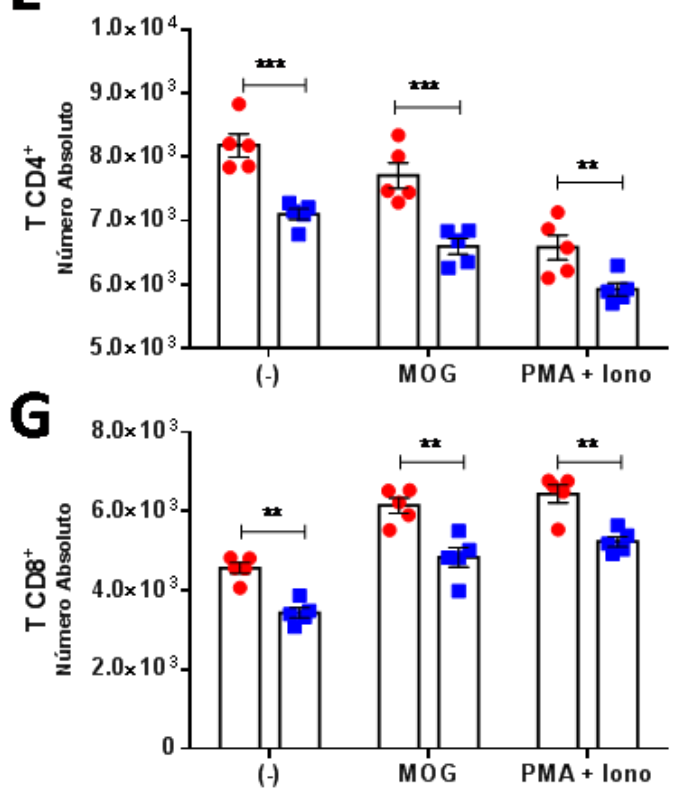

F

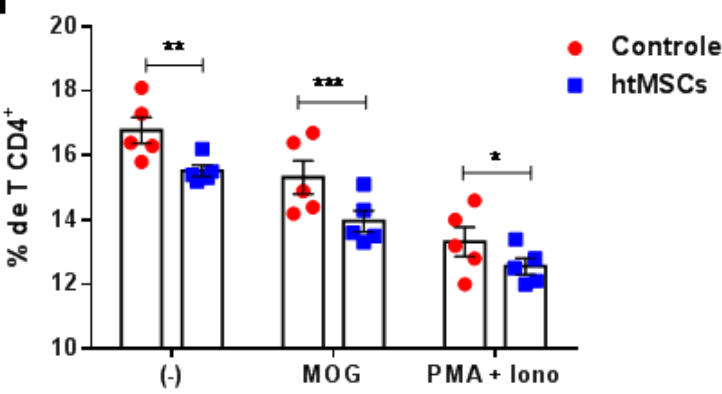

H

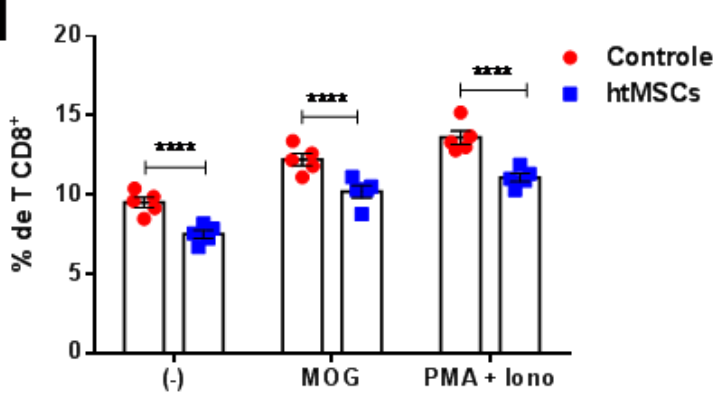


Figura 14 - Perfil de citocinas do baço e linfonodos de animais tratados com htMSCs 7 dias pós-imunização e após re-estimulação in vitro com MOG. Células do baço e linfonodos inguinais e periaórticos foram obtidas de animais com EAE tratados ou não com $h t M S C s$ no 70 dia pós-imunização $(\mathrm{n}=5$ por grupo) e foram obtidos, processados e re-estimulados in vitro com $\mathrm{MOG}_{35}$ $55(1 \mu \mathrm{g} / \mathrm{mL})$ e $\alpha$-CD3 $(1 \mu \mathrm{g} / \mathrm{mL})$; Após 72 horas o sobrenadante foi coletado para análise do perfil de citocinas através da técnica de CBA. Dados representativos de dois experimentos independentes. Análise Estatística Two way ANOVA, * $p<0,05 ;{ }^{* *} p<0,01 ;{ }^{* * *} p<0,001 e^{* * *} p<0,0001$ em relação ao controle.

Baço

A

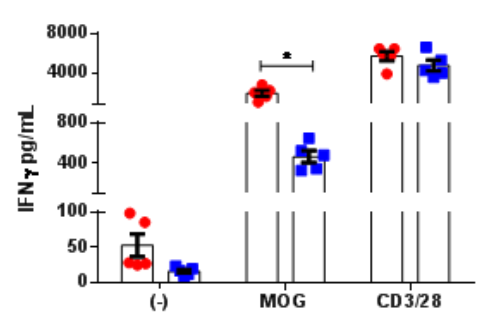

C

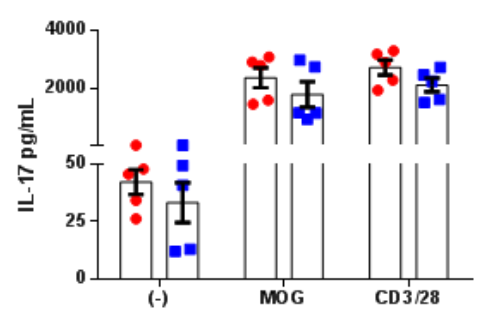

E

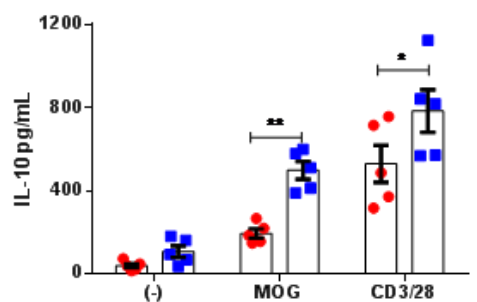

G

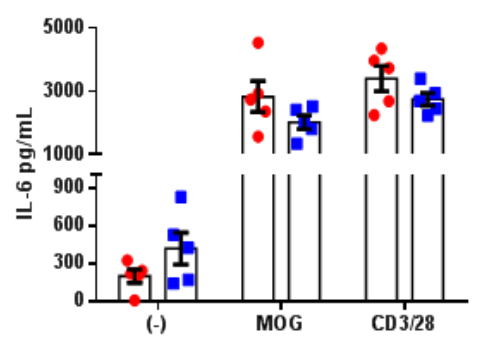

I

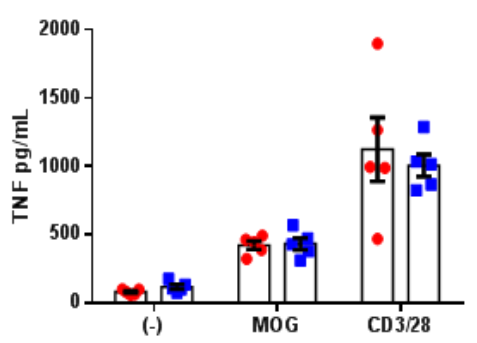

Linfonodos

B

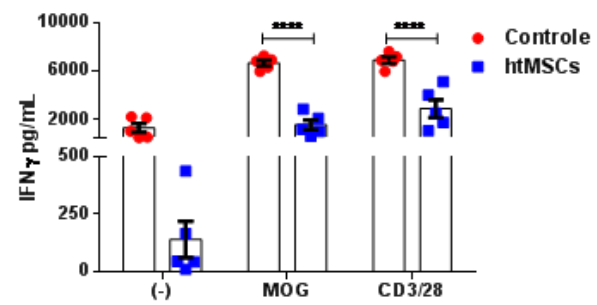

D

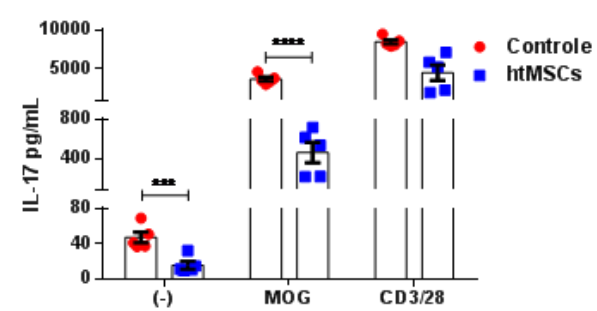

F

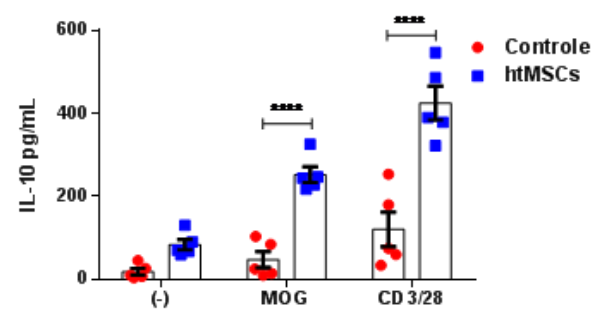

H

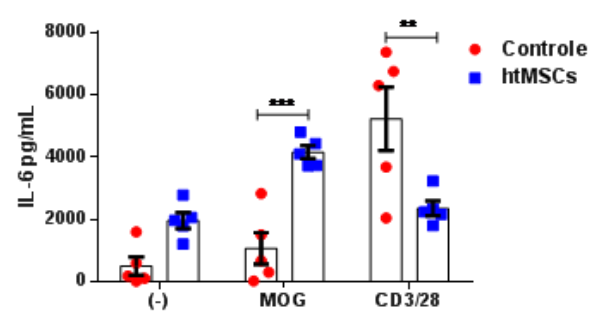

J

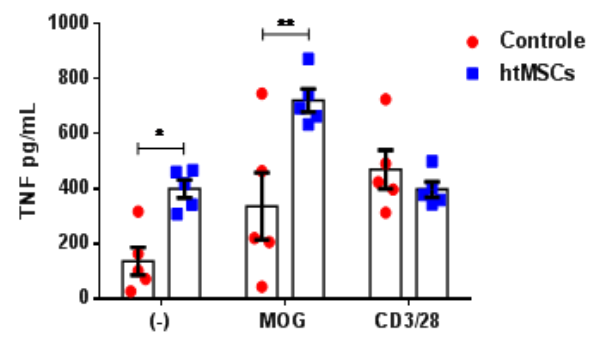


para reduzir a inflamação na periferia, uma vez que não houve diferença nos níveis das citocinas IL-6 e TNF- $\alpha$.

4.4 Avaliação da Imunomodulação das htMSCs durante o pico da EAE na periferia

4.4.1 Perfil de macrófagos e células dendríticas no baço durante o pico da EAE na periferia

Uma vez que o tratamento com duas doses de $h t M S C s$ foi mais efetivo em diminuir os sintomas clínicos nos animais (Fig. 9 A, B), continuamos com essa estratégia para os experimentos seguintes. Agora com foco na fase efetora da doença, C57BL/6 imunizados com $\mathrm{MOG}_{35-55}$ receberam uma dose de htMSCs no dia da imunização (dia 0), uma segunda dose no dia 10 pósimunização e foram acompanhados diariamente até o dia 16. Observamos que o tratamento reduziu significativamente o score dos animais tratados em comparação ao grupo controle e reduziu a progressão da doença in vivo (Fig. $15 \mathrm{~A}, \mathrm{~B})$.

No pico da doença, continuamos a observar diferença no tamanho (Fig. C) e massa (Fig. D) dos baços dos animais tratados e não tratados. Quanto ao perfil celular, apesar de observarmos aumento do número total de células no grupo tratado (Fig. $15 \mathrm{E}$ ), não houve diferença no número total e frequência de células dendríticas (Fig. $15 \mathrm{~F}, \mathrm{G}$ ) e macrófagos (Fig. H, I). Com o objetivo de avaliar se o tratamento continuaria a modular a apresentação de antígenos e ativação das células dendríticas durante a fase efetora da doença, analisamos novamente a expressão das moléculas co-estimuladoras CD86, CD80 e MHC II, das quais, somente as moléculas CD86 (Fig. 16 A) e CD80 (Fig. 16 B) foram moduladas de modo significativo pelo tratamento com htMSCs. Não observamos modulação significativa nos macrófagos do baço.

Dessa forma, concluímos que as htMSCs conseguem modular a ativação de células dendríticas no baço de animais tratados durante o pico da EAE. 
Figura 15 - 0 tratamento com htMSCs reduz a progressão da EAE in vivo, mas não modula o perfil de células dendríticas e macrófagos no baço de animais com EAE 16 dias pós-imunização. Camundongos C57BL/6 que

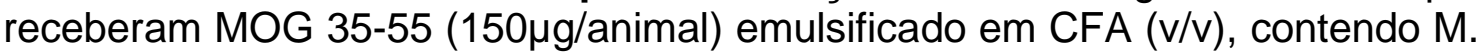

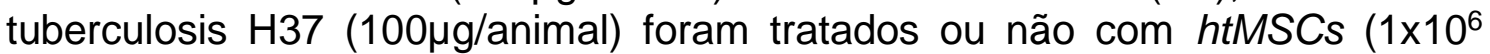
células/animal) via intra-peritoneal no dia 0 e dia 10. (A) Os animais $(n=7$ por grupo) foram analisados em relação ao score clínico da doença diariamente até o dia 16. (B) Mostra o valor da área sob a curva do grupo tratado e não tratado. (C) Comparação do tamanho e (D) massa do baço entre o grupo controle e tratado. Células do baço foram obtidas de animais com EAE tratados ou não com $h t M S C s$ no 160 dia pós-imunização ( $\mathrm{n}=5$ por grupo) e foram submetidas a análise por citometria de fluxo quanto $(E)$ número de células totais, frequência e número absoluto das populações de células dendríticas $\left(\mathrm{CD} 11 \mathrm{c}^{+} \mathrm{MHC} \mathrm{II}^{+}\right)(\mathbf{F}$, G) e macrófagos $\left(F 4 / 80^{+} \mathrm{CD} 11 \mathrm{~b}^{+}\right)(\mathbf{H}, \mathbf{I})$. Dados representativos de três experimentos independentes. Análise Estatística $T$ test, ${ }^{\star} p<0,05 ;{ }^{* * *} p<0,001$ $e^{* * * \star} p<0,0001$ em relação ao controle.
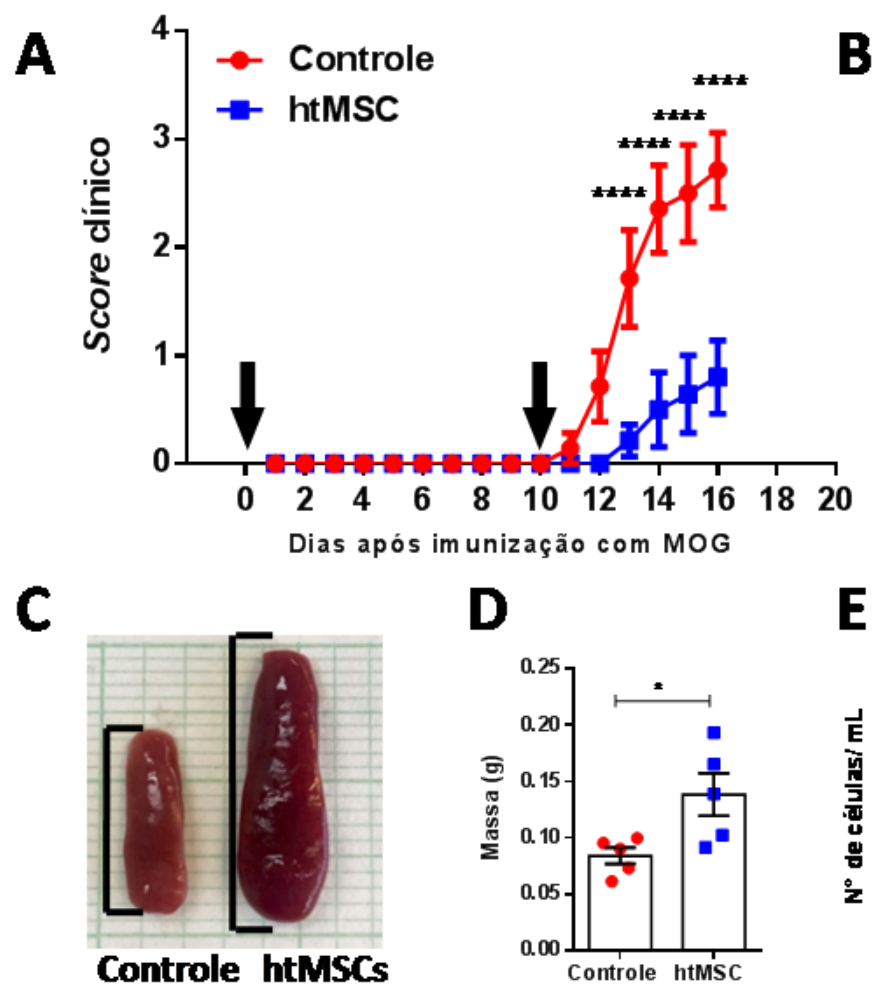

B
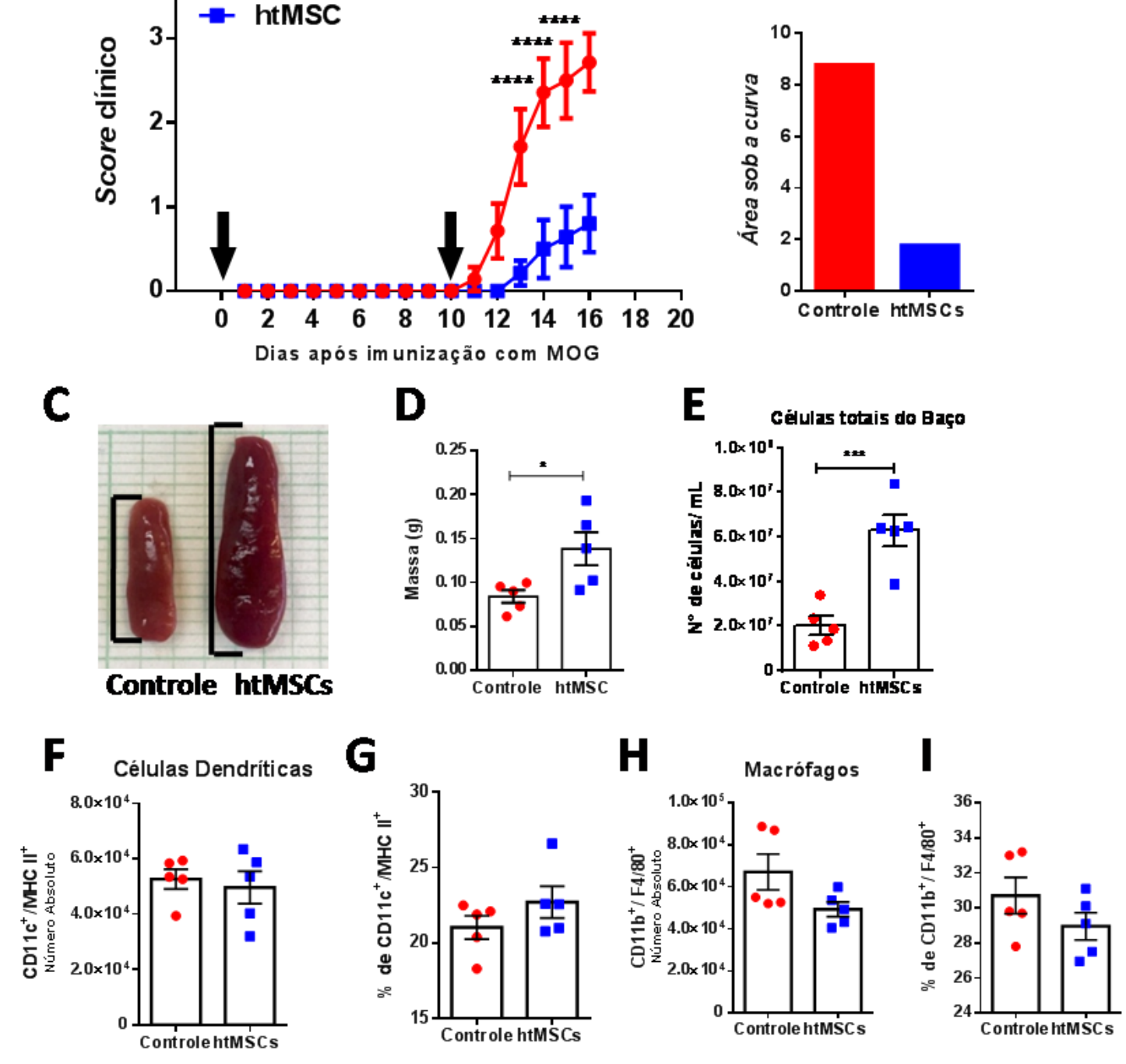
Figura 16 - Expressão das moléculas CD86, CD80 é reduzida em células dendríticas (CD11C+MHC $\mathrm{II}^{+}$) durante 0 pico da doença nos baços de animais com EAE tratados com htMSCs. Células do baço foram obtidas de animais com EAE tratados ou não com $h t M S C s$ no dia da imunuzação e no $16^{0}$ dia pós-imunização ( $\mathrm{n}=5$ por grupo) e foram submetidas a análise por citometria de fluxo da expressão das moléculas de superfície celular (A, D) CD86, (B, E) CD80 e (C, F) MHC II na população de células dendríticas e macrófagos. Dados representativos de três experimentos independentes. Análise estatítica $T$ test ${ }^{*} \mathrm{p}<0,05$; ${ }^{* *} \mathrm{p}<0,01 ;{ }^{* *} \mathrm{p}<0,001$ em relação ao controle.

\section{Dendríticas Baço}
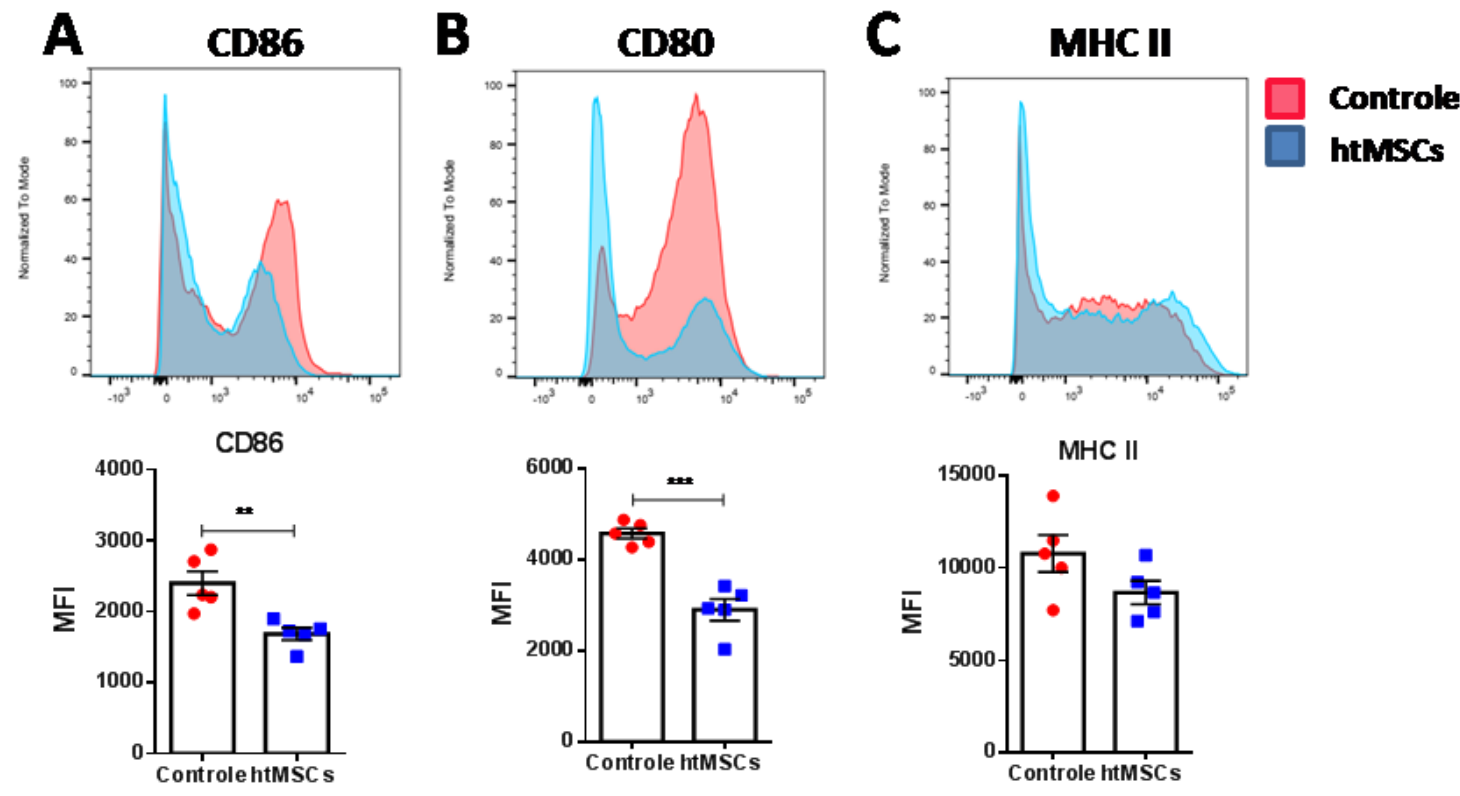

Macrófagos Baço
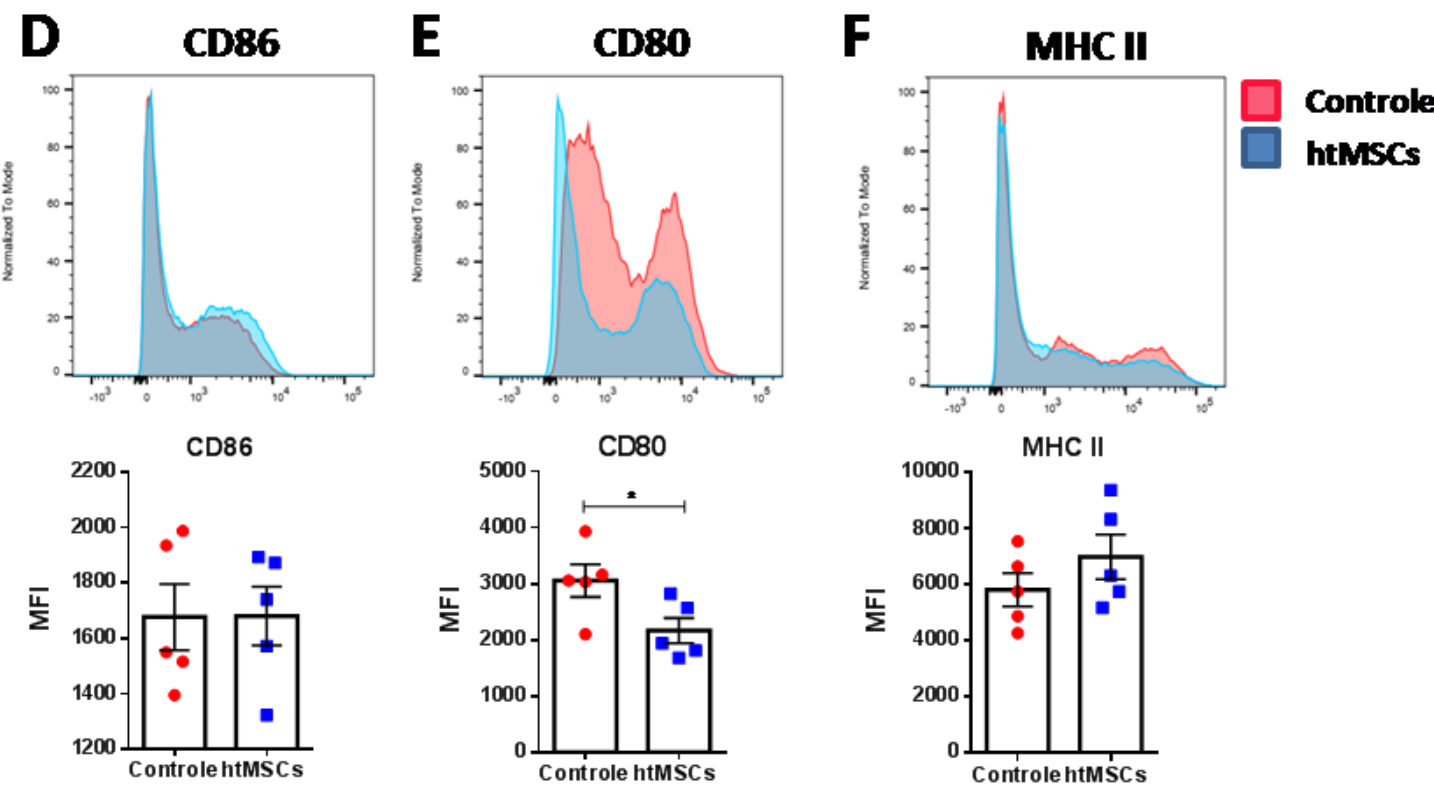
4.4.2 htMSCs não conseguem modular a população de linfócitos $T C D 4^{+}$no baço de animais durante o pico da EAE na periferia.

Com o objetivo de analisar novamente as populações de linfócitos $T$ $\mathrm{CD}^{+}{ }^{+}$e TCD8 ${ }^{+}$no baço dos animais tratados com htMSCs, agora no pico da doença, os esplenócitos totais extraídos no 16 dia pós-imunização, foram reestimulados ou não in vitro com MOG $35-55$ conforme material e métodos (3.10.3) e analisados por citometria de fluxo em relação a expressão de CD4 e CD8. Observamos mudanças apenas nas frequências de linfócitos T CD4+ (Fig. 17 B) e T CD8+ (Fig. 17 D).

Analisamos também as populações de linfócitos Th1 (T CD4+IFN- $\left.\gamma^{+}\right)$e Th17 ( $\mathrm{T} \mathrm{CD4} 4^{+} \mathrm{IL}-17^{+}$) no baço, porém, não houve diferença da frequência ou número absoluto dos mesmos (Fig. 17 E,F, G, H) entre os grupos tratado e controle. Esses dados são corroborados pela análise do perfil de citocinas desses linfócitos, uma vez que a segunda dose de htMSCs não conseguiu modular a produção de INF-y (Fig 18 A) e IL-17 (Fig 18 B). Também não houve modulação das citocinas IL-6 (Fig. 18 D) e TNF- $\alpha$ (Fig. 18 E). Apenas a citocina IL-10 teve um aumento de produção frente ao tratamento com htMSCs, conforme observado no início do estabelecimento da EAE (Fig. 14 E).

Coletivamente, os dados demonstram que, no pico da doença, o tratamento com as duas doses de htMSCs, apesar de aumentar a inibição da progressão da EAE in vivo, não é capaz de inibir ou reduzir a secreção das citocinas dos perfis patogênicos da doença, Th1 e Th17, no baço de animais tratados em relação ao controle. 
Figura 17 - A população de linfócitos T CD4+ e T CD8 ${ }^{+}$não é modulada no baço de animais tratados com htMSCs no pico da EAE. Células do baço foram obtidas de animais com EAE tratados ou não com htMSCs no dia da imunização e no 16음 dia pós-imunização ( $n=5$ por grupo), foram re-estimuladas in vitro com MOG $35-55(1 \mu \mathrm{g} / \mathrm{mL})$ por $12 \mathrm{~h}$ e PMA $(50 \mathrm{ng} / \mathrm{mL})$ + lonomicina (1 $\mu \mathrm{g} / \mathrm{mL}$ ) $4 \mathrm{~h}$. As células foram submetidas a análise por citometria de fluxo das moléculas de superfície celular (A e B) $\mathrm{CD}_{4+}$, (C e D) $\mathrm{CD}^{+}$e para as

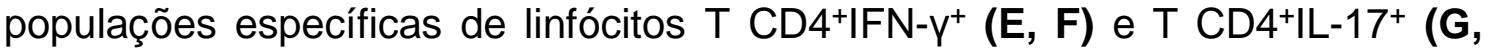
H). Dados representativos de três experimentos independentes. Análise Estatística Two way ANOVA, ${ }^{* *} p<0,01 ;{ }^{* * *} p<0,001$ e ${ }^{* * *} p<0,001$ em relação ao controle.

A

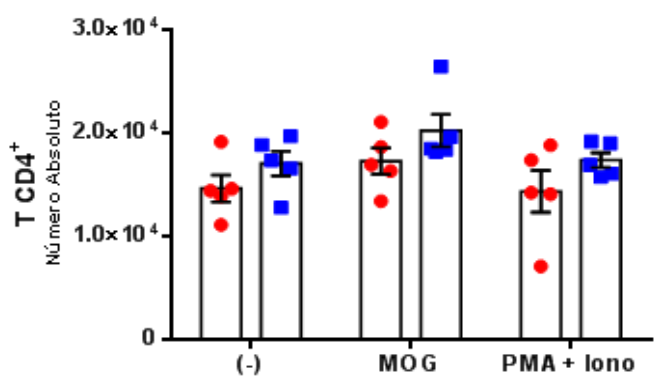

C

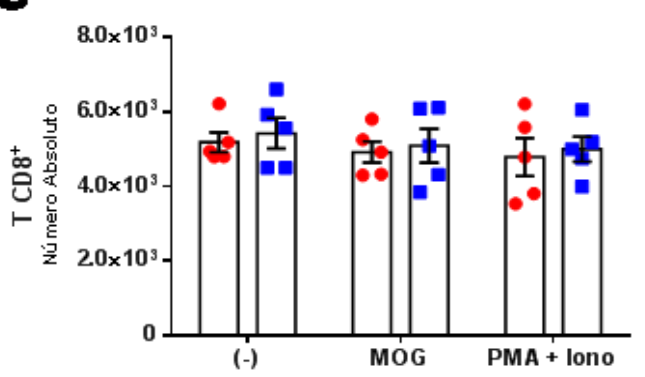

E

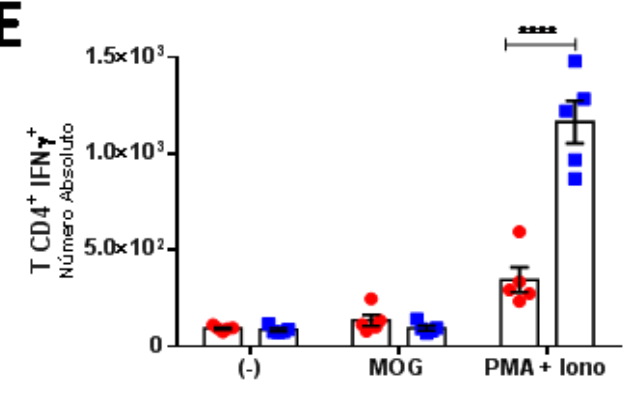

G

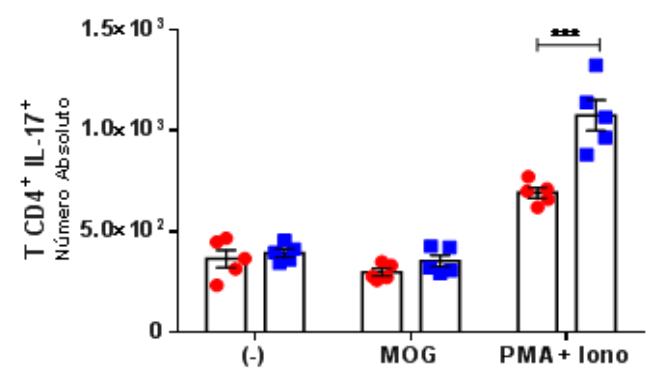

B

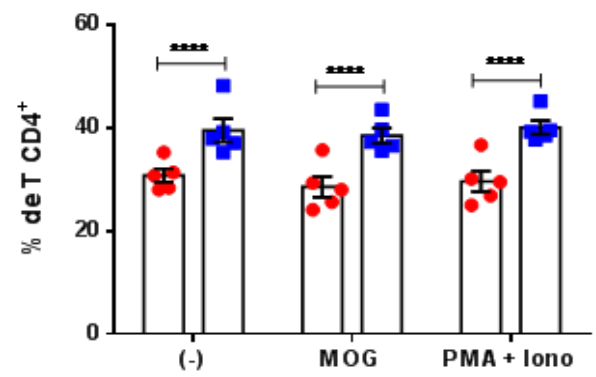

D
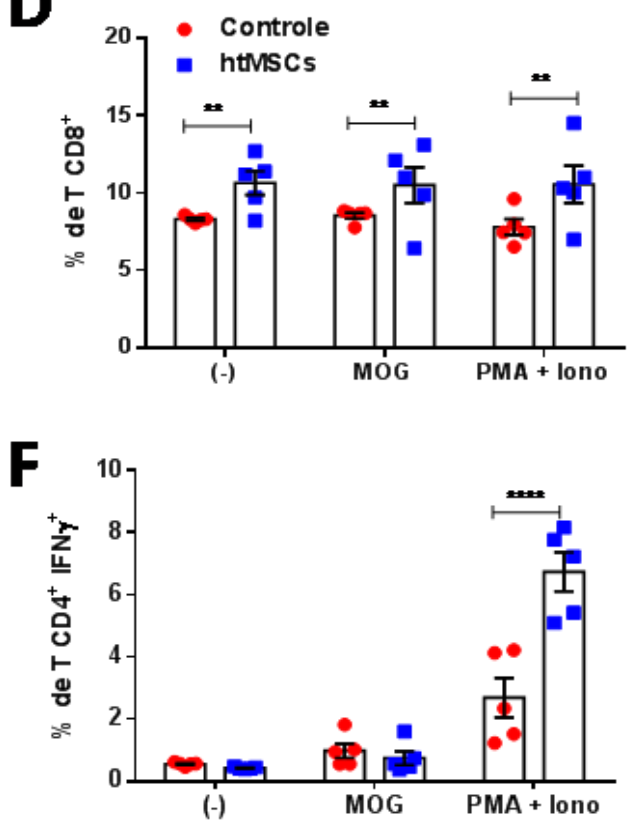

H

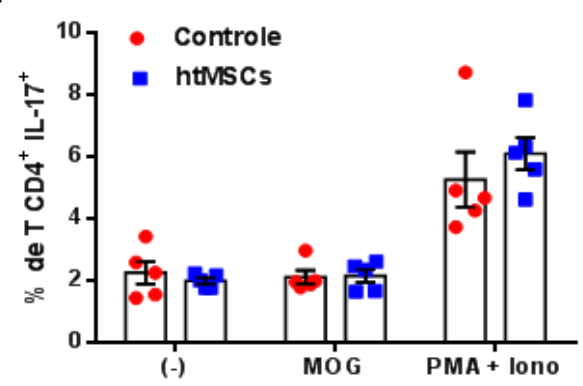


Figura 18 - Perfil de citocinas do baço de animais tratados com htMSCs 16 dias pós-imunização e após re-estimulação in vitro com MOG. Células do baço foram obtidas de animais com EAE tratados ou não com htMSCs no dia da imunização e no $16^{0}$ dia pós-imunização ( $n=5$ por grupo), foram obtidos, processados e re-estimulados in vitro com $\mathrm{MOG}_{35-55}(1 \mu \mathrm{g} / \mathrm{mL})$ e $\alpha$-CD3 (1 $\mu \mathrm{g} / \mathrm{mL}$ ); Após 72 horas o sobrenadante foi coletado para análise do perfil de citocinas através da técnica de $C B A$. Dados representativos de três experimentos independentes. Análise Estatística Two way ANOVA, * $p<0,05$; ** $p<0,01$ em relação ao controle.

A

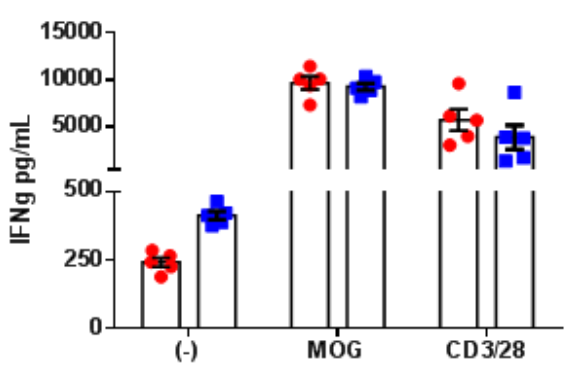

C

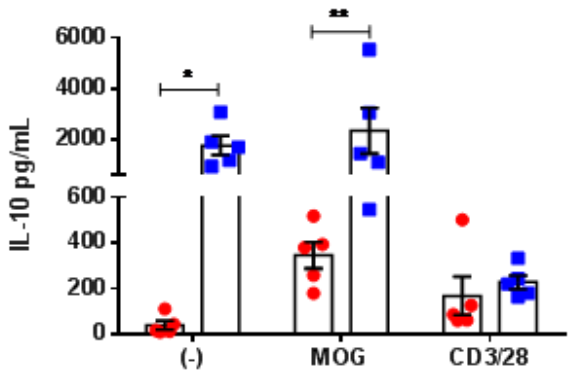

$\mathbf{E}$

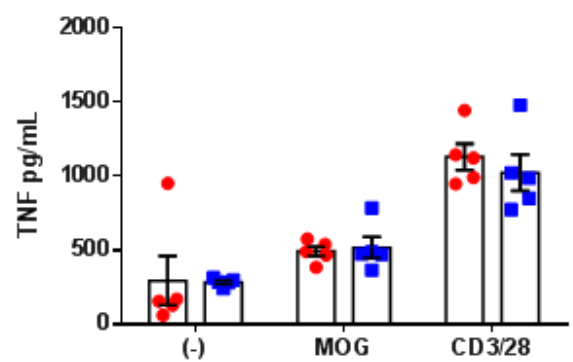

B

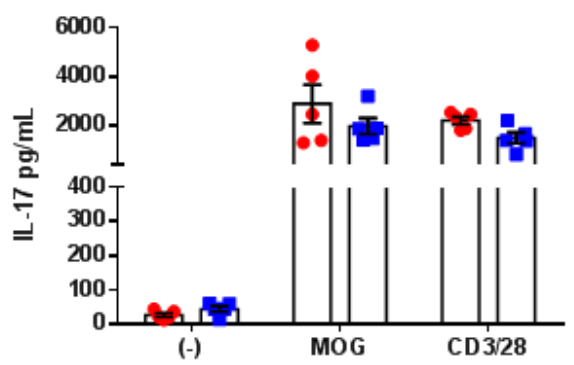

D

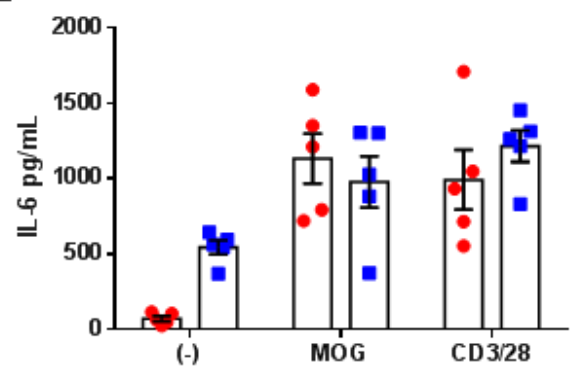


4.5 Imunomodulação das htMSCs no sistema nervoso central durante o pico da EAE

4.5.1 O tratamento com duas doses de htMSCs reduz a neuroinflamação impedindo células inflamatórias de se infiltrarem no cérebro e diminuindo a ativação das células da microglia

Conforme observado nos resultados anteriores, o tratamento com htMSCs reduziu o infiltrado inflamatório e desmielização na medula espinhal dos animais tratados (Fig. $8 \mathrm{C}$ ). Sendo assim, o próximo passo foi analisar as células infiltrantes no sistema nervoso central dos animais, evento que acontece no pico da doença, onde ocorre o ínicio do aparecimento dos sinais clínicos. A figura 19 A mostra que o tratamento com htMSCs reduziu significativamente o número total de células infiltrantes no cérebro dos animais tratados quando comparados ao grupo controle.

Com o objetivo de analisarmos as populações de células presentes no cérebro de animais com EAE no pico da doença, as células mononucleares do SNC foram analisadas por citometria de fluxo em relação às populações de linfócitos infiltrantes $\left(C D 45^{+} \mathrm{CD} 11 \mathrm{~b}^{-}\right)$, macrófagos infiltrantes (CD45 $\left.{ }^{\text {high }} \mathrm{CD} 11 \mathrm{~b}^{+}\right)$ e microglia residente ativada $\left(C D 45^{\left.\text {low } C D 11 b^{+}\right)}\right.$(Fig. 19 B). Os resultados mostram que o tratamento com htMSCs reduziu a frequência e número absoluto de linfócitos (Fig. 19 C, D), macrófagos infiltrantes (Fig. 19 E, F) e células da microglia ativada (Fig. 19 G, H). Ainda, na população de microglia residente, houve diminuição da expressão das moléculas de MHC II (Fig. 19 I) e CD80 (Fig. 19 J). A partir desses dados concluímos que o tratamento com htMSCs ao impedir as células inflamatórias de atingirem o SNC e reduzir a ativação da microglia existente, diminui a neuroinflamação.

4.5.2 O tratamento com htMSCs reduz a infiltração de linfócitos patogênicos Th1 e Th17 no SNC

Uma vez que observamos a redução da neuroinflamação, analisamos especificamente a população de linfócitos infiltrantes. Para isso, as células 
Figura 19 - O tratamento com htMSCs reduz o infiltrado celular no SNC de animais com EAE. Células do sistema nervoso central de camundongos com EAE tratados ou não com duas doses de htMSCs foram obtidas no 160 dia pósimunização e analisadas por citometria de fluxo para identificação do (A) número absoluto de células infiltrantes, (B) das populações de linfócitos $\left(C D 45^{+} C D 11 b^{+}\right)$, macrófagos $\left(C D 45^{\text {high }} C D 11 b^{+}\right)$, microglia $\left(C D 45^{\text {low }} C D 11 b^{+}\right)$, frequência e número absoluto de linfócitos (C, D), macrófagos (E, F) e microglia (G, H). Expressão das moléculas de (I) MHC II e (J) CD80 dentro da população de microglia. Dados representativos de dois experimentos independentes. Análise Estatística $T$ test, ${ }^{*} p<0,05 ;{ }^{* *} p<0,01 ;{ }^{* * *} p<0,001$ e ${ }^{* * *} p<0,0001$ em relação ao controle.
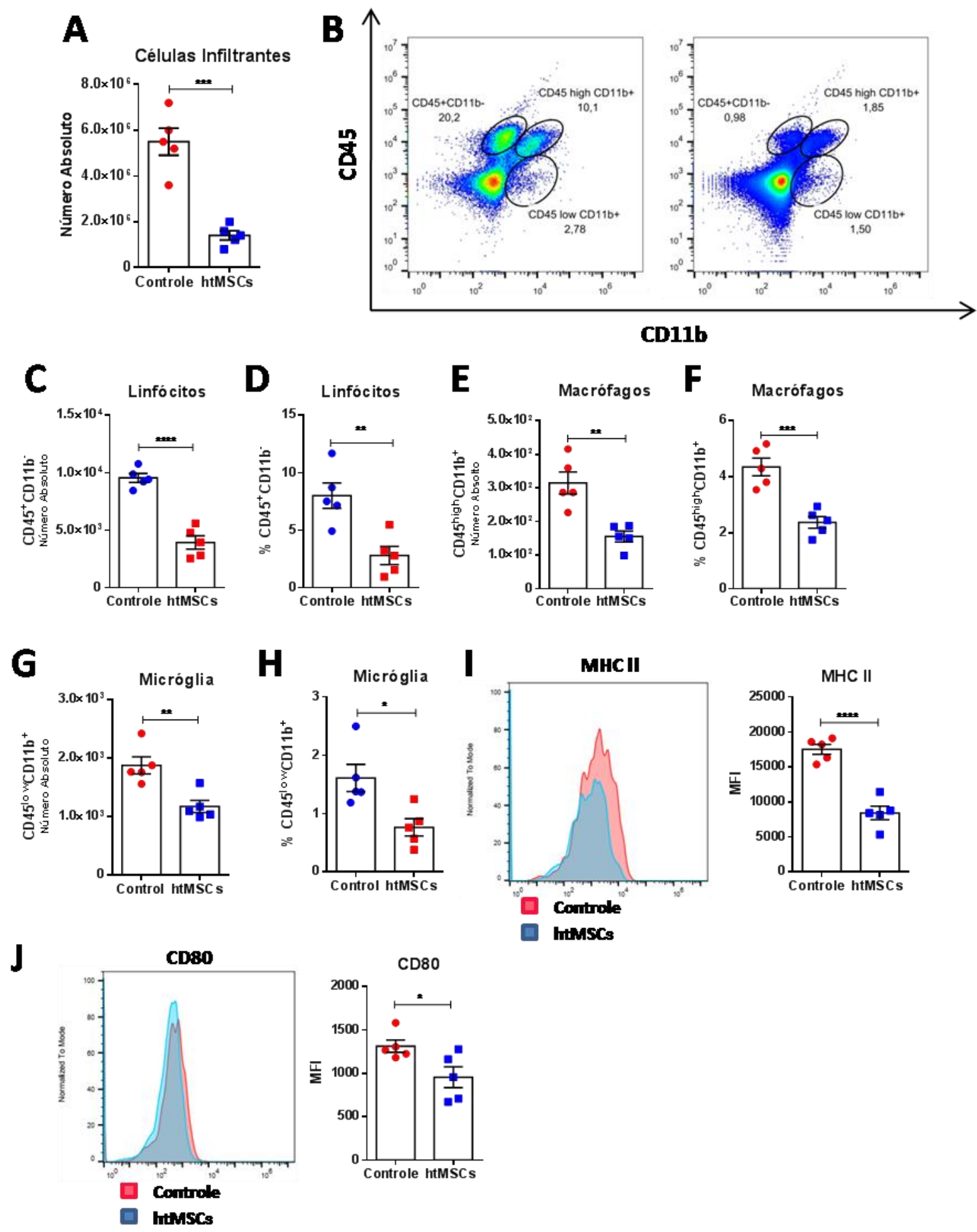
mononucleares do SNC extraídas no pico da doença foram re-estimuladas ou não com $\mathrm{MOG}_{35-55}$ e analisadas em relação a população de linfócitos $\mathrm{T} \mathrm{CD4}^{+} \mathrm{e}$ T CD8+. Dentro da população de células T CD4+, analisamos as subpopulações de linfócitos Th1 produtores de IFN-y (T CD4 ${ }^{+}$IFN- $\left.\mathrm{Y}^{+}\right)$e linfócitos Th17 (T CD4+ $\left.{ }^{+} \mathrm{L}-17^{+}\right)$produtores de IL-17.

O tratamento com htMSCs foi amplamente eficaz em reduzir a freqüência e número absoluto de linfócitos T CD4+ (Fig. 20 A e B) e T CD8 ${ }^{+}$ (Fig. $20 \mathrm{C}$ e D). Mais que isso, reduziu significativamente a expressão, freqüência e número absoluto de células T CD4+IFN- $\gamma^{+}$(Fig. 20 E, F e G). Da mesma forma, os animais tratados apresentaram redução na expressão, freqüência e número absoluto de células T CD4+IL-17+ (Fig. $20 \mathrm{H}, \mathrm{I}$ e J). Coletivamente, esses demonstram que o tratamento com htMSCs reduzem a neuroinflamação impedindo a entrada especificamente de células Th1 e Th17 no SNC de camundongos com EAE.

4.5.3 O tratamento com htMSCs reduz a produção das citocinas IFN-y e IL-17 no cérebro

A última análise do cérebro dos animais com EAE foi o perfil de citocinas das células mononucleadas do SNC extraídas no pico da doença reestimuladas ou não $\mathrm{MOG}_{35-55}$ e $\alpha$-CD3. De fato, o perfil de citocinas corrobora os achados anteriores, uma vez que houve diminuição da produção de IFN-ץ e IL-17 no grupo de animais tratados com htMSCs quando comparados ao grupo controle (Fig. 21 A, B). No cérebro também, assim como no baço e linfonodos, durante a fase inicial da EAE, e no baço durante o pico da EAE, a produção de IL-10 é maior no grupo tratado do que no grupo controle (Fig.21 C), sugerindo que as htMSCs atuem na indução dessa citocina anti-inflamatória.

Não houve alteração na produção das citocina IL-6 e TNF- $\alpha$ entre 0 grupo tratado e controle (Fig. 21 D, E). Esses dados sugerem que essas citocinas pró-inflamatórias não são reguladas pelas htMSCs, entretanto, não interferem no efeito imunomodulador sobre as células encefalitogênicas e não impede a produção de citocinas anti-inflamatórias no cérebro e na periferia. 
Figura 20 - 0 tratamento com $h t M S C s$ reduz o infiltrado de células Th1 e Th17 no SNC de animais com EAE. Células do sistema nervoso central de camundongos com EAE tratados ou não com duas doses de htMSCs foram obtidas no 160 dia pós-imunização e analisadas por citometria de fluxo para identificação da frequência e número absoluto de linfócitos $T \operatorname{CD}^{+}(\mathbf{A}, \mathbf{B})$ e $T$ $\mathrm{CD}^{+}$(C, D); produção das citocinas IFN-Y $(\mathbf{E})$ e IL-17 (H) e frequência e número absoluto das células Th1 (T CD4+ IFN- $\left.\mathbf{Y}^{+}\right)(\mathbf{F}, \mathbf{G})$ e Th17 (T CD4+ IL$\left.17^{+}\right)(\mathbf{I}, \mathbf{J})$. Dados representativos de dois experimentos independentes. Análise Estatística Two way ANOVA test, ${ }^{*} p<0,05 ;{ }^{* \star} p<0,01 ;{ }^{* \star *} p<0,001 e^{* \star * *} p<$ 0,0001 em relação ao controle.

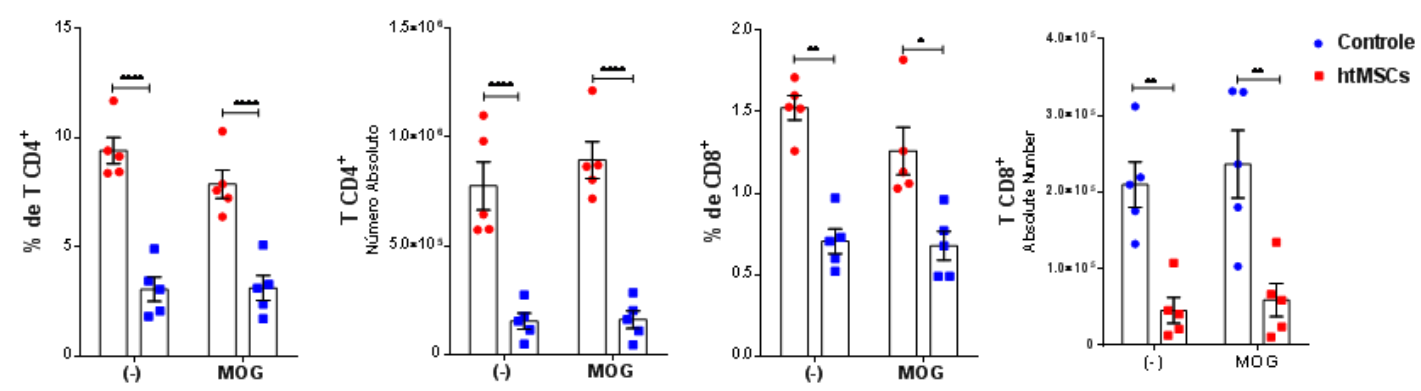

E
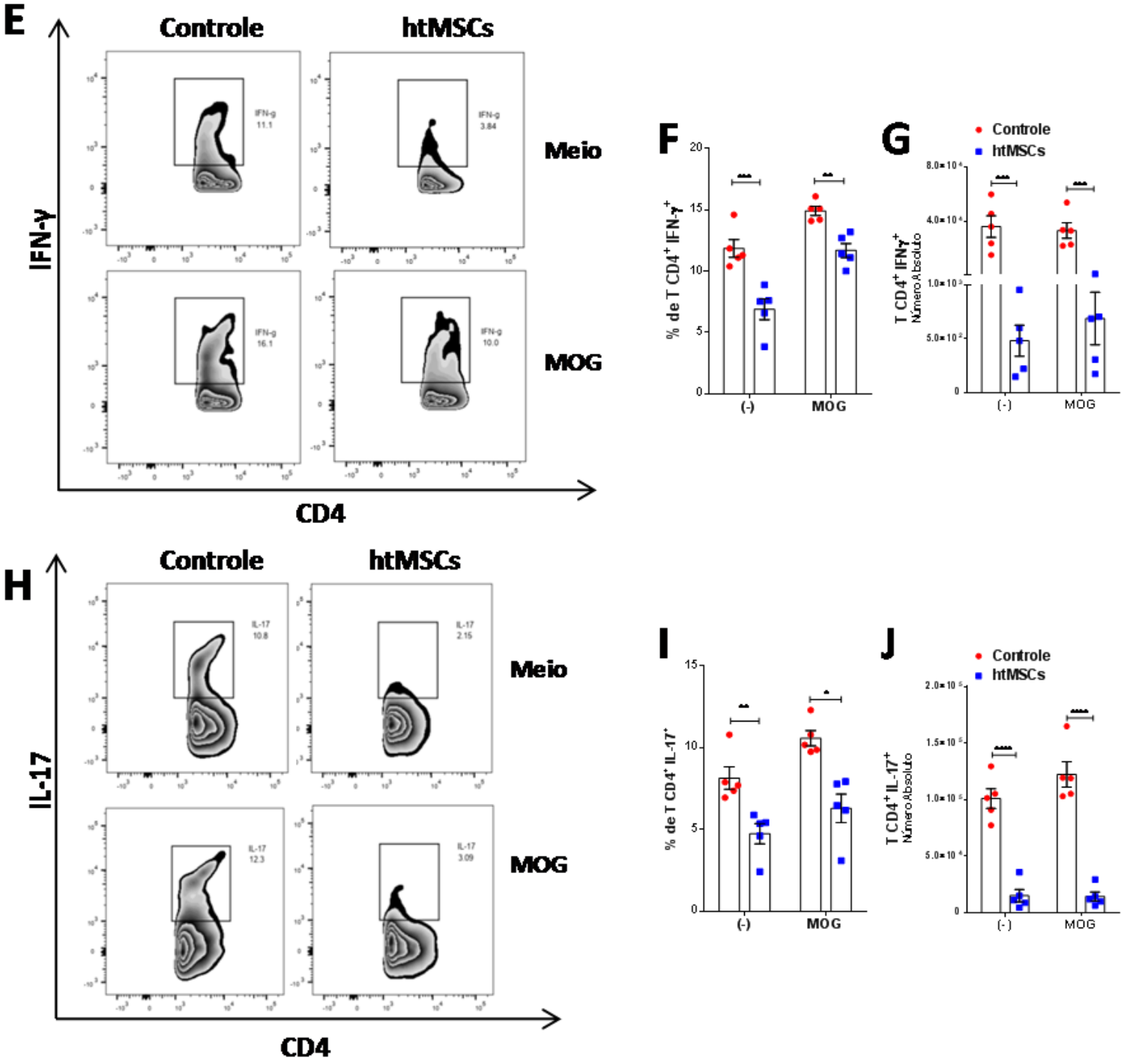
Figura 21 - Perfil de citocinas de células mononucleares do cérebro de animais tratados com htMSCs 16 dias pós-imunização e após reestimulação in vitro com MOG. Células do sistema nervoso central de camundongos com EAE tratados ou não com duas doses de htMSCs foram obtidas no 160 dia pós-imunização ( $n=5$ por grupo) foram obtidos, processados e re-estimulados in vitro com MOG $35-55(1 \mu \mathrm{g} / \mathrm{mL})$ e $\alpha$-CD3 $(1 \mu \mathrm{g} / \mathrm{mL})$; Após 72 horas o sobrenadante foi coletado para análise do perfil de citocinas através da técnica de CBA. Dados representativos de três experimentos independentes. Análise Estatística Two way ANOVA, ${ }^{*} p<0,05 ;{ }^{* \star} p<0,01$ em relação ao controle.

\section{Mononucleares}

A

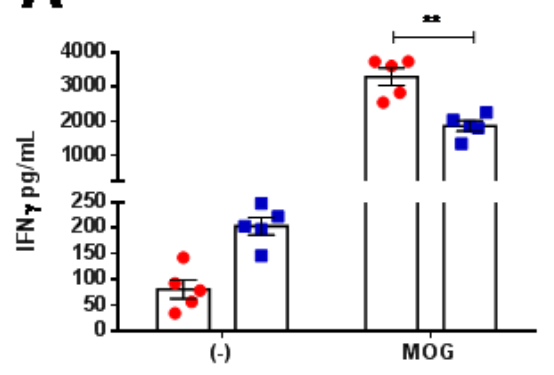

C

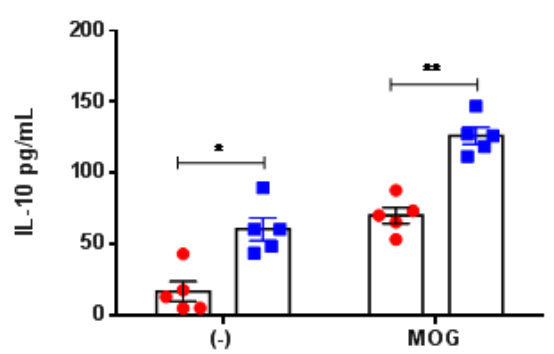

B

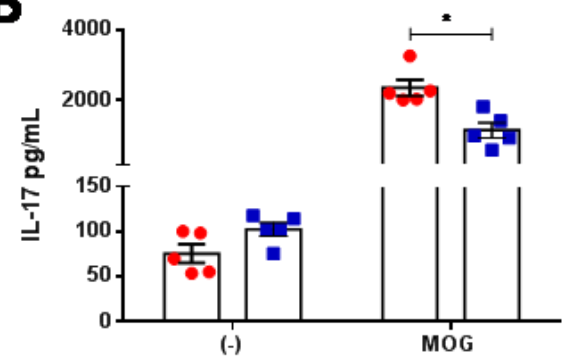

D

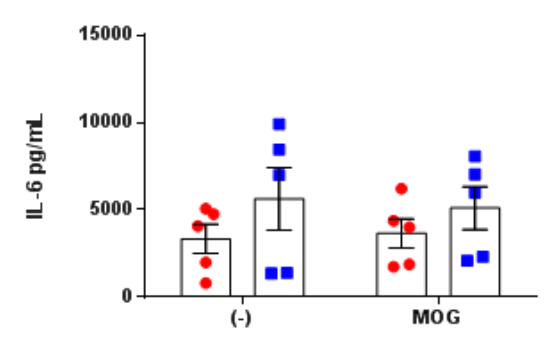

E

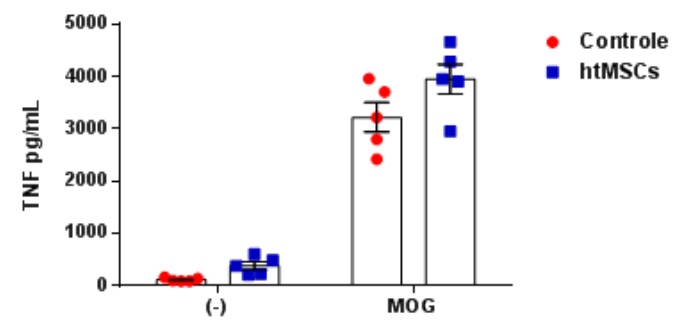


4.6 Avaliação da medula espinhal no pico da doença em animais com EAE tratados com htMSCs

4.6.1 As htMSCs inibem a transcrição dos genes pró-inflamatórios e induzem a transcrição de genes imunomodulatórios na medula espinhal durante o pico da doença

Com o objetivo de avaliar o infiltrado inflamatório, agora no pico da doença, as medulas espinhais obtidas no $16 \underline{0}$ dia pós-imunização foram submetidas a análise histológica por HE. A figura 22 mostra a redução do infiltrado no grupo tratado em comparação ao controle em cortes tranversais (Fig. 22 A) e longitudinais (Fig. 22 B, C).

Verificamos também a capacidade de regulação gênica das htMSCs na medula de animais no pico da doença, de forma semelhante a análise feita no $30^{0}$ dias pós-imunização. As medulas espinhais dos animais tratados ou não foram analisadas quanto a expressão dos mesmos genes analisados previamente. Observamos que no pico da doença, as htMSCs mantém a capacidade de dimimuir a expressão gênica dos genes relacionados às populações de linfócitos T patogênicos Th1 (Fig. 22 D e E) e Th17 (Fig. 22 F) na $E A E$, respectivamente. Nota-se que o tratamento aumentou a expressão do gene Bdnf e IDO (Fig. 22 I, K).

Assim, concluímos que a propriedade imunomoduladora das htMSCs atua na medula espinhal durante o pico da doença e perdura até o $30^{0}$ dia, conferindo proteção aos animais tratados inibindo a progressão da doença.

4.6.2 As htMSCs diminuem a expressão de receptores de quimiocinas e citocinas quimiotáticas na medula espinhal de camundongos EAE

Os dados obtidos até o momento demonstram o papel imunomodulador das htMCSs no modelo da EAE. A fim de avaliarmos por qual mecanismo as células tronco agem, as medulas espinhais de animais com EAE obtidas no 16으 dia pós-imunização foram analisadas por PCR array. Na figura 23, observamos 
que o tratamento com htMSCs aumentou a expressão do gene CCL12 e reduziu a expressão de outros 18 genes, entre eles, o gene da quiocina CCL5 e dos receptores quimiotáticos CCR4, CCR8, CCR6. Esses dados sugerem que as htMSCs podem agir modulando quimiocinas e seus receptores diminuindo assim a entrada de macrófagos e linfócitos no sistema nervoso dos animais tratados. 
Figura 22 - O tratamento com $h t M S C s$ reduz a neuroinflamação e modula a expressão gênica na medula espinhal. Camundongos C57BL/6 que

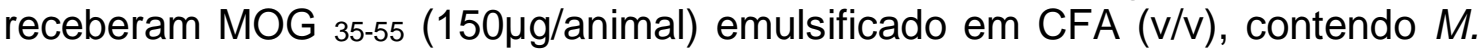

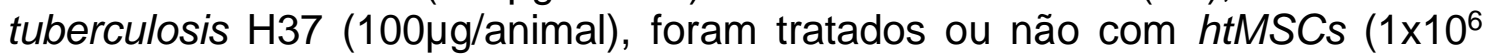
células/animal) via intra-peritoneal no dia 0 e 16 pós-imunização. No dia 16, após eutanásia, a medula espinhal foi obtida e corada com (C) HE para analisar células infiltrantes. O mRNA total da parte distal da medula espinhal foi obtido e analisado por RT-PCR em relação a expressão dos genes (D) Ifng, (E) Tbx21, (F) IIL-17a, (G) Rorc, (H) Foxp3, (I) Bdnb, (J) II27 e (K) Ido. Os dados foram normalizados com o gene da $\beta$-actina e comparados ao grupo Controle. Dados representativos de três experimentos independentes. Análise Estatística $\mathrm{T}$ test, ${ }^{*} \mathrm{p}<0,05 ;{ }^{* *} \mathrm{p}<0,01 ;{ }^{* * *} \mathrm{p}<0,001$

\section{Controle}

A

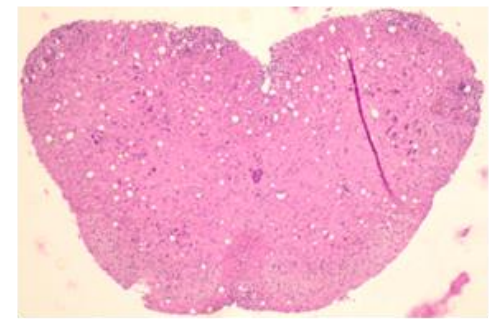

B

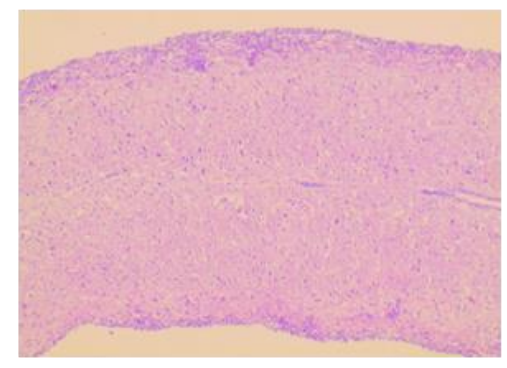

C

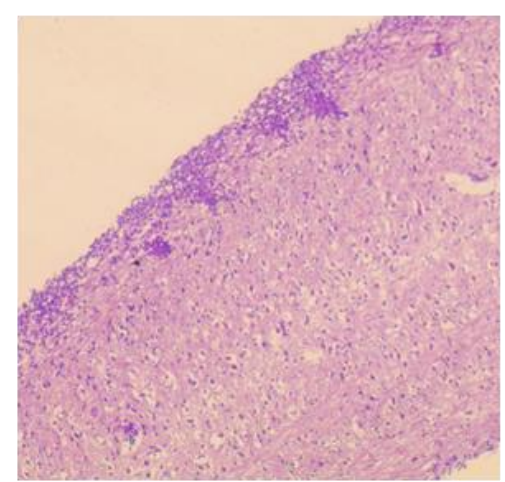

\section{htMSCs}
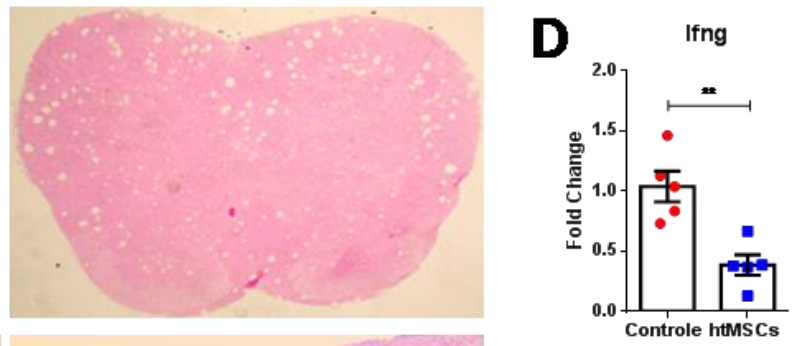

E

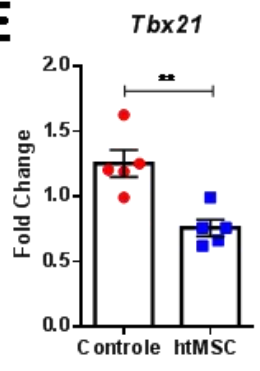

F
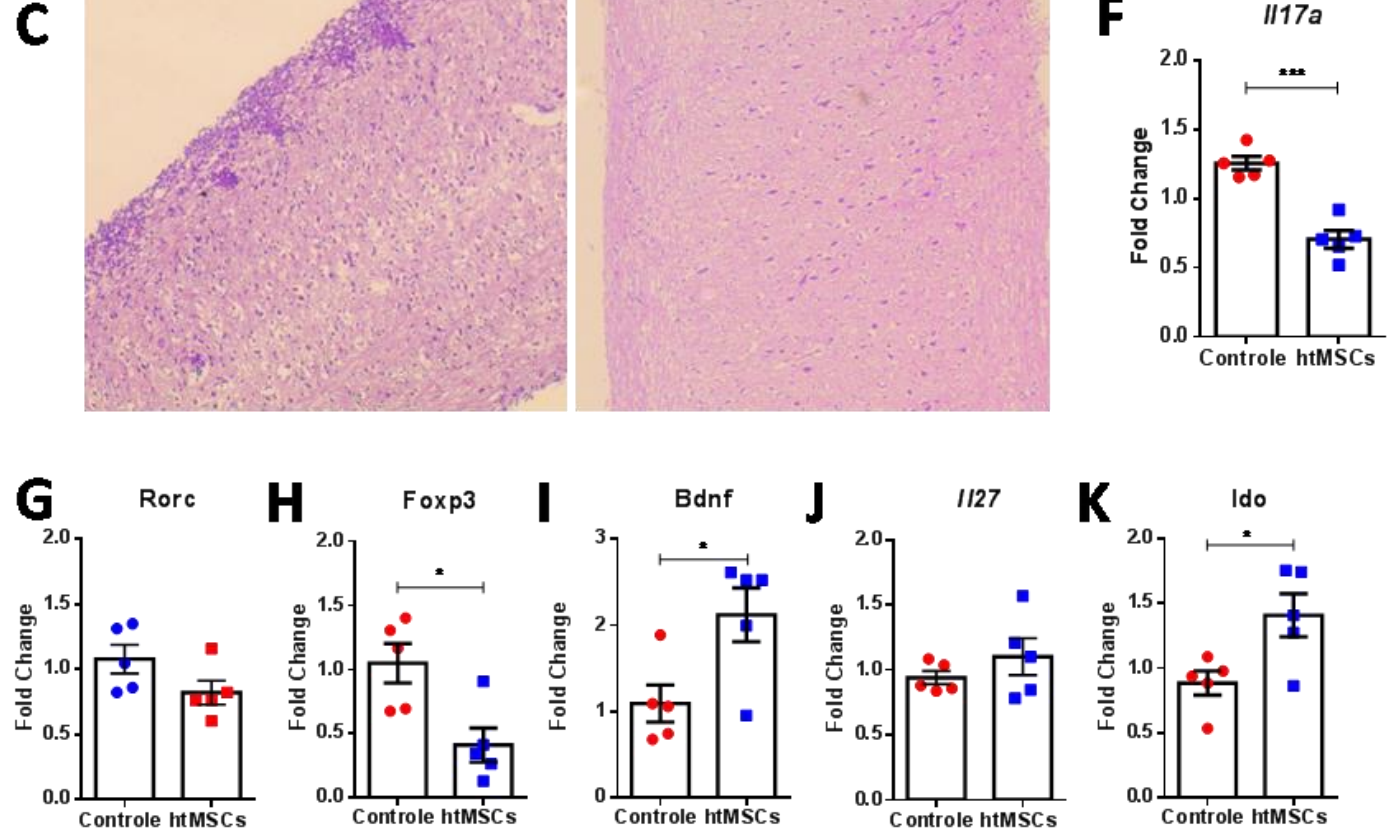
Figura 23 - htMSCs diminuem a expressão de genes de receptores e citocinas quimiotáticas. O mRNA total da parte distal da medula espinhal de animais com EAE tratados ou não com htMSCs nos dias 0 e 16 pósimunização foi obtido e analisado por PCR array. (A) O Gráfico de Dispersão mostra os genes que tiveram sua expressão reduzia em verde e os genes que tiveram maior expressão em relação ao grupo controle em vermelho. (B) Quadro dos genes alterados representados no gráfico de dispersão e seus valores de fold change. (C) Representação gráfica do quadro de genes.

A

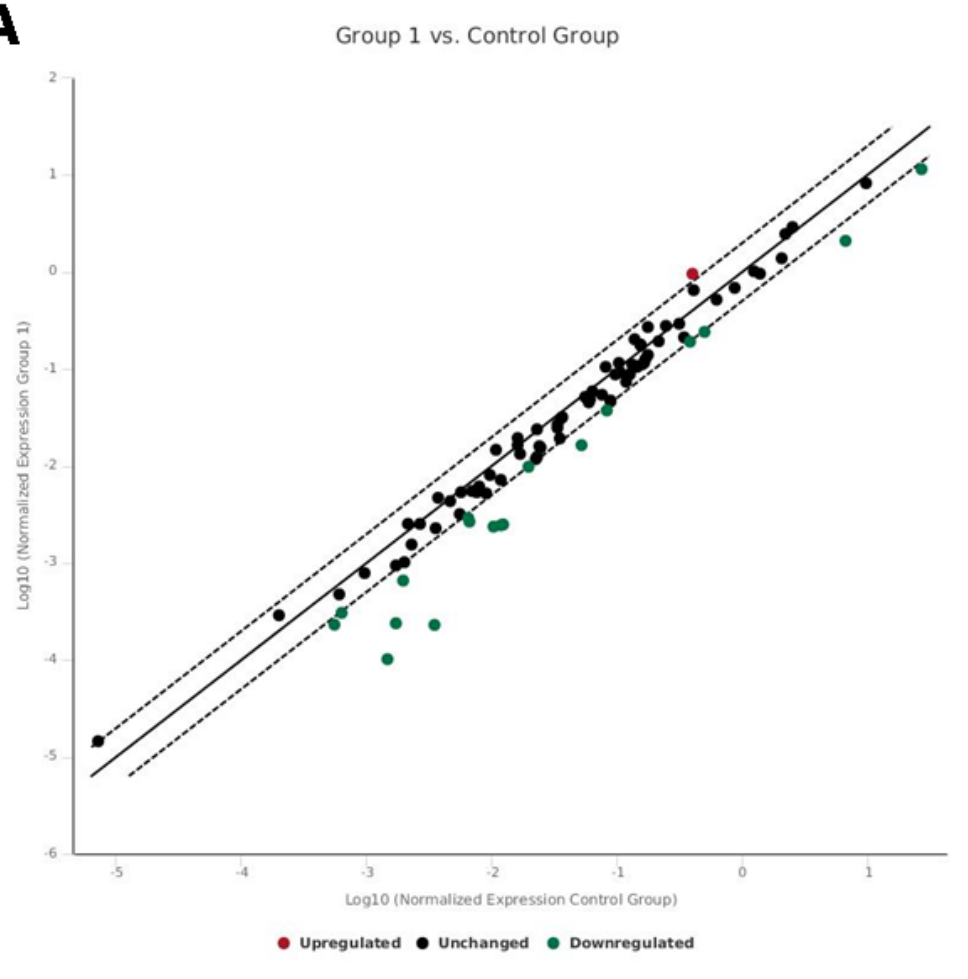

B

\begin{tabular}{|c|c|}
\hline Gene Symbol & $\begin{array}{c}\text { Fold } \\
\text { Regulation }\end{array}$ \\
\hline C3 & $-2,07$ \\
\hline C5ar1 & $-2,24$ \\
\hline CcL5 & $-2,03$ \\
\hline Ccr4 & $-2,49$ \\
\hline Ccr6 & $-4,4$ \\
\hline Ccr8 & $-2,23$ \\
\hline Crp & $-2,42$ \\
\hline Cs12 & $-4,94$ \\
\hline Ina2 & $-15,48$ \\
\hline Ifnb1 & $-7,32$ \\
\hline II10 & $-2,08$ \\
\hline Ly22 & $-3,23$ \\
\hline Mb12 & $-14,47$ \\
\hline Mp0 & $-4,81$ \\
\hline Stat6 & $-3,03$ \\
\hline Tr8 & $-3,22$ \\
\hline Tr9 & $-2,03$ \\
\hline B2m & $-2,33$ \\
\hline Ccl12 & $\mathbf{2 , 3 9}$ \\
\hline
\end{tabular}

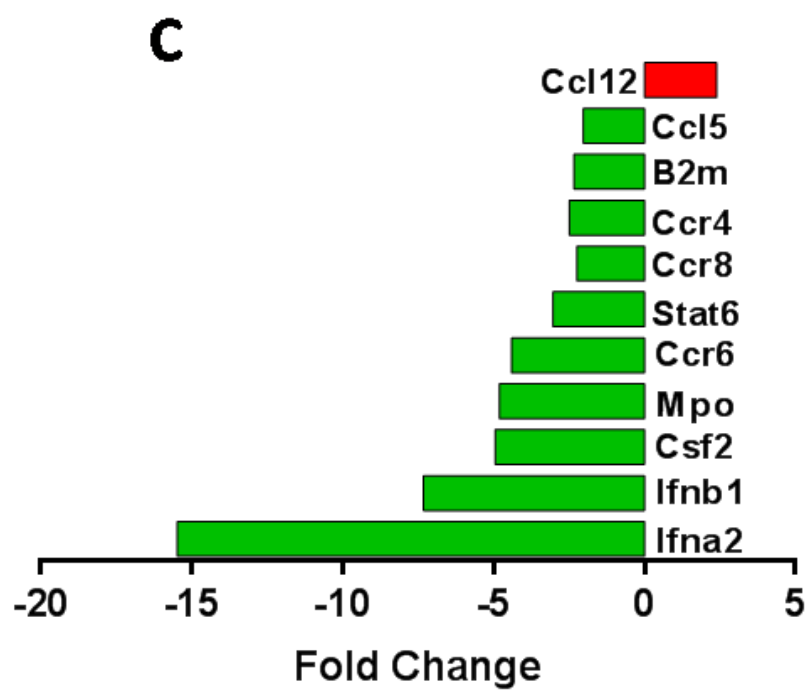




\section{DISCUSSÃo}

Células-tronco estromais adultas são tipicamente definidas como células multipotentes não diferenciadas que possuem a capacidade de auto-renovação e o potencial de se diferenciar em linhagens celulares distintas (Dominici, Le Blanc et al. 2006), além de constituírem um reservatório nos tecidos conjuntivos na maioria dos órgãos e estarem envolvidas na manutenção e reparo. Apesar de serem funcionalmente heterogêneas, as populações de hMSCs isoladas de diferentes tecidos como medula óssea, músculo esquelético, tecido adiposo, polpa dentária, placenta e cordão umbilical (Bobis, Jarocha et al. 2006, Phinney and Prockop 2007, de Mendonca Costa, Bueno et al. 2008, Evangelista, Soncini et al. 2008, Secco, Zucconi et al. 2008, Valtieri and Sorrentino 2008, Warburton, Perin et al. 2008) apresentam um perfil similar de expressão de receptores de superfície.

Em nosso trabalho, utilizamos a célula-tronco estromal derivada de tubas uterinas humanas, a qual apresentou a capacidade de se diferenciar em adipócitos, condrócitos e osteócitos, e demonstrou possuir expressão das moléculas de superfície CD29, CD44, CD73, CD90 e HLA-ABC, receptores característicos de hMSCs. Dessa forma comprovamos que as htMSCs são adequadas para o nosso estudo.

Um dos maiores desafios da medicina é encontrar um tratamento seguro e eficaz para doenças relacionadas ao sistema imunológico. No entanto, devido à baixa eficácia do tratamento disponível e à ocorrência de efeitos adversos graves, muitos grupos estão atualmente procurando alternativas à terapia tradicional. Nesse sentido, o uso de hMSCs representa uma grande promessa para o tratamento de uma variedade de doenças relacionadas ao sistema imunológico devido às suas propriedades imunomoduladoras potentes, porém, as hMSCs não são supressoras por natureza e essa resposta às células imunológicas depende dos sinais inflamatórios do microambiente (Ren, Zhang et al. 2008, Ren, Zhao et al. 2010). 
Nossos dados são corroborados in vivo por hMSCs de origens distintas no tratamento da EAE. hMSCs derivadas da geléia de Wharton foram utilizadas como tratamento em duas doses nos dias 3 e 11 pós-imunização (Torkaman, Ghollasi et al. 2017). hMSCs derivadas de tecido adiposo inoculadas apenas uma dose no início da doença antes do surgimento dos sintomas (Anderson, Gonzalez-Rey et al. 2017). Assim como as htMSCs, essas estratégias preventivas foram efetivas para diminuir a progressão da doença nos animais tratados com htMSCs.

Por outro lado, trabalhos com $h M S C s$ derivadas de medula óssea, polpa dentária e tecido adiposo, foram efetivos mediante o tratamento nos dias 13, 14 e 15 pós imunização, respectivamente (Hou, Ryu et al. 2013, Shalaby, Sabbah et al. 2016, Shimojima, Takeuchi et al. 2016). De forma contraditória, o tratamento aqui demonstrado não foi eficaz quando realizado no dia 10. Dessa forma, concluímos que o as htMSCs não são boa candidatas a uma estratégica terapêutica. Todavia, vale mencionar que estudamos um modelo experimental, a EAE, no qual o estímulo com CFA é bastante robusto e, talvez, muito mais intenso do que o observado em pacientes com EM.

$\mathrm{Na}$ busca do mecanismo responsável por conferir a inibição da progressão da doença, encontramos dados interessantes na medula espinhal dos animais tratados com htMSCs. Em ambas as estratégias de tratamento, dose única ou com a segunda dose 10 dias pós-imunização, ao longo de 30 dias pós imunização e no pico da doença, a expressão de genes relacionados com os linfócitos de perfis Th1 e Th17 estavam diminuídos, porém, o que nos chamou a atenção, foi o fato da expressão dos genes Bdnf, Ido estarem aumentadas nos animais tratados com htMSCs.

O BDNF é um fator neurotrófico envolvido no desenvolvimento e função das células nervosas. Pacientes com EM quando comparado com indivíduos saudáveis, apresentam os níveis de BDNF diminuídos, sugerindo não só a presença de neuro-degeneração como possivelmente baixa capacidade de reparação. Após um surto, no entanto, o BDNF se encontra aumentado no soro, em relação aos níveis basais, provavelmente pelo fato de as células 
inflamatórias infiltrantes, macrófagos e linfócitos produzirem BDNF após a inflamação aguda no SNC (Frota, Rodrigues et al. 2009).

Tafreshi et al. relataram que fatores neurotróficos como BDNF também são expressos constitutivamente por hMSCs derivadas de tecido adiposo, evidenciando o potencial desse tipo de célula-tronco para suporte parácrino em um cenário neurodegenerativo (Tafreshi, Payne et al. 2014). Nossos dados sugerem que as htMCSs, de alguma forma, colaboram para o aumento da expressão do gene BDNF, auxiliando na reparação dos danos causados pela EAE.

Outro mecanismo de ação das hMSCs descrito na literatura é a expressão intracelular de IDO. Sabe-se que, quando exposta a altos níveis de IFN-y, hMSCs produzem IDO, enzima que depleta o triptofano, aminoácido essencial para a proliferação de linfócitos (Krampera, Cosmi et al. 2006). Trabalhos com hMSCs nos modelos da EAE (Donders, Bogie et al. 2018), artrite reumatóide (Luz-Crawford, Torres et al. 2016) e colite ulcerativa relatam esse fenômeno (Duijvestein, Wildenberg et al. 2011). Donders et al. demonstrou que após estimular hMSCs derivadas da geléia de wharton com IFN-y, havia aumento na expressão de IDO e diminuição da proliferação de linfócitos $\mathrm{T}$ na cocultura de células de Wharton e células mononucleadas de sangue periférico em placas transwel ${ }^{\circledR}$. A inibição de IDO usando o 1-metil-Ltriptofano neutralizou a capacidade das células de Wharton de suprimir a proliferação dos linfócitos, comprovando assim o efeito parácrino da IDO nos linfócitos T. Dessa forma, apesar de observarmos um aumento da IDO na medula de animais tratados com htMSCs, sua verdadeira contribuição na supressão da EAE precisa ser mais estudada.

A EAE é caracterizada pela intensa inflamação no SNC, astriogliose, morte neuronal e desmielinização (Rodriguez 2007), resultantes da ativação de linfócitos T CD4 e T CD8 na periferia, sendo as subclasses Th1, produtoras de IFN-y, e Th17, produtoras de IL-17, as mais importantes. As células do sistema nervoso, microglia e astrócitos, expressam em sua superfície receptores para ambas as citocinas (Das Sarma, Ciric et al. 2009) e, quando ativadas, secretam 
citocinas pró-inflamatórias como IL-1, IL-6, IL-23 e IL-17 (Kawanokuchi, Shimizu et al. 2008) levando ao aumento da inflamação e maior recrutamento de monócitos e linfócitos para o SNC.

Em nosso trabalho, os animais tratados com htMSCs apresentaram uma redução significativa do infiltrado inflamatório no cérebro. Esse efeito foi observado tanto no pico da doença como nas análises histopatológicas realizadas 30 dias pós-imunização. Dessa forma, podemos inferir que a severidade da doença está relacionada diretamente ao infiltrado celular no cérebro, conforme descrito na literatura (Peron, Yang et al. 2010). Quando comparamos os infiltrados dos animais tratados em relação ao grupo controle, observamos que o número absoluto dos linfócitos Th1 e Th17, linfócitos responsáveis pela patogenia da EAE, estavam reduzidos, corroborando assim, com o fato dessas populações serem cruciais no estabelecimento da doença (Dardalhon, Korn et al. 2008).

Uma vez que a ativação desses linfócitos ocorre na periferia e, posteriormente migram para o cérebro, hipotetizamos que, um dos mecanismos de supressão das htMSCs, é diminuir a ativação dos mesmos. Na periferia, pudemos observar a diminuição da expressão das moléculas coestimuladoras CD80 e CD86, e também da molécula de superfície MHC II em células dendríticas nos linfonodos drenantes dos animais tratados com htMSCs. A modulação dessas moléculas por hMSCs é conhecida na literatura, e mostra que hMSCs derivadas de medula óssea podem afetar a diferenciação e a maturação de monócitos em células dendríticas exatamente por reduzir a expressão das moléculas CD80, CD86 e MHC II citadas acima (Jiang, Zhang et al. 2005)

Outras fontes de hMSCs utilizadas no tratamento da EAE obtiveram resultados semelhantes aos resultados apresentados nesse trabalho, como as hMSCs derivadas de medula óssea, cordão umbilical e placenta. Nesses estudos também foram observados redução do infiltrado inflamatório do SNC e medula espinhal (Hou, Ryu et al. 2013, Bravo, Gallego et al. 2016), diminuição da população Th1 e Th17 no SNC de camundongos tratados (Bai, Lennon et al. 
2009, Wang, Lazorchak et al. 2016), aumento da secreção de da citocina antiinflamatório IL-10 (Hou, Ryu et al. 2013, Payne, Sun et al. 2013).

Juntos, esses resultados indicam que a melhora na condição clínica observada após a administração de $h M S C$ s é uma consequência da inibição na proliferação e infiltração de células inflamatórias, como, Th1 e Th17 e monócitos no sistema nervoso central e medula espinhal promovida por essas células tronco. Pode-se hipotetizar que fatores secretados pelos hMSCs administrados, como IL-10, por exemplo, inibem a ativação de células T CD4+ auto-rreativas e sua diferenciação em células Th1 tanto na periferia quanto no sistema nervoso central e, talvez, estimulando a diferenciação dessas células $T$ CD4+ em linfócitos Treg.

Nossa análise de expressão gênica revelou a diminuição de expressão de receptores de citocinas quimiotáticas CCR4, CCR6 e CCR8. O receptor CCR4 é ligante da quimiocina CCL2, a qual sabidamente está envolvida nos processos neuroinflamatórios do SNC (Gerard and Rollins 2001). De fato, a secreção de CCL2 nas células da glia é aumentada na epilepsia (Fabene, Bramanti et al. 2010), na EM e no modelo da EAE (Ransohoff, Hamilton et al. 1993).

Em suma, nosso trabalho demonstrou que as $h t M S C s$ possuem de fato um efeito supressor, uma vez que reduzem a resposta inata e adaptativa resultando na redução no desenvolvimento da EAE. Células dendríticas tem sua capacidade de ativação reduzida na periferia, levando a diminuição da polarização de linfócitos T CD4+ para os perfis Th1 e Th17. Dessa forma, há diminuição do infiltrado inflamatório no cérebro, de linfócitos Th1, Th17 e, consequentemente, menor secreção de IFN-y e IL-17, e maior secreção de IL10. A microglia residente, por sua vez, encontra-se menos ativada e, na presença de BDNF e IDO, os linfócitos Th1 e Th17 autorreativos vindos da periferia tem sua ativação reduzida, impedindo o aumento da inflamação no SNC. A esse fato, relacionamos também a expressão reduzidas de receptores de quimiocinas CCR4, CCR8 e CCR6 na medula espinhal. Dessa forma, demonstramos o poder imunodulador e neuroprotetor das $h t M S C s$ no modelo 
da EAE, colaborando na descrição de uma nova fonte para o desenvolvimento de terapias futuras. 


\section{CONCLUSÕES}

- As htMSCs suprimem o estabelecimento dos sintomas e a progressão da doença em animais com EAE;

- htMSCs modulam a transcrição gênica na medula espinhal inibindo a transcrição de genes relacionados aos perfis Th1 e Th17 e aumentando a expressão de genes imunomoduladores;

- O tratamento com htMSCs diminui a expressão de moléculas coestimuladoras e expressão de MHC II em células dendríticas na periferia;

- As htMSCs impedem células inflamatórias de adentrar o SNC de animais com EAE, especificamente, os linfócitos patogênicos da doença de perfis Th1 e Th17, respectivamente;

- A microglia residente apresenta um perfil pouco ativado em animais tratados com htMSCs;

- As htMSCs induzem o aumento de citocinas antiinflamatórias como IL10, a enzima IDO e o fator neurotrófico BDNF; 


\section{REFERÊNCIAS}

Anderson, P., E. Gonzalez-Rey, F. O'Valle, F. Martin, F. J. Oliver and M. Delgado (2017). "Allogeneic Adipose-Derived Mesenchymal Stromal Cells Ameliorate Experimental Autoimmune Encephalomyelitis by Regulating Self-Reactive T Cell Responses and Dendritic Cell Function." Stem Cells Int 2017: 2389753.

Bai, L., D. P. Lennon, V. Eaton, K. Maier, A. I. Caplan, S. D. Miller and R. H. Miller (2009). "Human bone marrow-derived mesenchymal stem cells induce Th2-polarized immune response and promote endogenous repair in animal models of multiple sclerosis." Glia 57(11): 1192-1203.

Bailey, S. L., B. Schreiner, E. J. McMahon and S. D. Miller (2007). "CNS myeloid DCs presenting endogenous myelin peptides 'preferentially' polarize CD4+ T(H)-17 cells in relapsing EAE." Nat Immunol 8(2): $172-180$.

Barkhof, F., P. Scheltens, S. T. Frequin, J. J. Nauta, M. W. Tas, J. Valk and O. R. Hommes (1992). "Relapsing-remitting multiple sclerosis: sequential enhanced $\mathrm{MR}$ imaging vs clinical findings in determining disease activity." AJR Am J Roentgenol 159(5): 1041-1047.

Beyth, S., Z. Borovsky, D. Mevorach, M. Liebergall, Z. Gazit, H. Aslan, E. Galun and J. Rachmilewitz (2005). "Human mesenchymal stem cells alter antigen-presenting cell maturation and induce T-cell unresponsiveness." Blood 105(5): 2214-2219.

Bobis, S., D. Jarocha and M. Majka (2006). "Mesenchymal stem cells: characteristics and clinical applications." Folia Histochem Cytobiol 44(4): 215-230.

Bravo, B., M. I. Gallego, A. I. Flores, R. Bornstein, A. Puente-Bedia, J. Hernandez, P. de la Torre, E. GarciaZaragoza, R. Perez-Tavarez, J. Grande, A. Ballester and S. Ballester (2016). "Restrained Th17 response and myeloid cell infiltration into the central nervous system by human decidua-derived mesenchymal stem cells during experimental autoimmune encephalomyelitis." Stem Cell Res Ther 7: 43.

Bronner, G., E. Elran, J. Golomb and A. D. Korczyn (2010). "Female sexuality in multiple sclerosis: the multidimensional nature of the problem and the intervention." Acta Neurol Scand 121(5): 289-301.

Charcot, M. (1881). "Demonstration of Arthropathic Affections of Locomotor Ataxy." Br Med J 2(1076): 285.

Chen, M., G. Chen, S. Deng, X. Liu, G. J. Hutton and J. Hong (2012). "IFN-beta induces the proliferation of CD4+CD25+Foxp3+ regulatory $T$ cells through upregulation of GITRL on dendritic cells in the treatment of multiple sclerosis." J Neuroimmunol 242(1-2): 39-46.

Dardalhon, V., T. Korn, V. K. Kuchroo and A. C. Anderson (2008). "Role of Th1 and Th17 cells in organspecific autoimmunity." J Autoimmun 31(3): 252-256.

Das Sarma, J., B. Ciric, R. Marek, S. Sadhukhan, M. L. Caruso, J. Shafagh, D. C. Fitzgerald, K. S. Shindler and A. Rostami (2009). "Functional interleukin-17 receptor A is expressed in central nervous system glia and upregulated in experimental autoimmune encephalomyelitis." J Neuroinflammation 6: 14.

de Girolamo, L., E. Lucarelli, G. Alessandri, M. A. Avanzini, M. E. Bernardo, E. Biagi, A. T. Brini, G. D'Amico, F. Fagioli, I. Ferrero, F. Locatelli, R. Maccario, M. Marazzi, O. Parolini, A. Pessina, M. L. Torre and G. Italian Mesenchymal Stem Cell (2013). "Mesenchymal stem/stromal cells: a new "cells as drugs" paradigm. Efficacy and critical aspects in cell therapy." Curr Pharm Des 19(13): 2459-2473.

de Mendonca Costa, A., D. F. Bueno, M. T. Martins, I. Kerkis, A. Kerkis, R. D. Fanganiello, H. Cerruti, N. Alonso and M. R. Passos-Bueno (2008). "Reconstruction of large cranial defects in nonimmunosuppressed experimental design with human dental pulp stem cells." J Craniofac Surg 19(1): 204-210. 
DelaRosa, O., E. Lombardo, A. Beraza, P. Mancheno-Corvo, C. Ramirez, R. Menta, L. Rico, E. Camarillo, L. Garcia, J. L. Abad, C. Trigueros, M. Delgado and D. Buscher (2009). "Requirement of IFN-gammamediated indoleamine 2,3-dioxygenase expression in the modulation of lymphocyte proliferation by human adipose-derived stem cells." Tissue Eng Part A 15(10): 2795-2806.

Dominici, M., K. Le Blanc, I. Mueller, I. Slaper-Cortenbach, F. Marini, D. Krause, R. Deans, A. Keating, D. Prockop and E. Horwitz (2006). "Minimal criteria for defining multipotent mesenchymal stromal cells. The International Society for Cellular Therapy position statement." Cytotherapy 8(4): 315-317.

Donders, R., J. F. J. Bogie, S. Ravanidis, P. Gervois, M. Vanheusden, R. Maree, M. Schrynemackers, H. J. M. Smeets, J. Pinxteren, K. Gijbels, S. Walbers, R. W. Mays, R. Deans, L. Van Den Bosch, P. Stinissen, I. Lambrichts, W. Gyselaers and N. Hellings (2018). "Human Wharton's Jelly-Derived Stem Cells Display a Distinct Immunomodulatory and Proregenerative Transcriptional Signature Compared to Bone MarrowDerived Stem Cells." Stem Cells Dev 27(2): 65-84.

Donders, R., M. Vanheusden, J. F. Bogie, S. Ravanidis, K. Thewissen, P. Stinissen, W. Gyselaers, J. J. Hendriks and N. Hellings (2015). "Human Wharton's Jelly-Derived Stem Cells Display Immunomodulatory Properties and Transiently Improve Rat Experimental Autoimmune Encephalomyelitis." Cell Transplant 24(10): 2077-2098.

Duijvestein, M., M. E. Wildenberg, M. M. Welling, S. Hennink, I. Molendijk, V. L. van Zuylen, T. Bosse, A. C. Vos, E. S. de Jonge-Muller, H. Roelofs, L. van der Weerd, H. W. Verspaget, W. E. Fibbe, A. A. te Velde, G. R. van den Brink and D. W. Hommes (2011). "Pretreatment with interferon-gamma enhances the therapeutic activity of mesenchymal stromal cells in animal models of colitis." Stem Cells 29(10): 15491558.

Evangelista, M., M. Soncini and O. Parolini (2008). "Placenta-derived stem cells: new hope for cell therapy?" Cytotechnology 58(1): 33-42.

Fabene, P. F., P. Bramanti and G. Constantin (2010). "The emerging role for chemokines in epilepsy." J Neuroimmunol 224(1-2): 22-27.

Filippi, M., M. A. Rocca, G. Martino, M. A. Horsfield and G. Comi (1998). "Magnetization transfer changes in the normal appearing white matter precede the appearance of enhancing lesions in patients with multiple sclerosis." Ann Neurol 43(6): 809-814.

Finkelsztejn, A., J. S. Lopes, J. Noal and J. M. Finkelsztejn (2014). "The prevalence of multiple sclerosis in Santa Maria, Rio Grande do Sul, Brazil." Arq Neuropsiquiatr 72(2): 104-106.

Freedman, M. S. (2013). "Teriflunomide in relapsing multiple sclerosis: therapeutic utility." Ther Adv Chronic Dis 4(5): 192-205.

Friese, M. A., X. Montalban, N. Willcox, J. I. Bell, R. Martin and L. Fugger (2006). "The value of animal models for drug development in multiple sclerosis." Brain 129(Pt 8): 1940-1952.

Frota, E. R., D. H. Rodrigues, E. A. Donadi, D. G. Brum, D. R. Maciel and A. L. Teixeira (2009). "Increased plasma levels of brain derived neurotrophic factor (BDNF) after multiple sclerosis relapse." Neurosci Lett 460(2): 130-132.

Fuenzalida, P., M. Kurte, C. Fernandez-O'ryan, C. Ibanez, M. Gauthier-Abeliuk, A. M. Vega-Letter, P. Gonzalez, C. Irarrazabal, N. Quezada, F. Figueroa and F. Carrion (2016). "Toll-like receptor 3 preconditioning increases the therapeutic efficacy of umbilical cord mesenchymal stromal cells in a dextran sulfate sodium-induced colitis model." Cytotherapy 18(5): 630-641.

Gargett, C. E. (2007). "Uterine stem cells: what is the evidence?" Hum Reprod Update 13(1): 87-101.

Gerard, C. and B. J. Rollins (2001). "Chemokines and disease." Nat Immunol 2(2): 108-115. 
Giacoppo, S., S. R. Thangavelu, F. Diomede, P. Bramanti, P. Conti, O. Trubiani and E. Mazzon (2017). "Anti-inflammatory effects of hypoxia-preconditioned human periodontal ligament cell secretome in an experimental model of multiple sclerosis: a key role of IL-37." FASEB J 31(12): 5592-5608.

Gold, R., L. Kappos, D. L. Arnold, A. Bar-Or, G. Giovannoni, K. Selmaj, C. Tornatore, M. T. Sweetser, M. Yang, S. I. Sheikh, K. T. Dawson and D. S. Investigators (2012). "Placebo-controlled phase 3 study of oral BG-12 for relapsing multiple sclerosis." N EngI J Med 367(12): 1098-1107.

Goverman, J., A. Perchellet and E. S. Huseby (2005). "The role of CD8(+) T cells in multiple sclerosis and its animal models." Curr Drug Targets Inflamm Allergy 4(2): 239-245.

Grzesiuk, A. K. (2006). "[Clinical and epidemiologic characteristics of 20 patients with multiple sclerosis in Cuiaba-Mato Grosso, Brazil]." Arq Neuropsiquiatr 64(3A): 635-638.

Han, X., Q. Yang, L. Lin, C. Xu, C. Zheng, X. Chen, Y. Han, M. Li, W. Cao, K. Cao, Q. Chen, G. Xu, Y. Zhang, J. Zhang, R. J. Schneider, Y. Qian, Y. Wang, G. Brewer and Y. Shi (2014). "Interleukin-17 enhances immunosuppression by mesenchymal stem cells." Cell Death Differ 21(11): 1758-1768.

Hauser, S. L. and J. R. Oksenberg (2006). "The neurobiology of multiple sclerosis: genes, inflammation, and neurodegeneration." Neuron 52(1): 61-76.

Havla, J., L. A. Gerdes, I. Meinl, M. Krumbholz, H. Faber, F. Weber, H. L. Pellkofer, R. Hohlfeld and T. Kumpfel (2011). "De-escalation from natalizumab in multiple sclerosis: recurrence of disease activity despite switching to glatiramer acetate." J Neurol 258(9): 1665-1669.

Hirota, K., J. H. Duarte, M. Veldhoen, E. Hornsby, Y. Li, D. J. Cua, H. Ahlfors, C. Wilhelm, M. Tolaini, U. Menzel, A. Garefalaki, A. J. Potocnik and B. Stockinger (2011). "Fate mapping of IL-17-producing T cells in inflammatory responses." Nat Immunol 12(3): 255-263.

Hou, Y., C. H. Ryu, K. Y. Park, S. M. Kim, C. H. Jeong and S. S. Jeun (2013). "Effective combination of human bone marrow mesenchymal stem cells and minocycline in experimental autoimmune encephalomyelitis mice." Stem Cell Res Ther 4(4): 77.

Ireland, S. and N. Monson (2011). "Potential impact of B cells on T cell function in multiple sclerosis." Mult Scler Int 2011: 423971.

Ivanov, II, B. S. McKenzie, L. Zhou, C. E. Tadokoro, A. Lepelley, J. J. Lafaille, D. J. Cua and D. R. Littman (2006). "The orphan nuclear receptor RORgammat directs the differentiation program of proinflammatory IL-17+ T helper cells." Cell 126(6): 1121-1133.

Jacobs, L. D., R. W. Beck, J. H. Simon, R. P. Kinkel, C. M. Brownscheidle, T. J. Murray, N. A. Simonian, P. J. Slasor and A. W. Sandrock (2000). "Intramuscular interferon beta-1a therapy initiated during a first demyelinating event in multiple sclerosis. CHAMPS Study Group." N Engl J Med 343(13): 898-904.

Jacobs, L. D., D. L. Cookfair, R. A. Rudick, R. M. Herndon, J. R. Richert, A. M. Salazar, J. S. Fischer, D. E. Goodkin, C. V. Granger, J. H. Simon, J. J. Alam, D. M. Bartoszak, D. N. Bourdette, J. Braiman, C. M. Brownscheidle, M. E. Coats, S. L. Cohan, D. S. Dougherty, R. P. Kinkel, M. K. Mass, F. E. Munschauer, 3rd, R. L. Priore, P. M. Pullicino, B. J. Scherokman, R. H. Whitham and et al. (1996). "Intramuscular interferon beta-1a for disease progression in relapsing multiple sclerosis. The Multiple Sclerosis Collaborative Research Group (MSCRG)." Ann Neurol 39(3): 285-294.

Jazedje, T., P. M. Perin, C. E. Czeresnia, M. Maluf, S. Halpern, M. Secco, D. F. Bueno, N. M. Vieira, E. Zucconi and M. Zatz (2009). "Human fallopian tube: a new source of multipotent adult mesenchymal stem cells discarded in surgical procedures." J Transl Med 7: 46.

Jiang, X. X., Y. Zhang, B. Liu, S. X. Zhang, Y. Wu, X. D. Yu and N. Mao (2005). "Human mesenchymal stem cells inhibit differentiation and function of monocyte-derived dendritic cells." Blood 105(10): 4120-4126. 
Kabat, E. A., A. Wolf and A. E. Bezer (1947). "The Rapid Production of Acute Disseminated Encephalomyelitis in Rhesus Monkeys by Injection of Heterologous and Homologous Brain Tissue with Adjuvants." J Exp Med 85(1): 117-130.

Kang, Z., C. Z. Altuntas, M. F. Gulen, C. Liu, N. Giltiay, H. Qin, L. Liu, W. Qian, R. M. Ransohoff, C. Bergmann, S. StohIman, V. K. Tuohy and X. Li (2010). "Astrocyte-restricted ablation of interleukin-17induced Act1-mediated signaling ameliorates autoimmune encephalomyelitis." Immunity 32(3): 414425.

Kawanokuchi, J., K. Shimizu, A. Nitta, K. Yamada, T. Mizuno, H. Takeuchi and A. Suzumura (2008). "Production and functions of IL-17 in microglia." J Neuroimmunol 194(1-2): 54-61.

Kim, K. W., S. J. Moon, M. J. Park, B. M. Kim, E. K. Kim, S. H. Lee, E. J. Lee, B. H. Chung, C. W. Yang and M. L. Cho (2015). "Optimization of adipose tissue-derived mesenchymal stem cells by rapamycin in a murine model of acute graft-versus-host disease." Stem Cell Res Ther 6: 202.

Komiyama, Y., S. Nakae, T. Matsuki, A. Nambu, H. Ishigame, S. Kakuta, K. Sudo and Y. Iwakura (2006). "IL-17 plays an important role in the development of experimental autoimmune encephalomyelitis." J Immunol 177(1): 566-573.

Krampera, M., L. Cosmi, R. Angeli, A. Pasini, F. Liotta, A. Andreini, V. Santarlasci, B. Mazzinghi, G. Pizzolo, F. Vinante, P. Romagnani, E. Maggi, S. Romagnani and F. Annunziato (2006). "Role for interferon-gamma in the immunomodulatory activity of human bone marrow mesenchymal stem cells." Stem Cells 24(2): 386-398.

Kreymborg, K., R. Etzensperger, L. Dumoutier, S. Haak, A. Rebollo, T. Buch, F. L. Heppner, J. C. Renauld and B. Becher (2007). "IL-22 is expressed by Th17 cells in an IL-23-dependent fashion, but not required for the development of autoimmune encephalomyelitis." J Immunol 179(12): 8098-8104.

Krumbholz, M., T. Derfuss, R. Hohlfeld and E. Meinl (2012). "B cells and antibodies in multiple sclerosis pathogenesis and therapy." Nat Rev Neurol 8(11): 613-623.

Le Blanc, K. and D. Mougiakakos (2012). "Multipotent mesenchymal stromal cells and the innate immune system." Nat Rev Immunol 12(5): 383-396.

Lee, H. J., J. H. Ko, H. J. Jeong, A. Y. Ko, M. K. Kim, W. R. Wee, S. O. Yoon and J. Y. Oh (2015). "Mesenchymal stem/stromal cells protect against autoimmunity via CCL2-dependent recruitment of myeloid-derived suppressor cells." J Immunol 194(8): 3634-3645.

Lee, R. H., A. A. Pulin, M. J. Seo, D. J. Kota, J. Ylostalo, B. L. Larson, L. Semprun-Prieto, P. Delafontaine and D. J. Prockop (2009). "Intravenous hMSCs improve myocardial infarction in mice because cells embolized in lung are activated to secrete the anti-inflammatory protein TSG-6." Cell Stem Cell 5(1): 5463.

Liao, W., V. Pham, L. Liu, M. Riazifar, E. J. Pone, S. X. Zhang, F. Ma, M. Lu, C. M. Walsh and W. Zhao (2016). "Mesenchymal stem cells engineered to express selectin ligands and IL-10 exert enhanced therapeutic efficacy in murine experimental autoimmune encephalomyelitis." Biomaterials 77: 87-97.

Link, J., R. Ramanujam, M. Auer, M. Ryner, S. Hassler, D. Bachelet, C. Mbogning, C. Warnke, D. Buck, P. E. Hyldgaard Jensen, C. Sievers, K. Ingenhoven, N. Fissolo, R. Lindberg, V. Grummel, N. Donnellan, M. Comabella, X. Montalban, B. Kieseier, P. Soelberg Sorensen, H. P. Hartung, T. Derfuss, A. Lawton, D. Sikkema, M. Pallardy, B. Hemmer, F. Deisenhammer, P. Broet, P. Donnes, J. Davidson, A. Fogdell-Hahn and A. Consortium (2017). "Clinical practice of analysis of anti-drug antibodies against interferon beta and natalizumab in multiple sclerosis patients in Europe: A descriptive study of test results." PLoS One 12(2): e0170395. 
Liu, R., Z. Zhang, Z. Lu, C. Borlongan, J. Pan, J. Chen, L. Qian, Z. Liu, L. Zhu, J. Zhang and Y. Xu (2013). "Human umbilical cord stem cells ameliorate experimental autoimmune encephalomyelitis by regulating immunoinflammation and remyelination." Stem Cells Dev 22(7): 1053-1062.

Locatelli, F., R. Maccario and F. Frassoni (2007). "Mesenchymal stromal cells, from indifferent spectators to principal actors. Are we going to witness a revolution in the scenario of allograft and immunemediated disorders?" Haematologica 92(7): 872-877.

Luz-Crawford, P., M. J. Torres, D. Noel, A. Fernandez, K. Toupet, F. Alcayaga-Miranda, G. Tejedor, C. Jorgensen, S. E. Illanes, F. E. Figueroa, F. Djouad and M. Khoury (2016). "The immunosuppressive signature of menstrual blood mesenchymal stem cells entails opposite effects on experimental arthritis and graft versus host diseases." Stem Cells 34(2): 456-469.

Lyons, R. A., E. Saridogan and O. Djahanbakhch (2006). "The reproductive significance of human Fallopian tube cilia." Hum Reprod Update 12(4): 363-372.

Miller, S. D., C. L. Vanderlugt, W. S. Begolka, W. Pao, R. L. Yauch, K. L. Neville, Y. Katz-Levy, A. Carrizosa and B. S. Kim (1997). "Persistent infection with Theiler's virus leads to CNS autoimmunity via epitope spreading." Nat Med 3(10): 1133-1136.

Moreno Torres, I. and A. Garcia-Merino (2017). "Anti-CD20 monoclonal antibodies in multiple sclerosis." Expert Rev Neurother 17(4): 359-371.

Nemeth, K., A. Keane-Myers, J. M. Brown, D. D. Metcalfe, J. D. Gorham, V. G. Bundoc, M. G. Hodges, I. Jelinek, S. Madala, S. Karpati and E. Mezey (2010). "Bone marrow stromal cells use TGF-beta to suppress allergic responses in a mouse model of ragweed-induced asthma." Proc Natl Acad Sci U S A 107(12): 5652-5657.

Nemeth, K., A. Leelahavanichkul, P. S. Yuen, B. Mayer, A. Parmelee, K. Doi, P. G. Robey, K. Leelahavanichkul, B. H. Koller, J. M. Brown, X. Hu, I. Jelinek, R. A. Star and E. Mezey (2009). "Bone marrow stromal cells attenuate sepsis via prostaglandin $E(2)$-dependent reprogramming of host macrophages to increase their interleukin-10 production." Nat Med 15(1): 42-49.

O'Connor, R. A., C. T. Prendergast, C. A. Sabatos, C. W. Lau, M. D. Leech, D. C. Wraith and S. M. Anderton (2008). "Cutting edge: Th1 cells facilitate the entry of Th17 cells to the central nervous system during experimental autoimmune encephalomyelitis." J Immunol 181(6): 3750-3754.

Olah, M., S. Amor, N. Brouwer, J. Vinet, B. Eggen, K. Biber and H. W. Boddeke (2012). "Identification of a microglia phenotype supportive of remyelination." Glia 60(2): 306-321.

Ortiz, L. A., M. Dutreil, C. Fattman, A. C. Pandey, G. Torres, K. Go and D. G. Phinney (2007). "Interleukin 1 receptor antagonist mediates the antiinflammatory and antifibrotic effect of mesenchymal stem cells during lung injury." Proc Natl Acad Sci U S A 104(26): 11002-11007.

Park, M. J., S. K. Kwok, S. H. Lee, E. K. Kim, S. H. Park and M. L. Cho (2015). "Adipose tissue-derived mesenchymal stem cells induce expansion of interleukin-10-producing regulatory $B$ cells and ameliorate autoimmunity in a murine model of systemic lupus erythematosus." Cell Transplant 24(11): 2367-2377.

Payne, N. L., G. Sun, C. McDonald, D. Layton, L. Moussa, A. Emerson-Webber, N. Veron, C. Siatskas, D. Herszfeld, J. Price and C. C. Bernard (2013). "Distinct immunomodulatory and migratory mechanisms underpin the therapeutic potential of human mesenchymal stem cells in autoimmune demyelination." Cell Transplant 22(8): 1409-1425.

Peron, J. P., T. Jazedje, W. N. Brandao, P. M. Perin, M. Maluf, L. P. Evangelista, S. Halpern, M. G. Nisenbaum, C. E. Czeresnia, M. Zatz, N. O. Camara and L. V. Rizzo (2012). "Human endometrial-derived mesenchymal stem cells suppress inflammation in the central nervous system of EAE mice." Stem Cell Rev 8(3): 940-952. 
Peron, J. P., K. Yang, M. L. Chen, W. N. Brandao, A. S. Basso, A. G. Commodaro, H. L. Weiner and L. V. Rizzo (2010). "Oral tolerance reduces Th17 cells as well as the overall inflammation in the central nervous system of EAE mice." J Neuroimmunol 227(1-2): 10-17.

Pettinelli, C. B. and D. E. McFarlin (1981). "Adoptive transfer of experimental allergic encephalomyelitis in SJL/J mice after in vitro activation of lymph node cells by myelin basic protein: requirement for Lyt 1+ 2- T lymphocytes." J Immunol 127(4): 1420-1423.

Phinney, D. G. and D. J. Prockop (2007). "Concise review: mesenchymal stem/multipotent stromal cells: the state of transdifferentiation and modes of tissue repair--current views." Stem Cells 25(11): 28962902.

Pilote, S., C. Simard and B. Drolet (2017). "Fingolimod (Gilenya(R) ) in multiple sclerosis: bradycardia, atrioventricular blocks, and mild effect on the QTc interval. Something to do with the L-type calcium channel?" Fundam Clin Pharmacol.

Ponomarev, E. D., L. P. Shriver, K. Maresz and B. N. Dittel (2005). "Microglial cell activation and proliferation precedes the onset of CNS autoimmunity." J Neurosci Res 81(3): 374-389.

Prajeeth, C. K., O. Dittrich-Breiholz, S. R. Talbot, P. A. Robert, J. Huehn and M. Stangel (2018). "IFNgamma Producing Th1 Cells Induce Different Transcriptional Profiles in Microglia and Astrocytes." Front Cell Neurosci 12: 352.

Rafei, M., P. M. Campeau, A. Aguilar-Mahecha, M. Buchanan, P. Williams, E. Birman, S. Yuan, Y. K. Young, M. N. Boivin, K. Forner, M. Basik and J. Galipeau (2009). "Mesenchymal stromal cells ameliorate experimental autoimmune encephalomyelitis by inhibiting CD4 Th17 T cells in a CC chemokine ligand 2dependent manner." J Immunol 182(10): 5994-6002.

Ransohoff, R. M., T. A. Hamilton, M. Tani, M. H. Stoler, H. E. Shick, J. A. Major, M. L. Estes, D. M. Thomas and V. K. Tuohy (1993). "Astrocyte expression of mRNA encoding cytokines IP-10 and JE/MCP-1 in experimental autoimmune encephalomyelitis." FASEB J 7(6): 592-600.

Ren, G., L. Zhang, X. Zhao, G. Xu, Y. Zhang, A. I. Roberts, R. C. Zhao and Y. Shi (2008). "Mesenchymal stem cell-mediated immunosuppression occurs via concerted action of chemokines and nitric oxide." Cell Stem Cell 2(2): 141-150.

Ren, G., X. Zhao, L. Zhang, J. Zhang, A. L'Huillier, W. Ling, A. I. Roberts, A. D. Le, S. Shi, C. Shao and Y. Shi (2010). "Inflammatory cytokine-induced intercellular adhesion molecule-1 and vascular cell adhesion molecule-1 in mesenchymal stem cells are critical for immunosuppression." J Immunol 184(5): 23212328.

Rodriguez, M. (2007). "Effectors of demyelination and remyelination in the CNS: implications for multiple sclerosis." Brain Pathol 17(2): 219-229.

Rothhammer, V., S. Heink, F. Petermann, R. Srivastava, M. C. Claussen, B. Hemmer and T. Korn (2011). "Th17 lymphocytes traffic to the central nervous system independently of alpha4 integrin expression during EAE." J Exp Med 208(12): 2465-2476.

Ruck, T., A. M. Afzali, K. F. Lukat, M. Eveslage, C. C. Gross, S. Pfeuffer, S. Bittner, L. Klotz, N. Melzer, H. Wiendl and S. G. Meuth (2016). "ALAIN01--Alemtuzumab in autoimmune inflammatory neurodegeneration: mechanisms of action and neuroprotective potential." BMC Neurol 16: 34.

Sanchez-de la Rosa, R., E. Sabater, M. A. Casado and R. Arroyo (2012). "Cost-effectiveness analysis of disease modifiying drugs (interferons and glatiramer acetate) as first line treatments in remittingrelapsing multiple sclerosis patients." J Med Econ 15(3): 424-433. 
Secco, M., E. Zucconi, N. M. Vieira, L. L. Fogaca, A. Cerqueira, M. D. Carvalho, T. Jazedje, O. K. Okamoto, A. R. Muotri and M. Zatz (2008). "Multipotent stem cells from umbilical cord: cord is richer than blood!" Stem Cells 26(1): 146-150.

Selim, A. O., S. A. Selim, S. M. Shalaby, H. Mosaad and T. Saber (2016). "Neuroprotective effects of placenta-derived mesenchymal stromal cells in a rat model of experimental autoimmune encephalomyelitis." Cytotherapy 18(9): 1100-1113.

Shalaby, S. M., N. A. Sabbah, T. Saber and R. A. Abdel Hamid (2016). "Adipose-derived mesenchymal stem cells modulate the immune response in chronic experimental autoimmune encephalomyelitis model." IUBMB Life 68(2): 106-115.

Shi, Y., J. Su, A. I. Roberts, P. Shou, A. B. Rabson and G. Ren (2012). "How mesenchymal stem cells interact with tissue immune responses." Trends Immunol 33(3): 136-143.

Shimojima, C., H. Takeuchi, S. Jin, B. Parajuli, H. Hattori, A. Suzumura, H. Hibi, M. Ueda and A. Yamamoto (2016). "Conditioned Medium from the Stem Cells of Human Exfoliated Deciduous Teeth Ameliorates Experimental Autoimmune Encephalomyelitis." J Immunol 196(10): 4164-4171.

Spaggiari, G. M., H. Abdelrazik, F. Becchetti and L. Moretta (2009). "MSCs inhibit monocyte-derived DC maturation and function by selectively interfering with the generation of immature DCs: central role of MSC-derived prostaglandin E2." Blood 113(26): 6576-6583.

Tafreshi, A. P., N. Payne, G. Sun, A. Sylvain, K. Schulze and C. Bernard (2014). "Inactive GSK3beta is disturbed in the spinal cord during experimental autoimmune encephalomyelitis, but rescued by stem cell therapy." Neuroscience 277: 498-505.

Torkaman, M., M. Ghollasi, M. Mohammadnia-Afrouzi, A. Salimi and A. Amari (2017). "The effect of transplanted human Wharton's jelly mesenchymal stem cells treated with IFN-gamma on experimental autoimmune encephalomyelitis mice." Cell Immunol 311: 1-12.

Uccelli, A., L. Moretta and V. Pistoia (2008). "Mesenchymal stem cells in health and disease." Nat Rev Immunol 8(9): 726-736.

Valtieri, M. and A. Sorrentino (2008). "The mesenchymal stromal cell contribution to homeostasis." J Cell Physiol 217(2): 296-300.

Wang, X., E. A. Kimbrel, K. Ijichi, D. Paul, A. S. Lazorchak, J. Chu, N. A. Kouris, G. J. Yavanian, S. J. Lu, J. S. Pachter, S. J. Crocker, R. Lanza and R. H. Xu (2014). "Human ESC-derived MSCs outperform bone marrow MSCs in the treatment of an EAE model of multiple sclerosis." Stem Cell Reports 3(1): 115-130.

Wang, X., A. S. Lazorchak, L. Song, E. Li, Z. Zhang, B. Jiang and R. H. Xu (2016). "Immune modulatory mesenchymal stem cells derived from human embryonic stem cells through a trophoblast-like stage." Stem Cells 34(2): 380-391.

Warburton, D., L. Perin, R. Defilippo, S. Bellusci, W. Shi and B. Driscoll (2008). "Stem/progenitor cells in lung development, injury repair, and regeneration." Proc Am Thorac Soc 5(6): 703-706.

Zhang, M. J., B. Liu, W. Xia, Z. Y. Sun and K. H. Lu (2009). "Could cells from menstrual blood be a new source for cell-based therapies?" Med Hypotheses 72(3): 252-254.

Zhang, W., W. Ge, C. Li, S. You, L. Liao, Q. Han, W. Deng and R. C. Zhao (2004). "Effects of mesenchymal stem cells on differentiation, maturation, and function of human monocyte-derived dendritic cells." Stem Cells Dev 13(3): 263-271. 
Zhou, L., Ivanov, II, R. Spolski, R. Min, K. Shenderov, T. Egawa, D. E. Levy, W. J. Leonard and D. R. Littman (2007). "IL-6 programs T(H)-17 cell differentiation by promoting sequential engagement of the IL-21 and IL-23 pathways." Nat Immunol 8(9): 967-974.

Sites visitados:

- Multiple Sclerosis International Federation: Disponível em https://www.msif.org/about-us/who-we-are-and-what-we-do/advocacy/atlas/ 


\section{Anexos}

- The Brazilian Zika virus strain causes birth defects in experimental models.

Cugola, F.R., Fernandes, I.R., Russo, F.B., Freitas, B.C., Dias, J.L., Guimarães, K.P., Benazzato, C., Almeida, N., Pignatari, G.C., Romero, S., Polonio, C.M., Cunha, I., Freitas, C.L., Brandão, W.N., Rossato, C., Andrade, D.G., Faria, D.P., Garcez, A.T., Buchpigel, C.A., Braconi, C.T., Mendes, E., Sall, A.A., Zanotto, P.M., Peron, J.P., Muotri, A.R., BeltrãoBraga, P.C.

- Zika virus congenital syndrome: experimental models and clinical aspects.

Polonio, C.M., de Freitas, C.L., Zanluqui, N.G., Peron, J.P.S. 


\section{The Brazilian Zika virus strain causes birth defects in experimental models}

Fernanda R. Cugola ${ }^{1 *}$, Isabella R. Fernandes ${ }^{1,2 *}$, Fabiele B. Russo ${ }^{1,3 *}$, Beatriz C. Freitas ${ }^{2}$, João L. M. Dias ${ }^{1}$, Katia P. Guimarães ${ }^{1}$, Cecília Benazzato $^{1}$, Nathalia Almeida ${ }^{1}$, Graciela C. Pignatari ${ }^{1,3}$, Sarah Romero ${ }^{2}$, Carolina M. Polonio ${ }^{4}$, Isabela Cunha ${ }^{4}$, Carla L. Freitas ${ }^{4}$, Wesley N. Brandão ${ }^{4}$, Cristiano Rossato ${ }^{4}$, David G. Andrade ${ }^{4}$, Daniele de P. Faria ${ }^{5}$, Alexandre T. Garcez ${ }^{5}$, Carlos A. Buchpigel ${ }^{5}$, Carla T. Braconi ${ }^{6}$, Erica Mendes ${ }^{6}$, Amadou A. Sall ${ }^{7}$, Paolo M. de A. Zanotto ${ }^{6}$, Jean Pierre S. Peron ${ }^{4}$, Alysson R. Muotri ${ }^{2}$ \& Patricia C. B. Beltrão-Braga ${ }^{1,8}$

\begin{abstract}
Zika virus (ZIKV) is an arbovirus belonging to the genus Flavivirus (family Flaviviridae) and was first described in 1947 in Uganda following blood analyses of sentinel rhesus monkeys ${ }^{1}$. Until the twentieth century, the African and Asian lineages of the virus did not cause meaningful infections in humans. However, in 2007, vectored by Aedes aegypti mosquitoes, ZIKV caused the first noteworthy epidemic on Yap Island in Micronesia ${ }^{2}$. Patients experienced fever, skin rash, arthralgia and conjunctivitis ${ }^{2}$. From 2013 to 2015 , the Asian lineage of the virus caused further massive outbreaks in New Caledonia and French Polynesia. In 2013, ZIKV reached Brazil, later spreading to other countries in South and Central America ${ }^{3}$. In Brazil, the virus has been linked to congenital malformations, including microcephaly and other severe neurological diseases, such as Guillain-Barré syndrome $e^{4,5}$. Despite clinical evidence, direct experimental evidence showing that the Brazilian $\mathrm{ZIKV}\left(\mathrm{ZIKV}{ }^{\mathrm{BR}}\right)$ strain causes birth defects remains absent ${ }^{6}$. Here we demonstrate that $\mathrm{ZIKV}^{\mathrm{BR}}$ infects fetuses, causing intrauterine growth restriction, including signs of microcephaly, in mice. Moreover, the virus infects human cortical progenitor cells in vitro, leading to an increase in cell death. We also report that the infection of human brain organoids results in a reduction of proliferative zones and disrupted cortical layers. These results indicate that $\mathrm{ZIKV}^{\mathrm{BR}}$ crosses the placenta and causes microcephaly by targeting cortical progenitor cells, inducing cell death by apoptosis and autophagy, and impairing neurodevelopment. Our data reinforce the growing body of evidence linking the $\mathrm{ZIKV}^{\mathrm{BR}}$ outbreak to the alarming number of cases of congenital brain malformations. Our model can be used to determine the efficiency of therapeutic approaches to counteracting the harmful impact of $\mathrm{ZIKV}^{\mathrm{BR}}$ in human neurodevelopment.
\end{abstract}

The recent increase in microcephaly cases in Brazil has been associated with the outbreak of $\mathrm{Zika}$ virus (ZIKV) ${ }^{7}$, originating from an Asian-lineage strain that can be spread by Ae. aegypti mosquitoes ${ }^{8}$. The Brazilian ZIKV ( $\left.\mathrm{ZIKV}^{\mathrm{BR}}\right)$ has been detected in the placenta and amniotic fluid of two women with microcephalic fetuses ${ }^{9-11}$ and in the blood of microcephalic newborns ${ }^{10,12}$, suggesting that the virus can cross the placental membrane. The virus has also been identified in the brains and retinas of microcephalic fetuses ${ }^{11-13}$. However, there is no direct evidence of the mechanism by which $\mathrm{ZIKV}{ }^{\mathrm{BR}}$ might cause brain malformations. A previous study revealed that the African ZIKV $\left(\mathrm{ZIKV}{ }^{\mathrm{AF}}\right.$, strain MR-766) has the ability to infect human skin cells ${ }^{14}$. Neurons and astrocytes in the mouse brain could also be infected, inducing hippocampal degeneration and necrosis of pyriform cells
7 days post-infection ${ }^{15}$. More recently, $\mathrm{ZIKV}^{\mathrm{AF}}$ was also shown to infect human pluripotent stem cell (hPSC)-derived neural progenitor cells (NPCs) in vitro, which induced apoptotic cell death ${ }^{16}$. These studies were performed using the MR-766 ZIKV ${ }^{\mathrm{AF}}$ strain isolated in Uganda in 1947, which shares $87-90 \%$ sequence similarity with the Polynesian and Brazilian isolates ${ }^{3,17}$. Nevertheless, because severe congenital malformations were not reported for African isolates, there is a need to study the association of ZIKV with microcephaly and birth defects with isolates from affected localities, such as the $\mathrm{ZIKV}^{\mathrm{BR}}$ strain. Therefore, there is an urgent need to develop model systems to determine the relationship between infection with the ZIKV ${ }^{\mathrm{BR}}$ strain and birth defects.

We used $\mathrm{ZIKV}^{\mathrm{BR}}$ isolated from a febrile case in the state of Paraiba, in the northeast of Brazil in 2015 (see Methods). To evaluate the causal relationship between $\mathrm{ZIKV}{ }^{\mathrm{BR}}$ and birth defects, including brain malformation during development, we first used a murine experimental model in which SJL and C57BL/6 pregnant mice were infected with $\mathrm{ZIKV}^{\mathrm{BR}}$, evaluating newborns immediately after birth (Extended Data Fig. 1a). Notably, similar to ZIKV ${ }^{\mathrm{BR}}$-infected human newborns ${ }^{18,19}$, pups born from the SJL ZIKV ${ }^{B R}$-infected pregnant females displayed clear evidence of whole-body growth delay or intrauterine growth restriction (IUGR) ${ }^{20}$ compared to pups born from the mock-infected controls (Fig. 1a, b). Using a qPCR assay, we confirmed the presence of $\mathrm{ZIKV}^{\mathrm{BR}}$ genomic RNA in several tissues of newborn animals, observing significantly more viral RNA in the brain, confirming the neurotropic nature of the virus (Fig. 1c).

Microcephaly is perhaps the most striking of the birth defects reported in $\mathrm{ZIKV}^{\mathrm{BR}}$-infected newborns ${ }^{4,18,19}$. Mouse models often fail to reproduce the severely reduced brain size and pathological alterations found in human patients $\mathrm{s}^{21,22}$, probably owing to differences in gestation time and brain development between the two species. Nevertheless, upon close inspection of the $\mathrm{ZIKV}^{\mathrm{BR}}$-infected mouse brains, we noticed cortical malformations in the surviving animals, with reduced cell number and cortical layer thickness, signs associated with microcephaly in humans (Fig. 1d-f). At a cellular level, the neurons in the cortex, thalamus and hypothalamus displayed a 'vacuolar nuclei' appearance. This morphology was characterized by central emptiness and marginalized chromatin pattern with nuclear debris, suggesting ongoing cellular death (Fig. $1 \mathrm{~d}$ and Extended Data Fig. 2). In addition, we also noticed apparent ocular abnormalities, reminiscent of that observed in human patients ${ }^{23}$ (Fig. 1g). Thus, SJL infected pups presented congenital malformations with similarities to those in $Z I K V^{B R}$-infected human newborns. While the impact of $Z I_{K V} V^{B R}$

University of São Paulo, Department of Surgery, Stem Cell Laboratory, São Paulo, São Paulo 05508-270, Brazil. 2University of California San Diego, School of Medicine, Department of Pediatrics/ Rady Children's Hospital San Diego, Department of Cellular \& Molecular Medicine, Stem Cell Program, La Jolla, California 92037-0695, USA. 3Tismoo, The Biotech Company, São Paulo, São Paulo 01401-000, Brazil. “University of São Paulo, Department of Immunology, Neuroimmune Interactions Laboratory, São Paulo, São Paulo 05508-000, Brazil. 5University of São Paulo, Department of Radiology and Oncology, USP School of Medicine, São Paulo, São Paulo 05403-010, Brazil. 'EUniversity of São Paulo, Department of Microbiology, Institute of Microbiology Sciences, Laboratory of Molecular Evolution and Bioinformatics, São Paulo, São Paulo 05508-000, Brazil. '7nstitute Pasteur in Dakar, Dakar 220, Sénégal. 8University of São Paulo, School of Arts, Sciences and Humanities, Department of Obstetrics, São Paulo, São Paulo 03828-000, Brazil

*These authors contributed equally to this work. 


\title{
Zika virus congenital syndrome: experimental models and clinical aspects
}

Carolina Manganeli Polonio, Carla Longo de Freitas, Nagela Ghabdan Zanluqui and Jean Pierre Schatzmann Peron*

\begin{abstract}
Viral infections have long been the cause of severe diseases to humans, increasing morbidity and mortality rates worldwide, either in rich or poor countries. Yellow fever virus, H1N1 virus, HIV, dengue virus, hepatitis B and C are well known threats to human health, being responsible for many million deaths annually, associated to a huge economic and social cost. In this context, a recently introduced flavivirus in South America, called Zika virus (ZIKV), led the WHO to declare in February 1st 2016 a warning on Public Health Emergency of International Concern (PHEIC). ZIKV is an arbovirus of the Flaviviridae family firstly isolated from sentinels Rhesus sp. monkeys at the Ziika forest in Uganda, Africa, in 1947. Lately, the virus has well adapted to the worldwide spread Aedes aegypti mosquito, the vector for DENV, CHIKV, YFV and many others. At first, it was not considered a threat to human health, but everything changed when a skyrocketing number of babies born with microcephaly and adults with Guillain-Barré syndrome were reported, mainly in northeastern Brazil. It is now well established that the virus is responsible for the so called congenital Zika syndrome (CZS), whose most dramatic features are microcephaly, arthrogryposis and ocular damage. Thus, in this review, we provide a brief discussion of these main clinical aspects of the CZS, correlating them with the experimental animal models described so far.
\end{abstract}

Keywords: Zika virus, Congenital infection, Arthrogryposis, Ocular abnormality, Experimental models

\section{Background}

Since the first semester of 2015, Brazil has experienced some unprecedented epidemics of babies born with microcephaly as well as of adults with peripheral flaccid paralysis, suggestive of Guillain-Barré syndrome (GBS). The first cases were detected in the states of Bahia, Pernambuco and Paraíba, which are still now the epicenter of the crisis. Although many possibilities were considered, it is now well established that both are caused by a recently introduced virus named Zika virus (ZIKV) [1-4].

The ZIKV is an arbovirus that belongs to the Flaviviridae family. It was first isolated from sentinels Rhesus sp. monkeys from the Ziika forest in Uganda, Africa, in 1947 [5]. Further, the virus was also isolated from the sylvatic vector, a mosquito of Aedes africanus species. Interestingly, the virus has well adapted to other species of mosquitoes, but most importantly to Aedes aegypti [6], widely spread through the globe, and a well-known vector for

\section{- Correspondence: jeanpierre@usp.br}

Neuroimmune Interactions Laboratory, Immunology Department - ICB N, University of Săo Paulo (USP), Av. Prof. Lineu Prestes, 1730, Cidade Universitária, Såo Paulo, SP CEP 05508-900, Brazil many other viruses, including dengue (DENV), West Nile (WNV), yellow fever (YFV), chikungunya (CHV), Japanese encephalitis (JEV) and many others $[7,8]$.

ZIKV genome is composed of a positive single-stranded RNA that codifies three structural proteins, capside (C), pre-membrane (Pr-M) and envelope (Env), and seven non-structural proteins, NS1, NS2a-2b, NS3, NS4a-4b and NS5 [9]. The biological function of these proteins, either in the invertebrate or in vertebrate hosts have just started to be elucidated. Whereas structural proteins are important molecules for cell invasion [10-12], and to induce the immune response, non-structural proteins are important for viral replication and immune response evasion [13, 14]. Recently, it was shown that ZIKV infectivity of $\mathrm{Ae}$ des aegypti depends on NS1 antigenemia. Interestingly, the Asian strain is much more infectious to mosquitoes than the African strain, mainly due to an alanine-tovaline amino acid substitution at the residue 188 of the NS1 [15].

Although ZIKV is considered an emerging infectious disease, it has been neglected for many years since human infection was early reported in Africa and Asia 